\title{
AGR-2 Loose Particle Heating Tests in the Furnace for Irradiated TRISO Testing
}

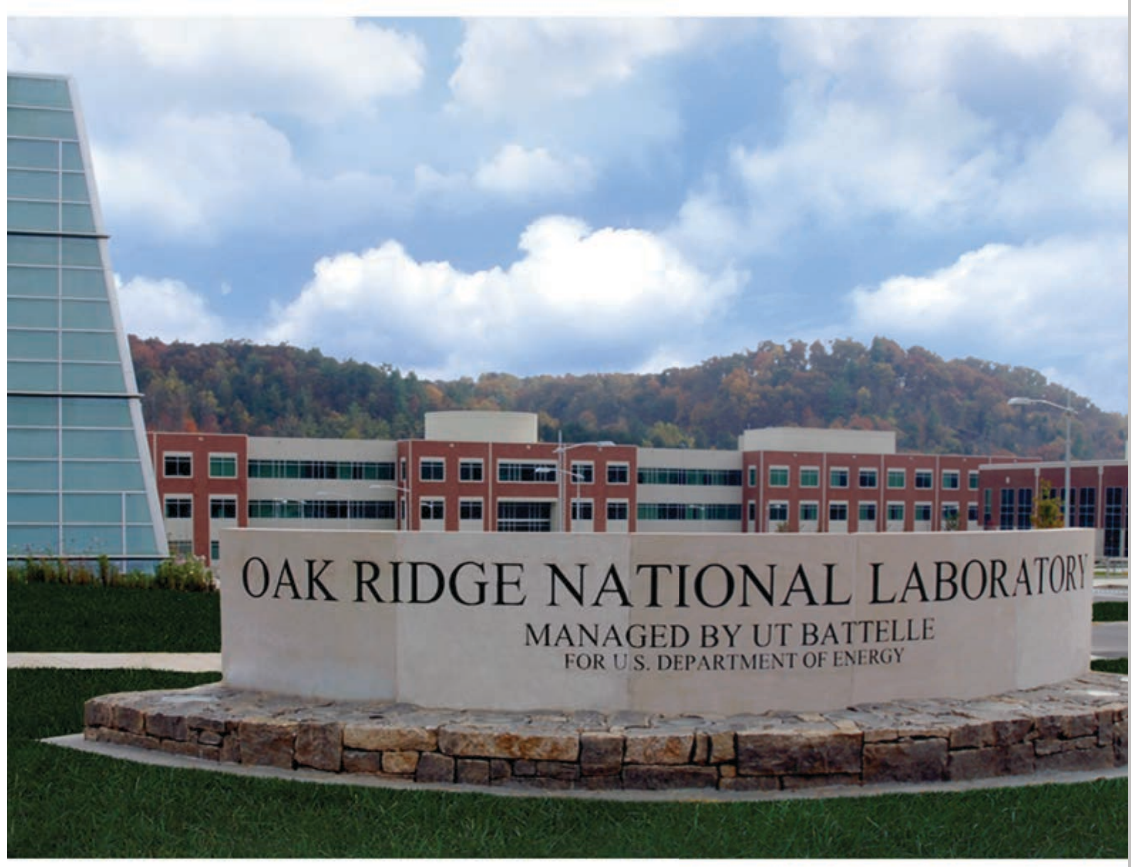

Tyler J. Gerczak Zachary M. Burns Darren J. Skitt Robert N. Morris John D. Hunn

September 2020

Approved for public release. 


\title{
DOCUMENT AVAILABILITY
}

Reports produced after January 1, 1996, are generally available free via US Department of Energy (DOE) SciTech Connect.

Website www.osti.gov

Reports produced before January 1, 1996, may be purchased by members of the public from the following source:

\author{
National Technical Information Service \\ 5285 Port Royal Road \\ Springfield, VA 22161 \\ Telephone 703-605-6000 (1-800-553-6847) \\ TDD 703-487-4639 \\ Fax 703-605-6900 \\ E-mail info@ntis.gov \\ Website http://classic.ntis.gov/
}

Reports are available to DOE employees, DOE contractors, Energy Technology Data Exchange representatives, and International Nuclear Information System representatives from the following source:

Office of Scientific and Technical Information

PO Box 62

Oak Ridge, TN 37831

Telephone 865-576-8401

Fax 865-576-5728

E-mail reports@osti.gov

Website http://www.osti.gov/contact.html

This report was prepared as an account of work sponsored by an
agency of the United States Government. Neither the United States
Government nor any agency thereof, nor any of their employees, makes
any warranty, express or implied, or assumes any legal liability or
responsibility for the accuracy, completeness, or usefulness of any
information, apparatus, product, or process disclosed, or represents that
its use would not infringe privately owned rights. Reference herein to
any specific commercial product, process, or service by trade name,
trademark, manufacturer, or otherwise, does not necessarily constitute
or imply its endorsement, recommendation, or favoring by the United
States Government or any agency thereof. The views and opinions of
authors expressed herein do not necessarily state or reflect those of the
United States Government or any agency thereof. 
Reactor and Nuclear Systems Division

\title{
AGR-2 LOOSE PARTICLE HEATING TESTS IN THE FURNACE FOR IRRADIATED TRISO TESTING
}

\author{
Tyler J. Gerczak \\ Zachary M. Burns \\ Darren J. Skitt \\ Robert N. Morris \\ John D. Hunn
}

Date Published: September 2020

\author{
Prepared by \\ OAK RIDGE NATIONAL LABORATORY \\ Oak Ridge, TN 37831-6283 \\ managed by \\ UT-BATTELLE, LLC \\ for the \\ US DEPARTMENT OF ENERGY \\ under contract DE-AC05-00OR22725
}





\section{CONTENTS}

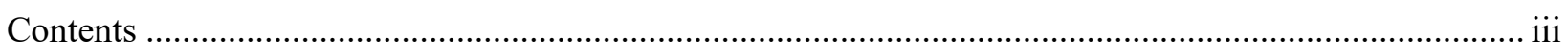

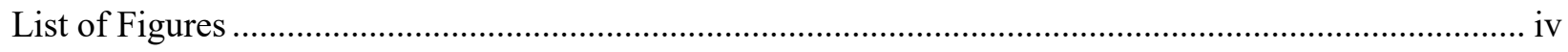

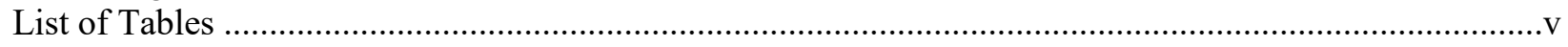

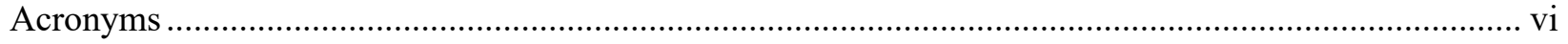

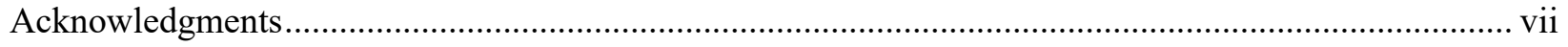

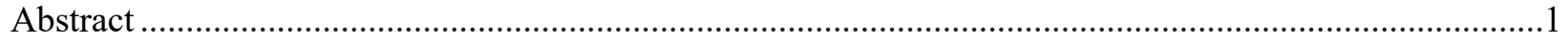

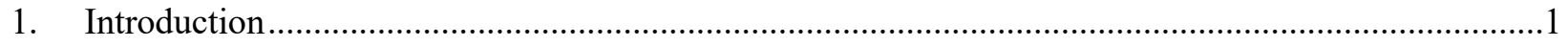

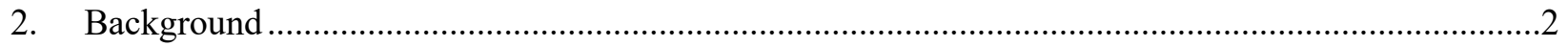

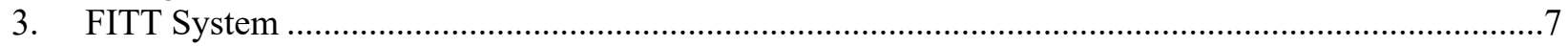

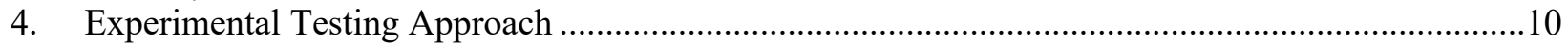

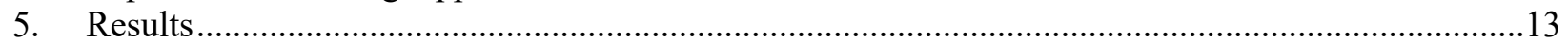

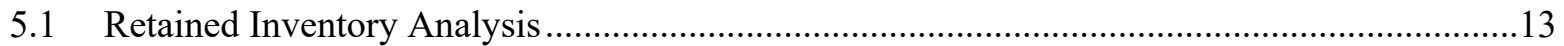

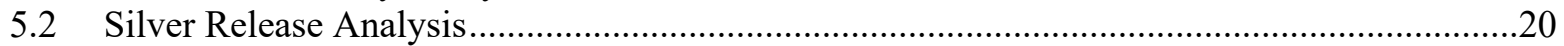

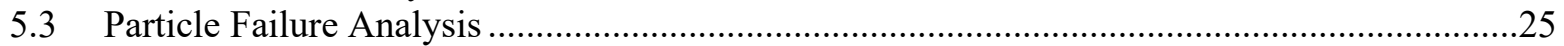

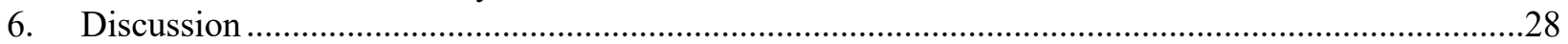

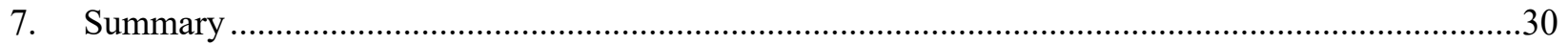

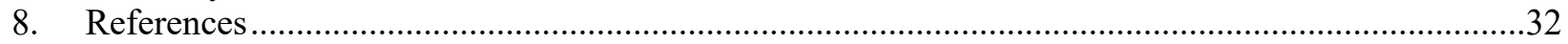




\section{LIST OF FIGURES}

Figure 1. Release rate as a function of time for $1,600^{\circ} \mathrm{C}$ and $1,800^{\circ} \mathrm{C}$ (Morris et al. 2014),.....................3

Figure 2. ${ }^{110 \mathrm{~m}} \mathrm{Ag}$ deposition cup collection rate for AGR-1 Compact 4-2-2 (Hunn et al. 2015a).................6

Figure 3. ${ }^{110 \mathrm{~m}} \mathrm{Ag}$ fractional release rate for AGR-2 CCCTF transient safety test (Hunn et al. 2019)..........6

Figure 4. Photograph of FITT1 with system components identified. .......................................................

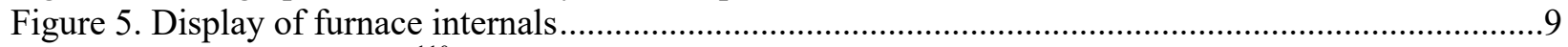

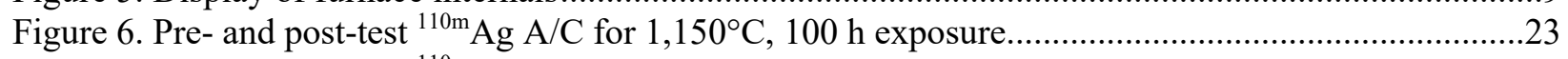

Figure 7. Pre- and post-test ${ }^{110 \mathrm{~m}} \mathrm{Ag} \mathrm{A} / \mathrm{C}$ for $1,150^{\circ} \mathrm{C}, 500 \mathrm{~h}$ exposure, red bars identify $\mathrm{L}_{\mathrm{Q}}$ range................24

Figure 8. Pre- and post-test ${ }^{110 \mathrm{~m}} \mathrm{Ag} \mathrm{A} / \mathrm{C}$ for $1,300^{\circ} \mathrm{C}, 100 \mathrm{~h}$ exposure..................................................24

Figure 9. Pre- and post-test ${ }^{110 \mathrm{~m}} \mathrm{Ag} \mathrm{A} / \mathrm{C}$ for $1,300^{\circ} \mathrm{C}, 500 \mathrm{~h}$ exposure, black and red bars identify $\mathrm{L}_{\mathrm{Q}}$ range for pre-test and post-test respectively.

Figure 10. Particle failures as function of run sequence, orange filled data points represent tests with

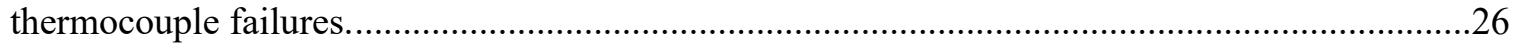

Figure 11. Schematic of particle loading guide system which nests over the graphite holder ...................27

Figure 12. Photograph of post-test particles from $1,600^{\circ} \mathrm{C}, 84 \mathrm{~h}$ run (left) and $1,300^{\circ} \mathrm{C}, 1,500 \mathrm{~h}$ run (right)

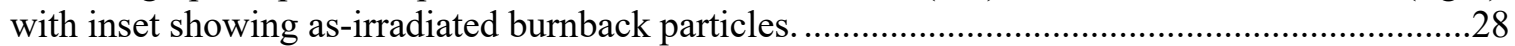




\section{LIST OF TABLES}

Table 1. Estimated $D$ for ${ }^{110 \mathrm{~m}} \mathrm{Ag}$ in $\mathrm{SiC}$ at $1,500-1,700^{\circ} \mathrm{C}$ based on reported $Q$ and associated breakthrough times $\left(t_{0}\right)$

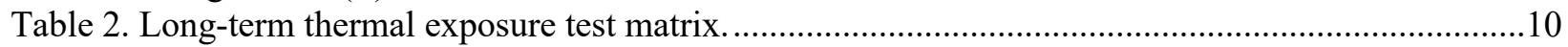

Table 3. Pre- and post-test $\mathrm{A} / \mathrm{C}$ analysis for $1,150^{\circ} \mathrm{C}, 100 \mathrm{~h}$ FITT run ..................................................14

Table 4. Pre- and post-test $\mathrm{A} / \mathrm{C}$ analysis for $1,150^{\circ} \mathrm{C}, 500 \mathrm{~h}$ FITT run .................................................14

Table 5. Pre- and post-test A/C analysis for $1,150^{\circ} \mathrm{C}, 1,000 \mathrm{~h}$ FITT run ...............................................15

Table 6. Pre- and post-test A/C analysis for $1,150^{\circ} \mathrm{C}, 1,500 \mathrm{~h}$ FITT run ................................................15

Table 7. Pre- and post-test $A_{i}$ analysis for $1,300^{\circ} \mathrm{C}, 100 \mathrm{~h}$ FITT run .....................................................17

Table 8. Pre- and post-test $A_{i}$ analysis for $1,300^{\circ} \mathrm{C}$, $500 \mathrm{~h}$ FITT run ....................................................17

Table 9. Pre- and post-test $A_{i}$ analysis for $1,300^{\circ} \mathrm{C}, 985 \mathrm{~h}$ FITT run ....................................................18

Table 10. Pre- and post-test $A_{i}$ analysis for $1,300^{\circ} \mathrm{C}, 1,500 \mathrm{~h}$ FITT run ................................................18

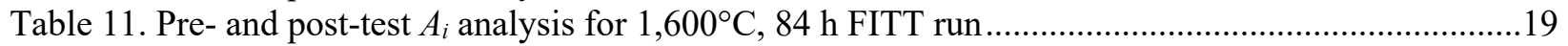

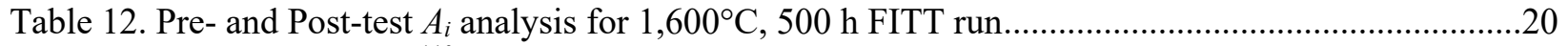

Table 13. Pre- and post-test ${ }^{110 \mathrm{~m}} \mathrm{Ag} A_{i}$ and $\mathrm{A} / \mathrm{C}$ analysis for $1,150^{\circ} \mathrm{C}, 100 \mathrm{~h}$ FITT run............................21

Table 14. Pre- and post-test ${ }^{110 \mathrm{~m}} \mathrm{Ag} A_{i}$ and $\mathrm{A} / \mathrm{C}$ analysis for $1,150^{\circ} \mathrm{C}, 500 \mathrm{~h}$ FITT run............................21

Table 15. Pre- and post-test ${ }^{110 \mathrm{~m}} \mathrm{Ag} A_{i}$ and $\mathrm{A} / \mathrm{C}$ analysis for $1,300^{\circ} \mathrm{C}, 100 \mathrm{~h}$ FITT run...........................22

Table 16. Pre- and post-test ${ }^{110 \mathrm{~m}} \mathrm{Ag} A_{i}$ and $\mathrm{A} / \mathrm{C}$ analysis for $1,300^{\circ} \mathrm{C}, 500 \mathrm{~h}$ FITT run.............................22

Table 17. Number of failed particles for each test condition..................................................................25 


\section{ACRONYMS}

AGR

CCCTF

FACS

FITT

DOE

IFEL

IMGA

INL

$\mathrm{L}_{\mathrm{Q}}$

$\mathrm{M} / \mathrm{A}$

M/AA

$\mathrm{M} / \mathrm{C}$

MDL

$\mathrm{OPyC}$

ORNL

PIE

$\mathrm{SiC}$

TRISO

UHP
Advanced Gas Reactor (Fuel Development and Qualification Program)

Core Conduction Cooldown Test Facility

Fuel Accident Condition Simulator

Furnace for Irradiated TRISO Testing

US Department of Energy

Irradiated Fuels Examination Laboratory

Irradiated Microsphere Gamma Analyzer

Idaho National Laboratory

minimum quantifiable limit

measured vs. average

measured vs. adjusted average

measured vs. calculated

minimum detection limit

outer pyrolytic carbon

Oak Ridge National Laboratory

postirradiation examination

silicon carbide (TRISO layer)

tristructural-isotropic (coated particles)

ultra-high purity 


\section{ACKNOWLEDGMENTS}

This work was sponsored by the US Department of Energy Office of Nuclear Energy Advanced Reactor Technologies as part of the Advanced Gas Reactor Fuel Development and Qualification Program. Hot cell activities were supported by Oak Ridge National Laboratory (ORNL) Irradiated Fuels Examination Laboratory staff. 


\begin{abstract}
A furnace system was developed to thermally expose individual tristructural-isotropic (TRISO) coated particles to expand upon established postirradiation examination (PIE) safety testing that is used to explore particle failures and fission product release from compacts. Two systems were installed in the Irradiated Fuels Examination Facility (IFEL) at Oak Ridge National Laboratory (ORNL). The targeted design was intended to be simple and flexible to allow a range in conditions to be explored. Initial inert atmosphere testing indicated the presence of particle failures, so modifications to the testing approach were implemented to improve the furnace operation. Ultimately, burnback particles were analyzed to provide a direct measurement of fission product release, thus avoiding the complications from integral release that were observed during whole compact testing. Particles were exposed to temperatures ranging $1,150-1,300^{\circ} \mathrm{C}$ for up to $1,500 \mathrm{~h}$ and $1,600^{\circ} \mathrm{C}$ up to $500 \mathrm{~h}$. No indication of uniform release of fission products such as ${ }^{106} \mathrm{Ru},{ }^{125} \mathrm{Sb}$, or ${ }^{154} \mathrm{Eu}$ was observed, however, indication of particle dependent ${ }^{154} \mathrm{Eu}$ release was suggested for select particles. Exploration of ${ }^{110 \mathrm{~m}} \mathrm{Ag}$ release was limited to $1,150^{\circ} \mathrm{C}$ and $1,300^{\circ} \mathrm{C}$ up to $500 \mathrm{~h}$. The analysis indicated that there was nonuniform release of ${ }^{110 \mathrm{~m}} \mathrm{Ag}$ and supports a possible bimodal temperature dependence on silver release.
\end{abstract}

\title{
1. INTRODUCTION
}

The release of radionuclides from tristructural-isotropic (TRISO) coated particle fuel is an import metric for fuel performance. The release of certain radionuclides such as ${ }^{110 \mathrm{~m}} \mathrm{Ag}$ is relevant concerning fuel lifetime and plant maintenance, while other radionuclides such as ${ }^{90} \mathrm{Sr}$ are biologically relevant. It is necessary to understand the release of radionuclides over a wide range of thermal conditions to accurately predict the release of radionuclides, to gain insights into the active release mechanism, and to support the development of mitigation strategies.

The US Department of Energy's Advanced Gas Reactor Fuel Qualification and Development (AGR) Program has undertaken a comprehensive effort to re-establish domestic TRISO fuel expertise and capability. The program includes fuel fabrication, irradiation testing, and postirradiation examination (PIE) for seven irradiation experiments designated AGR-1 through AGR-7 (Petti et al. 2010). One aspect of the PIE effort focused on tracking the distribution and concentration of relevant radionuclides from the capsule to the individual particle level, as well as quantifying the number of particle failures (Demkowicz et al. 2015b). Compacts were subjected to safety testing at elevated temperatures to analyze radionuclide release and particle failure rates at temperatures and times relevant to accident conditions and beyond (Hunn et al. 2018a, Morris et al. 2014, Morris et al. 2016).

The safety testing occurred in two high-temperature furnace systems located in radiological containment structures that were specially designed for safety testing within the AGR program: the Core Conduction Cooldown Test Facility (CCCTF) at Oak Ridge National Laboratory (ORNL) (Baldwin et al. 2012), and the Fuel Accident Condition Simulator (FACS) at Idaho National Laboratory (INL) (Demkowicz et al. 2015a). Both systems have online fission gas measurements and cold traps for measuring time-dependent release of volatile fission products evolved from the compacts.

The safety testing systems are leveraged to provide qualification support by measuring radionuclide release rates and providing information on particle failure identification for a statistically relevant population of particles. Typical safety testing runs in the CCCTF are $1,600-1,800^{\circ} \mathrm{C}$ for $300 \mathrm{~h}$ with periodic (usually $24 \mathrm{~h}$ ) exchanges of the deposition cup to measure time-dependent release of volatile radionuclides. The CCCTF system undergoes regular maintenance, and furnace internals are replaced as required to maintain low background and to limit cross contamination between specific exposures. These 
CCCTF experiments are conducted in a stand-alone hot cell in the Irradiated Fuels Examination Laboratory (IFEL) at ORNL, and they require hot cell operator support.

The need for sampling a large population of particles during safety testing and the complexity of the safety testing systems' operation does not present a practical opportunity to further explore non-standard safety testing conditions and to expand on safety testing results. However, nonstandard CCCTF and FACS tests have been performed, such as transient tests (Stempien et al. 2016), step-wise temperature variation (Hunn et al. 2015a), and loose particle tests (Hunn et al. 2015b). These tests have presented unique fission product release behaviors that warrant additional study. A simple, flexible, low-cost thermal exposure system, the Furnace for Irradiated TRISO Testing (FITT), was developed to expand the thermal testing envelope of irradiated TRISO particles without interrupting CCCTF and FACS schedules implemented to support qualification.

\section{BACKGROUND}

A holistic understanding of fission product and actinide release is obtained through analyses ranging over multiple length scales, from the capsule components to individual compacts, to the matrix, and finally, to the individual particle level. Both gamma analysis and analytical chemistry techniques are leveraged to measure the relative concentration of specific species on each level of analysis. The complete analysis suite is destructive, as some components are oxidized and acid leached to dissolve fission products and actinides for analytical chemistry mass spectroscopy, whereas individual particles are isolated by deconsolidating the compact matrix material (as-irradiated or after safety testing). This comprehensive, step-wise analysis provides a picture of the distribution and release of radionuclides after irradiation and after safety testing. A detailed overview of this comprehensive PIE approach was reported for AGR-1 Compact 4-4-2 PIE (Hunn et al. 2013), and detailed discussions about safety testing and irradiated microsphere gamma analyzer (IMGA) examination, which is used to measure individual particle activity, are discussed in Baldwin et al. (Baldwin et al. 2012).

The measurement of release of radioisotopes during safety testing is an integral measurement of fission products and actinides evolved from the whole compact. Measured release can be sourced from multiple parallel mechanisms. One source of measured release comes from fission products and actinides present in the graphite material outside the $\mathrm{SiC}$ layer of the TRISO particles at the start of safety testing: that is, in the compact matrix and in the outer pyrolytic carbon (OPyC) layer. Through-layer release during safety testing is also possible. In safety tests at $1,800^{\circ} \mathrm{C}$ after $\sim 70-100 \mathrm{~h}$, indication of additional through-layer release of ${ }^{110 \mathrm{~m}} \mathrm{Ag}$ from intact particles is suggested: that is, release of radionuclides present in the $\mathrm{SiC}$ barrier layer and internal to the $\mathrm{SiC}$ barrier layer prior to the start of safety testing (Morris et al. 2014). However, the signatures of through-layer release can be masked by (1) the nature of the integral release due to slow release of the radionuclides present in the matrix and pyrocarbon outside the SiC layer of the TRISO particle prior to safety testing or (2) excess release from failed particles.

Examples of the ${ }^{110 \mathrm{~m}} \mathrm{Ag}$ fractional release curves from AGR-1 1,600 and $1,800^{\circ} \mathrm{C}$ safety tests are shown in Figure 1. There is confidence in the observation of the additional release of silver at $1,800^{\circ} \mathrm{C}$, as the silver present in the graphite outside of the SiC layer of the TRISO particles is rapidly released from the compact upon reaching targeted safety testing temperatures as indicated by an initial jump to a fractional release value associated with silver outside of the $\mathrm{SiC}$ layer and additional release from the compact indicated by an increase in fractional release after $\sim 70-100 \mathrm{~h}$. No indication of release at $1,600^{\circ} \mathrm{C}$ is observed as after the initial jump to a fraction release associated with silver outside of the $\mathrm{SiC}$ layer no increase in fractional release is observed over the course of the safety test. Additional through-layer release of europium and strontium is also suggested after $\sim 140-155 \mathrm{~h}$ (Morris et al. 2014). However, unlike the silver, the release of europium and strontium is gradual at safety testing temperatures. This is 
expected to be due to slower diffusion kinetics in relevant graphite phases, since both strontium and europium form a carbide phase. Through-layer release of ${ }^{110 \mathrm{~m}} \mathrm{Ag}$ and ${ }^{154} \mathrm{Eu}$ were also confirmed from full TRISO particles subjected to loose particle safety testing at $1,800^{\circ} \mathrm{C}, 600 \mathrm{~h}$ where similar release behaviors for silver compared to whole compact safety testing were observed (Hunn et al. 2013).
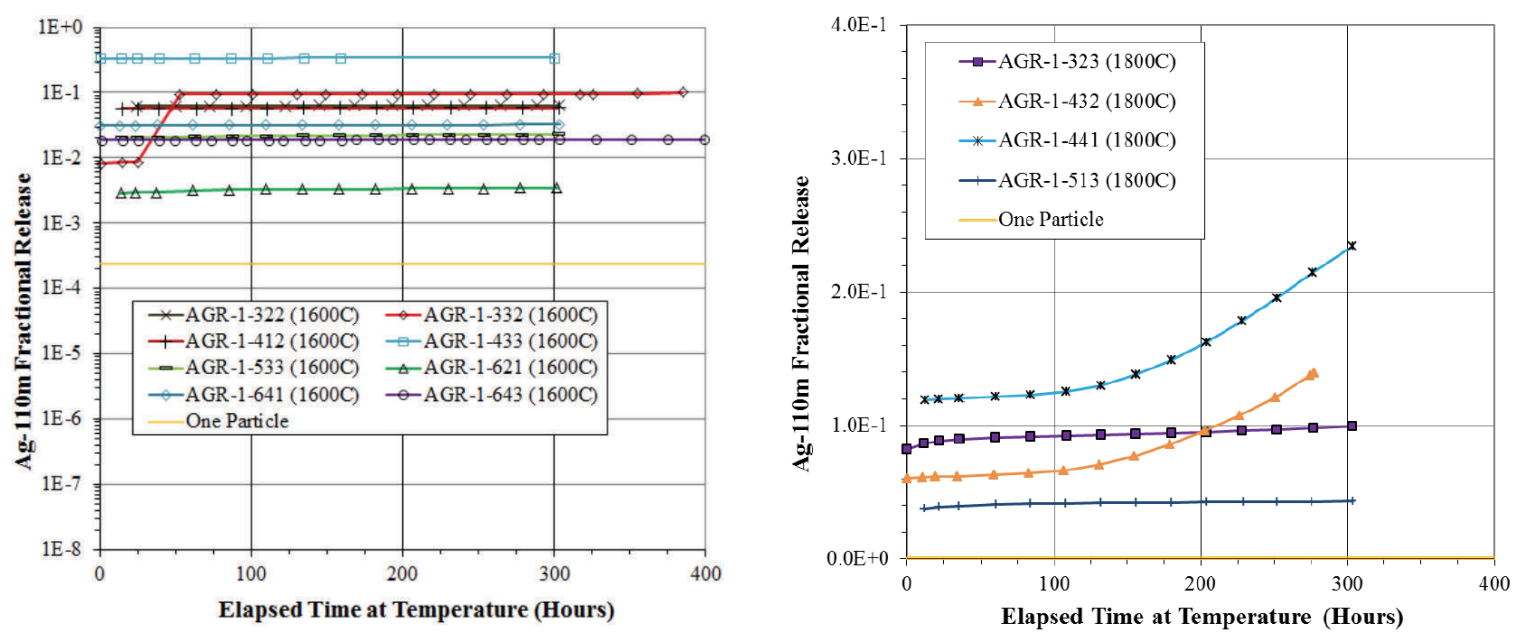

Figure 1. Release rate as a function of time for $1,600^{\circ} \mathrm{C}$ and $1,800^{\circ} \mathrm{C}$ (Morris et al. 2014).

Comparison of the release behavior at $1,800^{\circ} \mathrm{C}$ for AGR-1 compacts showed that through-layer release was dependent on the SiC microstructure (Gerczak et al. 2016). Through-layer release was observed for ${ }^{110 \mathrm{~m}} \mathrm{Ag},{ }^{154} \mathrm{Eu}$, and ${ }^{90} \mathrm{Sr}$ only in the fine-grained variant 3 (AGR-1-432 and AGR-1-441 in Figure 1), with no clear release in the larger grain baseline and variant 1 compacts (AGR-1-323 and AGR-1-513 in Figure 1). Through-layer release was observed for AGR-2 $1,800^{\circ} \mathrm{C}$ safety tests, as well, which was expected, as they possess fine-grained $\mathrm{SiC}$ microstructures similar to the AGR-1 variant 3 (Morris et al. 2014, Gerczak et al. 2016). Diffusive release is a kinetic process, and the microstructural dependence indicates that the release behaviors at elevated safety testing temperature support a grain boundary diffusion mechanism at $1,800^{\circ} \mathrm{C}$. No clear observation of through-layer release was observed for lower temperature safety tests at 1,600 and $1,700^{\circ} \mathrm{C}$. Because the release observed at $1,800^{\circ} \mathrm{C}$ is likely due to grain boundary diffusion and is a kinetic process, longer thermal annealing times would be required to observe continued through-layer release.

Accurate diffusion coefficients are needed to best predict release of fission products and radionuclides from TRISO fuel. Diffusion coefficients obtained from release measurements from TRISO fuel have been reported for many fission product systems in $\mathrm{SiC}$; however, considerable variability was observed for the reported diffusion coefficients (IAEA 1997). The variability is likely impacted by differences in the $\mathrm{SiC}$ layer microstructure (Petti et al. 2002), which is supported by the observation from AGR-1 safety testing between the different $\mathrm{SiC}$ variants (Gerczak et al. 2016). The difference between AGR-1 variants highlights the need to measure release kinetics on well-characterized, representative TRISO fuel systems.

Estimates of the diffusivity of specific fission products from AGR UCO TRISO fuel can be made from observed releases during safety testing. The time to establish steady-state, through-layer release $\left(t_{0}\right)$ is estimated by Bullock (Bullock 1984) to follow the relationship presented in Eq. (1), in which $x$ is the thickness of the $\mathrm{SiC}$ layer, and $D$ is the temperature-dependent diffusion coefficient in the $\mathrm{SiC}$ layer.

$$
t_{0}=\frac{x^{2}}{6 D}
$$


The observed through-layer release of ${ }^{110 \mathrm{~m}} \mathrm{Ag}$ and ${ }^{154} \mathrm{Eu}$ from AGR-1 variant 3 compacts results in estimated ranges in $D$ of $5.7-8.1 \times 10^{-16} \mathrm{~m}^{2} / \mathrm{s}$ and $3.7-4.1 \times 10^{-16} \mathrm{~m}^{2} / \mathrm{s}$ at $1,800^{\circ} \mathrm{C}$ for ${ }^{110 \mathrm{~m}} \mathrm{Ag}$ and ${ }^{154} \mathrm{Eu}$, respectively. Based on the relationship described in Eq. (1), observations of additional through-layer release would only be observed for fission product and actinide species with diffusion coefficients greater than $\sim 1.9 \times 10^{-16} \mathrm{~m}^{2} / \mathrm{s}$ after any $300 \mathrm{~h}$ safety test. The temperature-dependent diffusion coefficients follow an Arrhenius relationship, as indicated in Eq. (2), in which $D_{0}$ is the pre-exponential term $\left(\mathrm{m}^{2} / \mathrm{s}\right)$, Q is the activation energy $(\mathrm{eV}), \mathrm{k}$ is Boltzmann's constant $(\mathrm{eV} / \mathrm{K})$, and $T$ is temperature $(\mathrm{K})$.

$$
D(T)=D_{0} \exp \left(\frac{-Q}{k T}\right)
$$

Values for $D(T)$ of AGR pedigree fuel at the lower safety testing temperatures $\left(1,600-1,700^{\circ} \mathrm{C}\right)$ can be estimated using reported activation energies $(Q)$ for diffusive release from irradiated TRISO particles, in conjunction with the estimated diffusion coefficients from break-through times at $1,800^{\circ} \mathrm{C}$, to calculate $D_{0}$ in Eq. (2). The activation energies reported here represent the general range in reported values for silver release from TRISO fuel (IAEA 1997, Nabielek et al. 1977, Bullock 1984). Based on these estimated breakthrough times (Table 1), no additional release of silver would be expected to be observed at the lower temperature safety tests at $1,600-1,700^{\circ} \mathrm{C}$ for the upper bound $Q(4.22 \mathrm{eV})$, whereas release may be observed for the lower bound Q $(2.21 \mathrm{eV})$. Because no additional silver release was observed at $1,700^{\circ} \mathrm{C}$, $300 \mathrm{~h}$ safety tests, it is likely that $\mathrm{D}\left(\leq 1,700^{\circ} \mathrm{C}\right)$ is less than $\sim 1.9 \times 10^{-16} \mathrm{~m}^{2} / \mathrm{s}$. This reflects an activation energy that is likely closer towards the reported upper bound value of $4.22 \mathrm{eV}$.

Table 1. Estimated $D$ for ${ }^{110 \mathrm{~m}} \mathrm{Ag}$ in $\mathrm{SiC}$ at $1,500-1,700^{\circ} \mathrm{C}$ based on reported $Q$ and associated break-through times $\left(t_{0}\right)$

\begin{tabular}{c|cc|cc}
\hline & \multicolumn{2}{c}{$\mathbf{Q}=\mathbf{2 . 2 1} \mathbf{~ e V}($ Nabielek et al. 1977) } & \multicolumn{2}{c}{$\mathbf{Q}=\mathbf{4 . 2 2}$ eV (Bullock 1984) } \\
\hline & $D(T) \mathrm{m}^{2} / \mathrm{s}$ & $t_{0}(\mathrm{~h})$ & $D(T) \mathrm{m}^{2} / \mathrm{s}$ & $t_{0}(\mathrm{~h})$ \\
$1,500^{\circ} \mathrm{C}$ & $7.0 \times 10^{-17}$ & 811 & $1.0 \times 10^{-17}$ & 5,441 \\
$1,600^{\circ} \mathrm{C}$ & $1.5 \times 10^{-16}$ & 375 & $4.6 \times 10^{-17}$ & 1,246 \\
$1,700^{\circ} \mathrm{C}$ & $3.0 \times 10^{-16}$ & 187 & $1.7 \times 10^{-16}$ & 331 \\
\hline
\end{tabular}

Expanded times and temperatures should be explored beyond those typical of safety testing so that through-layer release can occur and be measured to allow calculation of effective diffusion coefficients. Silver release would be expected to be observed shortly after the typical $300 \mathrm{~h}$ run at $1,700^{\circ} \mathrm{C}$, but significant additional exposure times $\sim 1,000 \mathrm{~h}$ beyond the typical safety testing conditions would be needed to observe silver release at $1,600^{\circ} \mathrm{C}$. Observation of release of carbide formers such as ${ }^{154} \mathrm{Eu}$ and ${ }^{90} \mathrm{Sr}$ is more complicated due to the slow release from the graphite surrounding the particles and limited insight on release kinetics.

One approach to isolating the release of carbide formers is through individual particle testing. The release of europium from intact particles was explored by Bullock on individual sets of 10 particles for various particle types exposed to temperatures $1,200-1,500^{\circ} \mathrm{C}$ for up to $10,000 \mathrm{~h}$ (Bullock 1984). The exposure of individual particle sets removes the possible release from the compact matrix, but does exclude the fission products retained in the $\mathrm{OPyC}$ from the irradiation, which may complicate the interpretation. Release was observed at temperatures as low as $1,200^{\circ} \mathrm{C}$, with break-through times of $\sim 5,200$ and $41 \mathrm{~h}$ at 1,200 and $1,500^{\circ} \mathrm{C}$, respectively for UCO TRISO. Similarly, loose particle testing of TRISO particles in the CCCTF from AGR-1 4-4-2 particles at $1,800^{\circ} \mathrm{C}$ for $650 \mathrm{~h}$ showed release of ${ }^{154} \mathrm{Eu}$ with average release of $\sim-11 \%$ of the ${ }^{154} \mathrm{Eu}$ inventory fraction measured after thermal exposure (Hunn et al. 2015b). These observations support leveraging loose particle testing for measurement of fission product release after out-of-pile 
thermal exposure. Additionally, exploration of particles deconsolidated from individual compacts and subjected to leach-burn-leach with no remaining OPyC layer, defined as "burnback" particles, would provide direct evidence of additional through-layer release through the $\mathrm{SiC}$ layer compared to full TRISO particles, as all radionuclides present in the graphite materials outside of the $\mathrm{SiC}$ layer would be removed.

The use of the IMGA to measure the individual particle fission product inventory before and after thermal exposure was established during individual particle heating tests for AGR-1 Compact 4-4-2 (Hunn et al. 2015b). The IMGA analysis focuses on radioisotopes with convenient gamma signatures, examples are ${ }^{110 \mathrm{~m}} \mathrm{Ag},{ }^{106} \mathrm{Ru},{ }^{125} \mathrm{Sb},{ }^{137} \mathrm{Cs},{ }^{144} \mathrm{Ce}$, and ${ }^{154} \mathrm{Eu}$. The use of IMGA analysis allows the fission products and actinide inventory of a single particle to be measured and tracked. Measuring release at the individual particle level also isolates the contribution to release from just the particle of interest, removing contributions from adjacent particle failures. This allows insight into possible particle-to-particle variation in release behavior. Specifically, uniform release of ${ }^{154} \mathrm{Eu}$ would be expected under classical diffusion conditions (Bullock 1984). As such, combining longer term thermal exposures with individual burnback particle gamma analysis provides direct confirmation of through layer release, as well as insight into the nature of the release mechanism.

Variable release behaviors for silver are expected due to unique temperature-dependent release observations of silver observed during stepwise and transient safety tests, as shown in Figures 2 and 3 (Hunn et al. 2015a, Stempien et al. 2016, Hunn et al. 2019). The elevated release at lower temperatures during transient testing (Figure 3) was observed in both AGR-1 (Stempien et al. 2016) and AGR-2 experiments (Hunn et al. 2019). Specifically, the release of silver does not appear to be proportional to temperature. From both the step-wise and transient testing, a maximum release rate appears to be between $1,000-1,400^{\circ} \mathrm{C}$. This low-temperature maximum release rate suggests that there are multiple active through-layer silver release mechanisms. The active release mechanism at these temperatures, which are closer to in-pile temperatures, may be related to the release observed in-pile. The release also appears to be more rapid relative to the diffusive through-layer release observed at $1,800^{\circ} \mathrm{C}$ based on relative breakthrough times, with additional silver release observed after approximately $24 \mathrm{~h}$. Most silver is expected to be driven from the compact matrix upon reaching initial safety testing temperatures. As such, the relative increase in rate upon reaching a cooler temperature would imply additional through-layer release of silver from the particles. However, the compact level analysis to date remains integral in nature. The overall observation is that silver release follows a bimodal temperature dependence with two different mechanisms being dominant at different temperatures regimes, where one mechanism is responsible for release between $1,000-1,400^{\circ} \mathrm{C}$ and a microstructurally dependent diffusion mechanism controls release at $1,800^{\circ} \mathrm{C}$. 


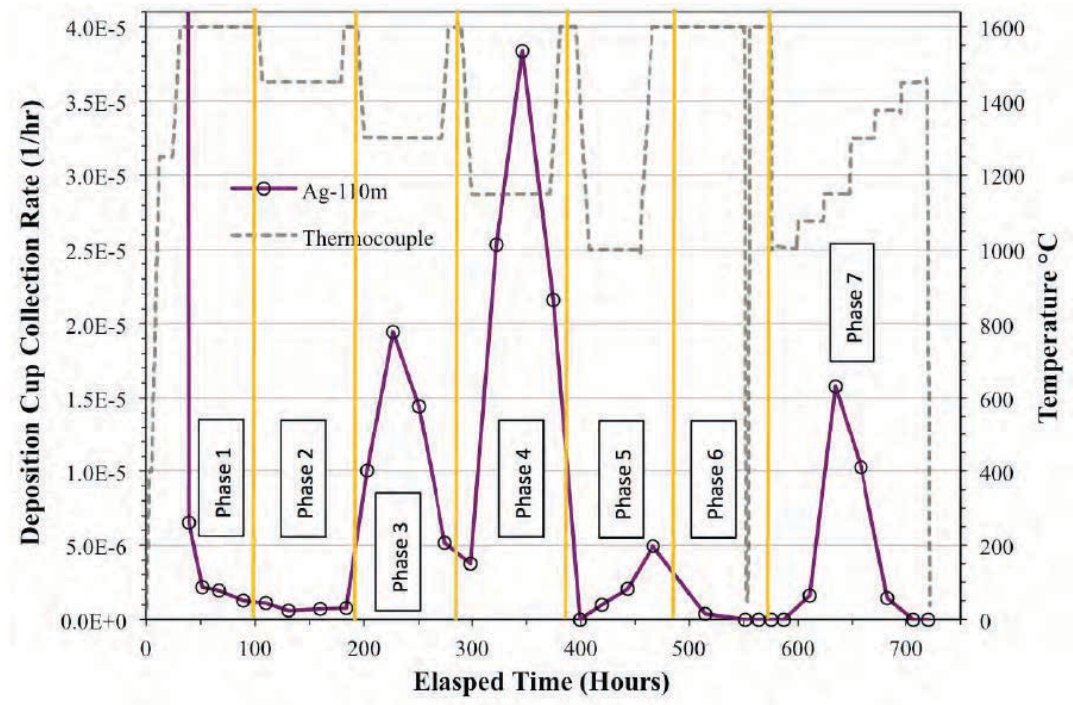

Figure 2. ${ }^{110 \mathrm{~m}}$ Ag deposition cup collection rate for AGR-1 Compact 4-2-2 (Hunn et al. 2015a).

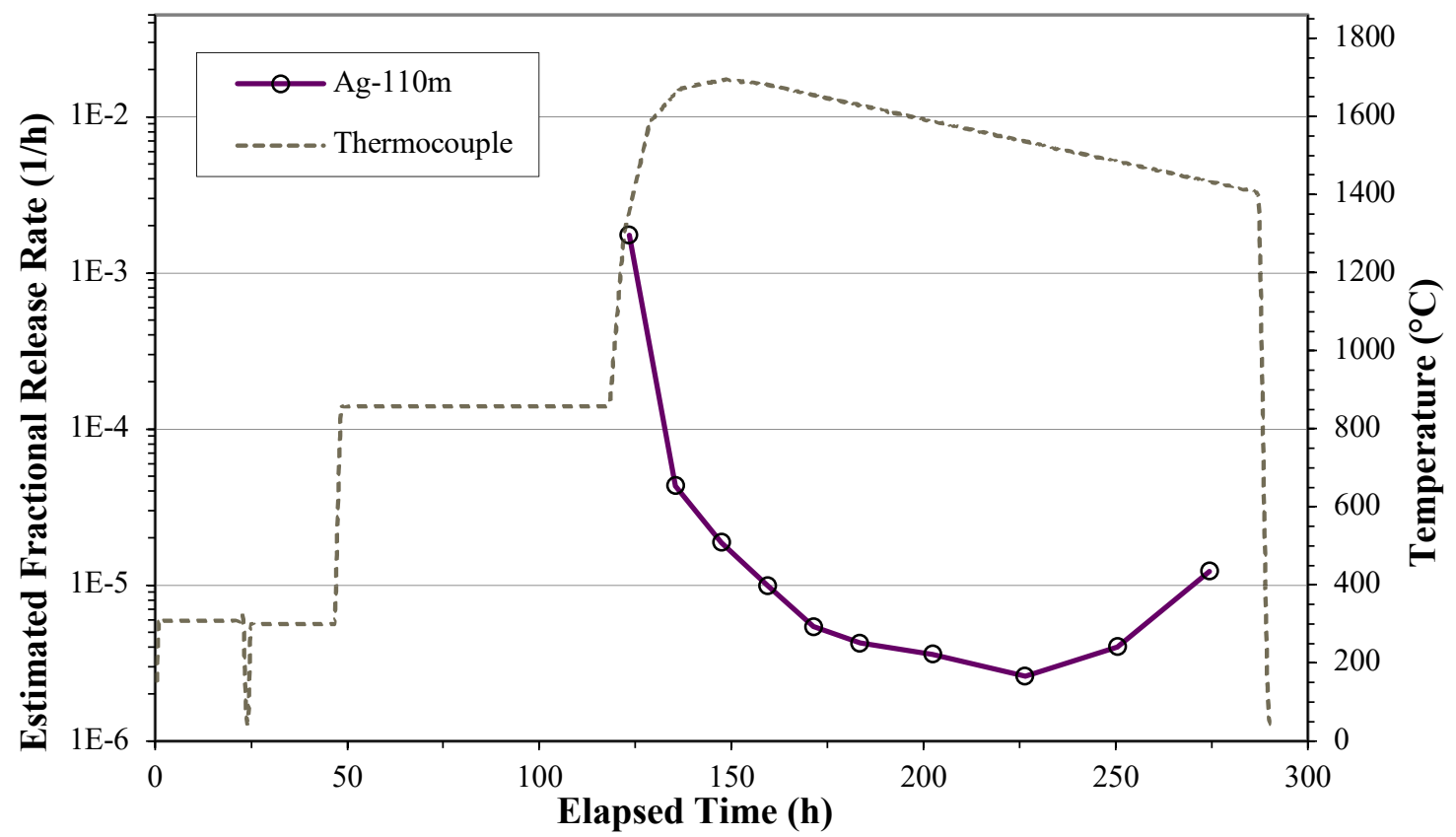

Figure 3. ${ }^{110 \mathrm{~m}} \mathrm{Ag}$ fractional release rate for AGR-2 CCCTF transient safety test (Hunn et al. 2019).

Determination of diffusion kinetics and confirmation of the bimodal release behavior of ${ }^{110 \mathrm{~m}} \mathrm{Ag}$ highlights the need for expanded thermal testing of TRISO fuel particles compared to standard safety testing approaches. Release at safety testing relevant temperatures can be explored, and kinetics can be estimated to support fuel modeling efforts through long-term thermal exposures. Using burnback particles removes the potential hold-up in the OPyC layer for carbide formers (e.g., $\left.{ }^{154} \mathrm{Eu}\right)$, and it yields a direct observation of release. Similarly, isochronal comparisons across different temperatures $\left(1,000-1,600^{\circ} \mathrm{C}\right)$ of burnback particles can identify the potential for multiple active release behaviors and the presence of rapid silver diffusion at "low temperatures." 


\section{3. $\quad$ FITT SYSTEM}

The FITT system is an irradiated TRISO particle furnace system that facilitates long-term thermal exposures of individually tracked particles for conditions beyond the standard scope of safety testing systems. The FITT system was envisioned to be flexible and lower cost to operate relative to the CCCTF and FACS systems. Two duplicate FITT systems, designated FITT1 and FITT2, have been deployed at ORNL to explore long-term individual the release behaviors of TRISO particle fission products beyond traditional safety testing conditions.

The FITT systems are intentionally simple modified box furnaces positioned in a radiological hood in the IFEL at ORNL. The number of particles is kept small in number to reduce the radiological hazards to those that can be managed in this environment. The location allows for convenient material transfer in and out of the primary IFEL hot cells and loading of the furnace. Figure 4 shows a picture of the general furnace set-up. The furnace design consists of a ceramic tube closed on one end (primary furnace tube) positioned in the center of the furnace constant temperature zone through a 2-inch port at the top of the furnace, with an aluminum cooling fin to dissipate heat at the top of the tube. The TRISO particles of interest are positioned in the bottom of the ceramic tube. The system is isolated from the environment through a custom end cap which uses a compression fitting and high-temperature Kalrez ${ }^{\circledR}$ O-rings to form a gas-tight seal. The end cap incorporates a gas supply line and a gas outlet line. The inlet is connected to a roughing pump and compressed gas cylinder bank with a pressure gauge. The outlet line connects to an inline ( $\sim 10 \mathrm{psi})$ pressure relief valve and a needle valve to isolate the system from the exhaust and to allow consecutive pump and purge cycles. Beyond the needle valve is a gas flow meter to control the flow rate out of the furnace internals, condensation coil to condense and trap any potential volatilized fission products, and an inline filter to trap possible particulates. 


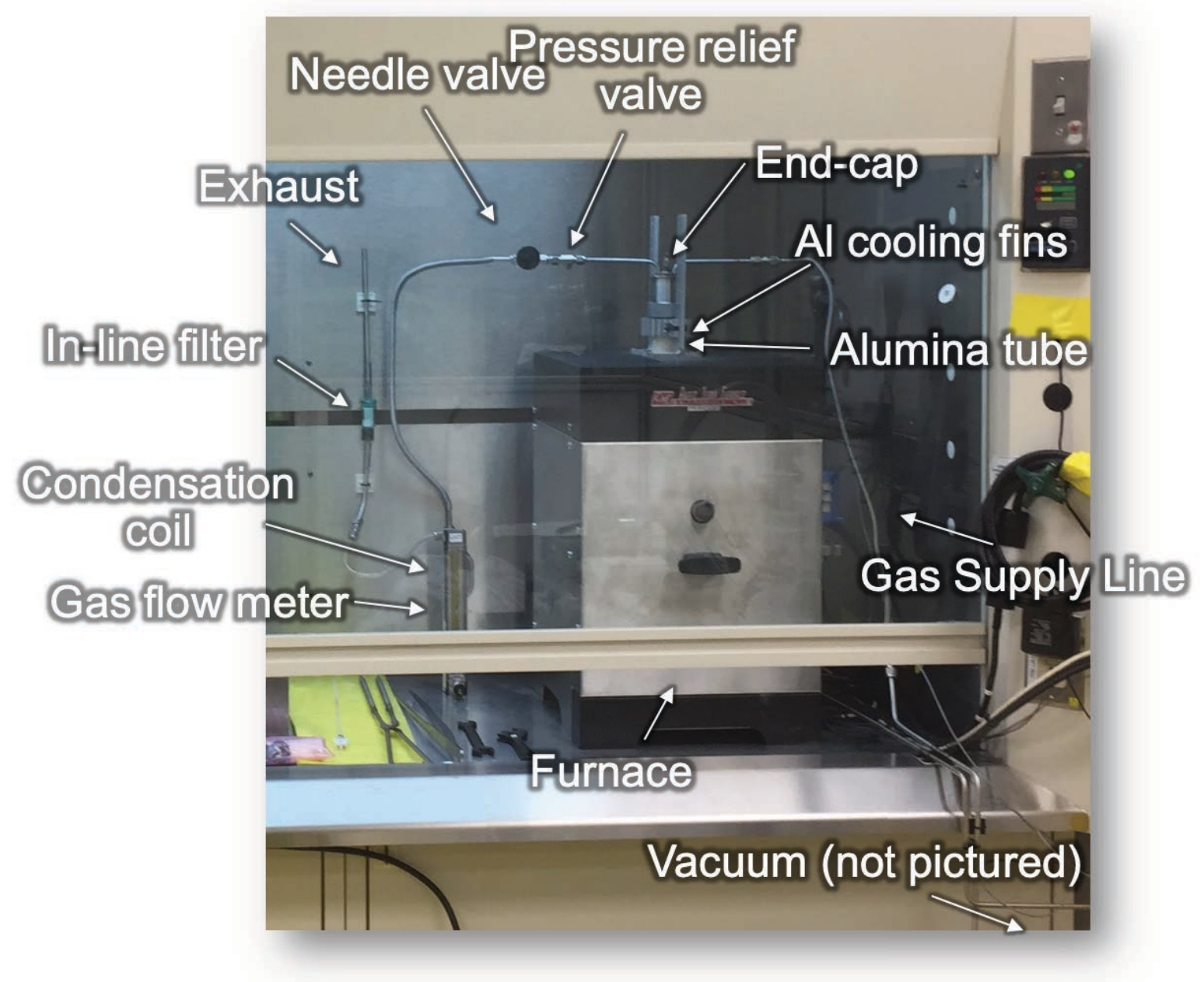

Figure 4. Photograph of FITT1 with system components identified.

The furnace internals are shown in Figure 5. The furnace internals house the individual TRISO particles targeted for testing in a manner that allows the particles to be identified after thermal exposure. The particles are positioned in a graphite holder with ten individual holes positioned in clusters of 2, 3, and 5 . This unique pattern allows for each location to be tracked before and after exposure. The individual number scheme 1-10 is shown in Figure 5. Particles are transferred out of the IMGA hot cell in individually tracked plastic vials, where they are transferred to the graphite holder using vacuum tweezers and dropped into a specially designed funnel system which nests over the sample holder with a slot for locations 1-10. This approach represents the final method for sample transfer. Initially, the transfer process used aluminum vials and tweezers to transfer the particles, but initial high rates of particle failure prompted investigation into particle handling, resulting in new approaches to reduce the overall handling of the particles after burnback. A SiC spacer is positioned above and below the graphite holder containing the particles to provide structural support and act as a sacrificial oxygen getter. The graphite holder is secured in a singular unit by sliding each component onto a threaded graphite bolt and securing the assembly with a graphite nut. This self-contained sample holder is then inserted into a ceramic holder, and a graphite cap is placed on top of the ceramic holder. The unit is placed in the bottom of the primary ceramic tube, and a ceramic insulator is placed on top of the graphite cap housing the sample holder. 


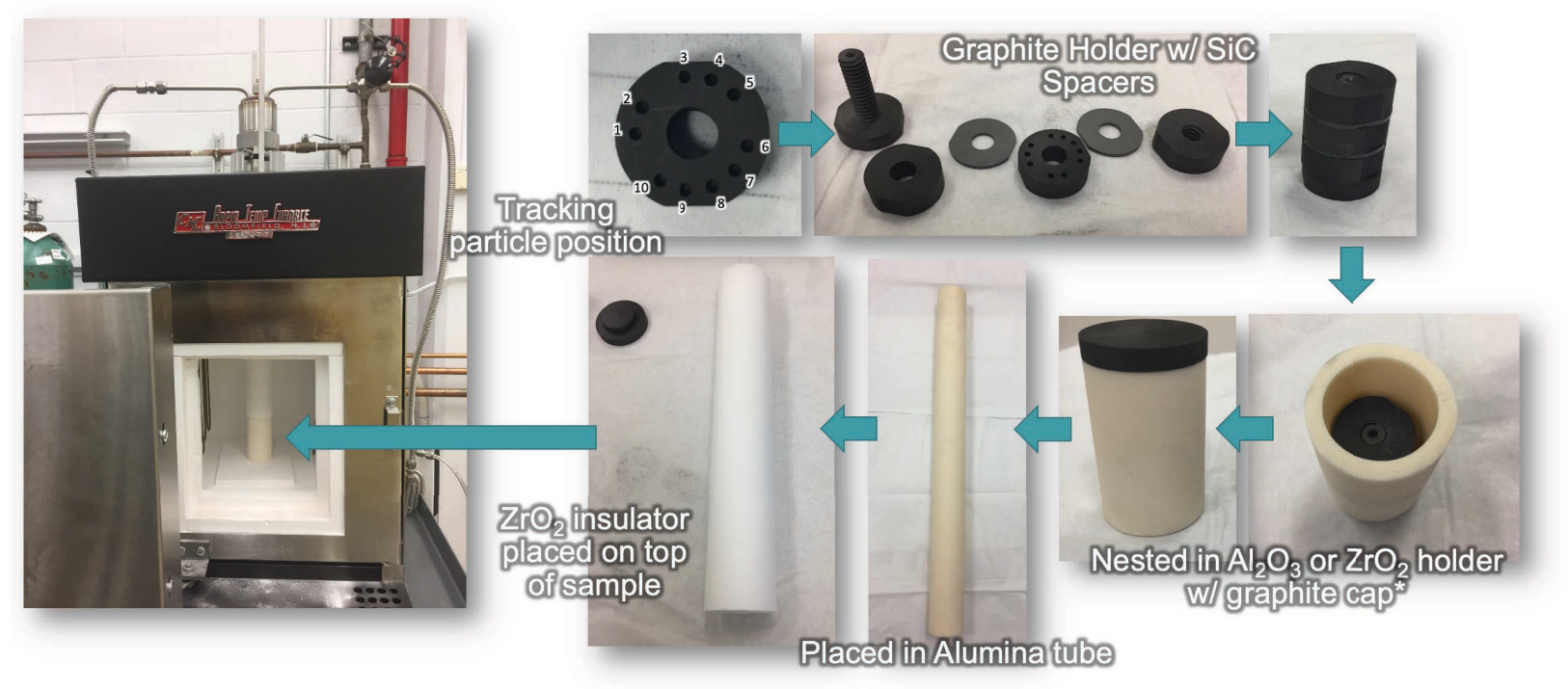

Figure 5. Display of furnace internals

The furnace is operated according to the internal standard operating procedure, "Standard Operating Procedure for Individual TRISO Particle Heating Tests," NFM-PIE-SOG-01. This document describes radiological controls, loading and unloading, and furnace operation. A total of 30 irradiated particles are permitted in the hood containing the two FITT systems based on radiological controls for the building. This constraint limits the total number of particles that can be examined for a given test.

Prior to operation, the furnace system is checked for gas tightness by executing three pump and purge cycles. The vacuum is checked by isolating the ceramic tube from the exhaust and roughing pump and monitoring the system pressure. If no increase in pressure is detected after a hold of $\sim 5 \mathrm{~min}$, then the integrity of the system is deemed appropriate to conduct a thermal exposure. The experiments are run under flowing ultra high purity argon (UHP Ar) at an overpressure of $\sim 5-8$ psi to limit possible ingress of external air in the event of small leaks forming. The flow rate is set to $\sim 2.5-6.3 \mathrm{ml} / \mathrm{min}$. The temperature is monitored and controlled using Type B thermocouples. The accuracy of the thermocouple readout relative to the sample position was checked by cycling the furnace temperature with an external Type B thermocouple positioned in the location of the sample volume. Both thermocouples were within $5^{\circ} \mathrm{C}$ at all times. This represents the magnitude of the uncertainty in the furnace operational temperature. The relative stability of the temperature is recorded during each run by recording the thermocouple output on a data logger. The furnace is run with an overtemperature alarm $50^{\circ} \mathrm{C}$ higher than the maximum operating temperature.

Initial tests identified some operational and design issues that were addressed in subsequent runs. This included requirements to bake out the primary furnace tube and furnace internal components prior to use, as presumed contamination from the ceramic binder material was observed interacting with the sample holder, and in some cases it interacted with the particles. Similar behavior was observed in SiC oxidation experiments in which binder constituents may have led to accelerated oxidation behavior (Opila, 1995). The standard implemented bake-out conditions were generally $1,630^{\circ} \mathrm{C}$ for $200 \mathrm{~h}$. For higher temperature runs $\left(1,600^{\circ} \mathrm{C}\right)$ the alumina furnace internals were replaced with zirconia due to the lower partial pressures of volatile species evolved from the base material. 


\section{EXPERIMENTAL TESTING APPROACH}

Long-term thermal exposure testing focused on AGR-2 Compact 5-4-2 particles. These particles represent irradiation conditions that were average relative to the range in irradiated conditions explored by AGR-1 and AGR-2. The as-irradiated AGR-2 Compact 5-4-2 average fast fluence was $3.14 \times 10^{25} \mathrm{n} / \mathrm{m}^{2}(\mathrm{E}>0.18$ $\mathrm{MeV}$ ), the burnup was $12.03 \%$ fission per initial metal atom, and the compact time-average, volumeaverage temperature was $1,071^{\circ} \mathrm{C}$ (Hawkes 2014, Sterbentz 2014). Prior to thermal exposure, the individual particles were subjected to deconsolidation leach-burn-leach (Hunn et al. 2018b) to determine the concentration of fission products outside the SiC layer and to identify possible failed particles. After the deconsolidation, the particles were liberated from the compact, and after the burn stage, the residual matrix and OPyC layers were removed. At this stage, the particles were considered burnback, as the SiC layer was now the outer particle layer. The entire process resulted in the particles experiencing four $24 \mathrm{~h}$ exposures to boiling nitric acid and a $24 \mathrm{~h}$ burn step in air at $750^{\circ} \mathrm{C}$.

The long-term thermal exposure test matrix was developed to confirm the bimodal release behavior of ${ }^{110 \mathrm{~m}} \mathrm{Ag}$ observed during stepwise and transient safety tests, and to support potential observation of active through-layer release of ${ }^{154} \mathrm{Eu}$ and other radionuclides with convenient gamma signatures (e.g., ${ }^{106} \mathrm{Ru}$, ${ }^{125} \mathrm{Sb},{ }^{134} \mathrm{Cs},{ }^{137} \mathrm{Cs}$, and ${ }^{144} \mathrm{Ce}$ ). Table 2 shows the test matrix for the long-term testing experiment. The temperatures and times span the conditions expected for the lower temperature rapid release relative to behavior observed at standard safety testing conditions of $1,600^{\circ} \mathrm{C}$ for $300 \mathrm{~h}$, with no suggestion of additional release observed. The expectation was to confirm the rapid release of ${ }^{110 \mathrm{~m}} \mathrm{Ag}$ at low temperature conditions $\left(1,150-1,300^{\circ} \mathrm{C}\right)$ relative to $1,600^{\circ} \mathrm{C}$ by comparing identical exposure times.

Table 2. Long-term thermal exposure test matrix.

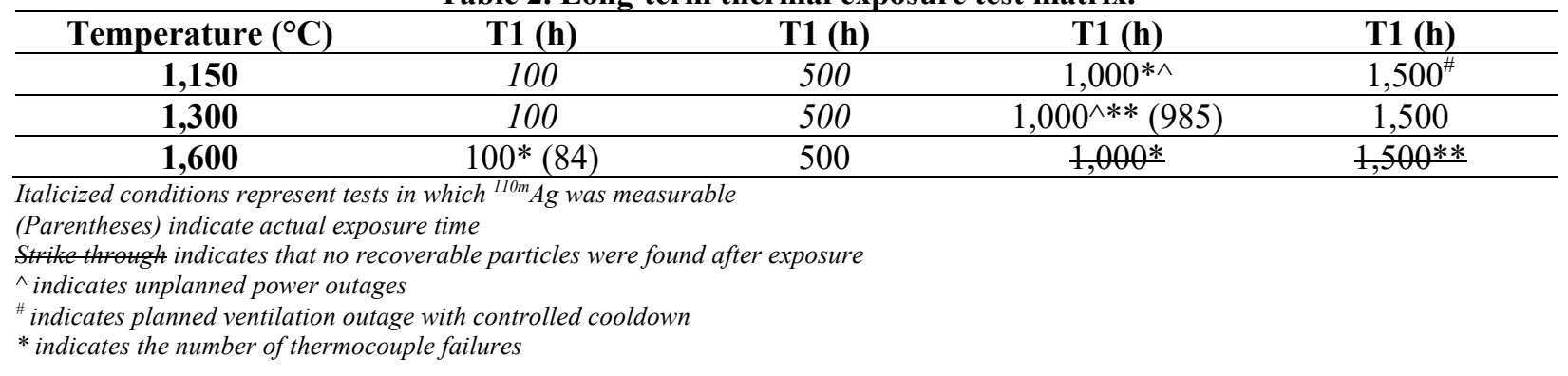

The first thermal schedule included ramp and cool rates set at $10^{\circ} \mathrm{C} / \mathrm{min}$ to avoid dwelling in the temperature regimes associated with rapid release while reaching the target temperature. This ramping and cooling rate was estimated to be acceptable and was not expected to lead to particle failure based on the ramping and cooling rates experienced in whole-compact safety tests. This includes observations from tests in which intentional rapid cooldown thermal cycles resulted in no particle failures (Hunn et al. 2015a). The initial runs of $1,150-1,300^{\circ} \mathrm{C}$ for $100-1,000 \mathrm{~h}$ and $1,600^{\circ} \mathrm{C}$ for $100 \mathrm{~h}$ used $10^{\circ} \mathrm{C} / \mathrm{min}$ ramp and cool rates. The 1,150 and $1,300^{\circ} \mathrm{C}, 1,000 \mathrm{~h}$ tests and the $1,600^{\circ} \mathrm{C} 100 \mathrm{~h}$ test shared common thermocouple failures with the manufacturer-supplied Type $\mathrm{B}$ thermocouples (manufacturer rated to $1,700^{\circ} \mathrm{C}$ ). These thermocouples had an unprotected bead where the failure was occuring.

Subsequent tests at $1,150-1,300^{\circ} \mathrm{C}$ for $1,500 \mathrm{~h}$ and $1,600^{\circ} \mathrm{C}$ for $500-1,500 \mathrm{~h}$ used Omega ${ }^{\circledR}$ Type B thermocouples with a ceramic protection covering the bead. This change resulted in improved thermocouple lifetimes; however, thermocouple failure was not eliminated. Failures previously observed at the thermocouple bead were now occurring at the location where the thermocouple entered the furnace interior due to slight creep in the alumina protective sheath. Because particle failure was also observed in $1,150-1,300^{\circ} \mathrm{C}$ for $100-500 \mathrm{~h}$ runs without thermocouple failures, the particle handling approach was 
modified to limit handling, and a new thermal schedule was implemented using a $5^{\circ} \mathrm{C} / \mathrm{min}$ ramp rate to $250^{\circ} \mathrm{C}$, with a $2 \mathrm{~h}$ hold followed by a $5^{\circ} \mathrm{C} / \mathrm{min}$ ramp up to the target temperature. The slower ramp rates were implemented to mitigate possible particle failures, and revised particle handling approaches were also implemented. The hold at $250^{\circ} \mathrm{C}$ was implemented to drive out any moisture from the system before reaching temperature. These changes led to improved particle failure rates and successful tests. The $1,600^{\circ} \mathrm{C}, 1,000-1,500 \mathrm{~h}$ tests experienced oxygen ingress due to the likely thermal shock and cracking of the primary alumina furnace tube. This led to oxidation and failure of all particles.

Each test leveraged a new set of 10 burnback particles, with pre- and post-test inventories measured by IMGA analysis. The inventory was measured using a standard IMGA live count of 4-6 h, as outlined in the literature (Hunn et al. 2013). The activity is reported in becquerel per particle (Bq/particles) and is decay-corrected to end-of-life plus one day. Typical IMGA analysis serves to demonstrate the general fission product activity among a population of irradiated or safety tested particles. As such the population statistics are reported and the activity is normalized to provide context to the overall release behavior. In particular the measured vs. calculated $(\mathrm{M} / \mathrm{C})$ inventory fraction is reported to provide context to the end of the irradiation particle inventory. The $\mathrm{M} / \mathrm{C}$ assessment is also a convenient way to account for particleto-particle variations like kernel size, which may account for differences in activity not related to release behavior. This normalization is performed by using well-retained isotopes such as ${ }^{137} \mathrm{Cs}$ to account for particle-to-particle variability in initial fissile content and burnup (Hunn et al. 2013). Other typical inventory measurements which provide unique insight into individual particle retention behavior are measured vs. average (M/A) or measured vs. adjusted average (M/AA). Hunn et al. (2020) describe these different particle inventory analysis approaches in detail.

Neither M/C nor M/AA are used in this work as they are influenced by the activity of multiple isotopes (i.e. normalized to well-retained isotopes) to account for variations in kernel size, etc. These adjustments are not needed for the analysis in this work, which is unique, as the activity of the same particles is measured before and after exposure to temperature to explore release. As such, direct comparison of the decay-correct activity pre-test $\left(A_{i}\right.$ Pre-test $)$ and post-test $\left(A_{i}\right.$ Post-test $)$ can be used to determine the extent of release observed, in which $A_{i}$ is the measured activity in particle $i$ for the specific isotopes in question. The activity for each relevant radioisotope explored in this work is presented along with measurement of the percentage change in activity (pre-test versus post-test), Eq. (3).

$$
\% \text { change }=\frac{\left(A_{i} \text { Post }- \text { test }-A_{i} \text { Pre-test }\right)}{A_{i} \text { Pretest }} / 100
$$

In addition to reporting pre-test and post-test activity for each particle, the silver inventory is also reported in terms of the pre-test and post-test silver activity divided by the mean calculated ${ }^{110 \mathrm{~m}} \mathrm{Ag}$ activity; $\overline{A_{\text {calc }}\left({ }^{110 m} \mathrm{Ag}\right)}$. This ratio is denoted as $\mathrm{A} / \mathrm{C}$ and provides general context for the extent of silver released prior to the out-of-pile testing however, corrections for kernel size and other variables are not included, which are generally included in M/C. Determination of the mean calculated ${ }^{110 \mathrm{~m}} \mathrm{Ag}$ activity; $\overline{A_{\text {calc }}\left({ }^{110 m} \mathrm{Ag}\right)}$ is shown in Eq. (4). The term $N_{\text {calc }}\left({ }^{110 m} \mathrm{Ag}\right.$ ) is the total number of ${ }^{110 \mathrm{~m}} \mathrm{Ag}$ atoms in the compact generated by fission, in which $N_{\text {calc }}\left({ }^{110 m} \mathrm{Ag}\right)$ was determined by Sterbentz for each compact in AGR-2 at end-of-life plus one day, assuming complete retention during the course of the irradiation (Sterbentz 2014). The total number of atoms per compact was converted to a mean particle activity by dividing by the mean measured number of particles in an AGR-2 UCO compact (3176) and multiplying by the ${ }^{110 \mathrm{~m}} \mathrm{Ag}$ decay constant, $\lambda\left({ }^{110 \mathrm{~m}} \mathrm{Ag}\right)$ (Hunn et al. 2013). The magnitude of $\overline{A_{\text {calc }}\left({ }^{10 m} \mathrm{Ag}\right)}$ for AGR-2 Compact 5-4-2 was $5.53 \times 10^{4} \mathrm{~Bq} /$ particle.

$$
\overline{A_{\text {calc }}\left({ }^{110 \mathrm{~m}} A g\right)}=\lambda\left({ }^{110 \mathrm{~m}} \mathrm{Ag}\right) \cdot\left[N_{\text {calc }}\left({ }^{110 \mathrm{~m}} \mathrm{Ag}\right) / 3176\right]
$$


Measuring the activity, $A_{i}$, pre- and post-test provides a direct observation of the release behavior for the individual particle. Uncertainty does exist in the measurement. One source of this uncertainty is the use of a calculated value to determine $\mathrm{A} / \mathrm{C}$; however, this is consistent across the pre- and post-test measurements, and it only impacts the relative magnitude of the average $\mathrm{A} / \mathrm{C}$ for all particles measured within a compact, so if the $A_{\text {calc }}$ is not accurate, then the general magnitude of $\mathrm{A} / \mathrm{C}$ for complete retention will deviate from unity. However, uncertainty exists in the gamma analysis based on the peak statistics (counts above background and continuum noise). For strong gamma signals such as ${ }^{154} \mathrm{Eu}$, the relative uncertainty is low $(<0.5 \%)$. However, for lower activity fission products such as ${ }^{110 \mathrm{~m}} \mathrm{Ag}$, the $A_{i}$ uncertainty must be taken under consideration. For other gamma signals non-negligible uncertainty may be present due to decay of the fission products inventory. For example, radioisotopes such as ${ }^{106} \mathrm{Ru}$ and ${ }^{144} \mathrm{Ce}$ had undergone $\sim 4.2$ and $\sim 5.5$ half-lives each prior to the start of this work. 


\section{RESULTS}

\subsection{RETAINED INVENTORY ANALYSIS}

The measured pre-test and post-test activities for ${ }^{106} \mathrm{Ru},{ }^{125} \mathrm{Sb},{ }^{134} \mathrm{Cs},{ }^{137} \mathrm{Cs},{ }^{144} \mathrm{Ce}$, and ${ }^{154} \mathrm{Eu}$ for the $1,150^{\circ} \mathrm{C}$ test condition are reported in Table 3 through Table 6 . No obvious indication of uniform additional release of ${ }^{106} \mathrm{Ru},{ }^{125} \mathrm{Sb},{ }^{134} \mathrm{Cs},{ }^{137} \mathrm{Cs},{ }^{144} \mathrm{Ce}$, and ${ }^{154} \mathrm{Eu}$ was determined from the activity variation assessment. This is based on the observations that the mean percentage change (pre- and post-test activity comparison) was generally $0-3 \%$, which is within the expected uncertainty. Some exceptions were observed. First, ${ }^{154}$ Eu variation for the $1,150{ }^{\circ} \mathrm{C}, 1,000 \mathrm{~h}$ exposure showed two particles with more than a or equal to $-5 \%$ percentage change: particles 542-P03 (-23\%) and 542-P17 (-5\%). Here negative (-) percentage change indicate release or lower measured activity after thermal exposure. These values represent the largest activity variation at $1,150^{\circ} \mathrm{C}$ conditions. The $-5 \%$ change in ${ }^{154} \mathrm{Eu}$ activity for 542-P17 is likely within the uncertainty, as a maximum percentage change of $+6 \%$ was observed for comparative pre-test/post-test analysis. In general, the uncertainty associated with the measurement is approximated to be on the order of the maximum positive percentage change in measured activity from the pre-test/post-test comparison. However, a -23\% variation in activity post-test for $542-\mathrm{P} 03$ is well outside the measurement uncertainty and represents an outlier relative to the other particles in the test condition; this indicates particle-dependent release of ${ }^{154} \mathrm{Eu}$. During transfer to the IMGA cell for post-test IMGA analysis of the $1,150^{\circ} \mathrm{C}, 1,000 \mathrm{~h}$ exposure, the particle identities were lost, which reduced confidence in the direct comparisons (Table 5). To estimate the particle identities' post-test for the $1,150{ }^{\circ} \mathrm{C}, 1,000 \mathrm{~h}$ exposure, the variation in measured activity $\left({ }^{106} \mathrm{Ru},{ }^{125} \mathrm{Sb},{ }^{134} \mathrm{Cs},{ }^{137} \mathrm{Cs},{ }^{144} \mathrm{Ce}\right.$, and $\left.{ }^{154} \mathrm{Eu}\right)$ was compared to the pre-test activities of all particles. The particles which represented the best fit in preand post-test activities were paired for the analysis. The inventory was compared for each unknown particle identified; particles were excluded from consideration if the difference in activities were $\pm 10 \%$ for the well-retained fission products, which is on the order of the maximum deviation in percentage difference in ${ }^{106} \mathrm{Ru}$ and ${ }^{125} \mathrm{Sb}$ and greater than the maximum percentage change for ${ }^{134} \mathrm{Cs}$, ${ }^{137} \mathrm{Cs}$, and ${ }^{144} \mathrm{Ce}$ observed for all other exposures. The $-23 \%$ change in ${ }^{154} \mathrm{Eu}$ activity post-test for 542-P03 is clearly an outlier; however, the other measured isotopes showed pre- and post-test deviations of $-2-7 \%$, which were typical of all other exposures. Comparing the percentage difference between the post-test ${ }^{154} \mathrm{Eu}$ activity for the low ${ }^{154} \mathrm{Eu}$ particle with all other pre-test particle ${ }^{154} \mathrm{Eu}$ activities resulted in a range of $-26 \%$ to $-20 \%$, which confirms that this particle released ${ }^{154} \mathrm{Eu}$, even if the presumed identity of $542-\mathrm{P} 03$ is incorrect. This particle is also not likely a failed particle, as the particle represented the highest relative cesium activity compared to all other measured particles. Particle 542-P146 showed a $-4 \%$ change in ${ }^{125} \mathrm{Sb}$ activity post-test which was the most negative percentage change for ${ }^{125} \mathrm{Sb}$ post-test. The negative percentage change in activity, does not indicate release, as it is within the uncertainty of the analysis, given that a maximum positive deviation of $+8 \%$ was measured for ${ }^{125} \mathrm{Sb}$ in the $1,150^{\circ} \mathrm{C}$ exposures while a maximum positive percentage change of $+12 \%$ was observed overall all exposures $\left(\right.$ see $1,300^{\circ} \mathrm{C}$ analysis). Again, the maximum positive increase in activity likely reflects the uncertainty in the analysis, and any negative deviation (implying release) within the range $( \pm$ ) defined by the maximum cannot confidently be considered to indicate the particle released any inventory.

Overall, the number of particles with negative percentage change in ${ }^{154} \mathrm{Eu}$ activity from intact particles at $1,150^{\circ} \mathrm{C}$ increases after the initial $100 \mathrm{~h}$ exposure up to the $1,000 \mathrm{~h}$ exposure. Here $30 \%, 57 \%$, and $75 \%$ of the particles show negative percentage change in ${ }^{154} \mathrm{Eu}$ activity at $100 \mathrm{~h}, 500 \mathrm{~h}$ and 1,000 h respectively. This would suggest a time-dependent release behavior, however, only $20 \%$ of the intact particles show negative percentage change in ${ }^{154} \mathrm{Eu}$ inventory at the $1,150^{\circ} \mathrm{C}, 1,500 \mathrm{~h}$ exposure supporting the conclusion that no uniform ${ }^{154} \mathrm{Eu}$ release is observed at $1,150^{\circ} \mathrm{C}$ over the exposure times explored. 
Table 3. Pre- and post-test $\mathrm{A} / \mathrm{C}$ analysis for $1,150^{\circ} \mathrm{C}, 100 \mathrm{~h}$ FITT run

\begin{tabular}{|c|c|c|c|c|c|c|c|c|c|c|c|c|c|c|c|c|c|c|}
\hline \multicolumn{19}{|c|}{ Pre-test $A_{i}(B q /$ particle) | Post-test (Bq/particle) $\mid \%$ Change in $A$} \\
\hline \multirow{2}{*}{$\begin{array}{l}\text { Particle } \\
542-\mathrm{P} 06 \\
\end{array}$} & \multicolumn{3}{|c|}{${ }^{106} \mathrm{Ru} A_{i}\left(\times 10^{7}\right)$} & \multicolumn{3}{|c|}{${ }^{125} \mathrm{Sb} A_{i}\left(\times 10^{5}\right)$} & \multicolumn{3}{|c|}{${ }^{134} \mathrm{Cs} A_{i}\left(\times 10^{6}\right)$} & \multicolumn{3}{|c|}{${ }^{137} \mathrm{Cs} A_{i}\left(\times 10^{6}\right)$} & \multicolumn{3}{|c|}{${ }^{144} \mathrm{Ce} A_{i}\left(\times 10^{7}\right)$} & \multicolumn{3}{|c|}{${ }^{154} \mathrm{Eu} A_{i}\left(\times 10^{5}\right)$} \\
\hline & 1.53 & 1.53 & $1 \%$ & 2.65 & 2.76 & $4 \%$ & 5.71 & 5.74 & $0 \%$ & 5.60 & 5.70 & $2 \%$ & 5.09 & 5.22 & $3 \%$ & 1.86 & 1.91 & $2 \%$ \\
\hline 542-P07 & 1.47 & 1.46 & $0 \%$ & 2.52 & 2.52 & $0 \%$ & 5.52 & 5.57 & $1 \%$ & 5.21 & 5.29 & $2 \%$ & 4.35 & 4.44 & $2 \%$ & 1.87 & 1.82 & $-3 \%$ \\
\hline 542-P08 & 1.58 & 1.60 & $1 \%$ & 2.66 & 2.72 & $2 \%$ & 5.84 & 5.88 & $1 \%$ & 5.51 & 5.64 & $2 \%$ & 4.58 & 4.64 & $1 \%$ & 1.94 & 1.89 & $-3 \%$ \\
\hline 542-P14 & 1.45 & 1.48 & $2 \%$ & 2.48 & 2.54 & $2 \%$ & 4.95 & 5.05 & $2 \%$ & 4.95 & 5.09 & $3 \%$ & 4.41 & 4.52 & $3 \%$ & 1.60 & 1.70 & $6 \%$ \\
\hline 542-P18 & 1.66 & 1.68 & $1 \%$ & 2.75 & 2.83 & $3 \%$ & 5.98 & 6.02 & $1 \%$ & 5.59 & 5.71 & $2 \%$ & 4.85 & 4.97 & $2 \%$ & 1.95 & 1.98 & $2 \%$ \\
\hline 542-P19 & 1.52 & 1.53 & $1 \%$ & 2.57 & 2.61 & $1 \%$ & 4.87 & 4.90 & $0 \%$ & 5.11 & 5.19 & $2 \%$ & 5.48 & 5.48 & $0 \%$ & 1.57 & 1.54 & $-2 \%$ \\
\hline 542-P21 & 1.41 & 1.42 & $0 \%$ & 2.47 & 2.50 & $1 \%$ & 5.10 & 5.11 & $0 \%$ & 5.05 & 5.12 & $1 \%$ & 4.49 & 4.48 & $0 \%$ & 1.69 & 1.69 & $0 \%$ \\
\hline 542-P23 & 1.80 & 1.81 & $1 \%$ & 2.86 & 3.01 & $5 \%$ & 6.50 & 6.60 & $1 \%$ & 5.87 & 6.00 & $2 \%$ & 4.63 & 4.78 & $3 \%$ & 2.11 & 2.20 & $4 \%$ \\
\hline 542-P28 & 1.73 & 1.76 & $1 \%$ & 2.87 & 3.02 & $5 \%$ & 6.40 & 6.11 & $-5 \%$ & 5.90 & 6.02 & $2 \%$ & 4.66 & 4.71 & $1 \%$ & 2.04 & 2.17 & $6 \%$ \\
\hline 542-P30 & 1.68 & 1.69 & $1 \%$ & 2.85 & 2.99 & $5 \%$ & 5.48 & 5.51 & $1 \%$ & 5.68 & 5.77 & $2 \%$ & 5.52 & 5.57 & $1 \%$ & 1.80 & 1.81 & $0 \%$ \\
\hline Maximum & 1.80 & 1.81 & $2 \%$ & 2.87 & 3.02 & $5 \%$ & 6.50 & 6.60 & $2 \%$ & 5.90 & 6.02 & $3 \%$ & 5.52 & 5.57 & $3 \%$ & 2.11 & 2.20 & $6 \%$ \\
\hline Minimum & 1.41 & 1.42 & $0 \%$ & 2.47 & 2.50 & $0 \%$ & 4.87 & 4.90 & $-5 \%$ & 4.95 & 5.09 & $1 \%$ & 4.35 & 4.44 & $0 \%$ & 1.57 & 1.54 & $-3 \%$ \\
\hline Mean & 1.58 & 1.60 & $1 \%$ & 2.67 & 2.75 & $3 \%$ & 5.64 & 5.65 & $0 \%$ & 5.45 & 5.55 & $2 \%$ & 4.80 & 4.88 & $2 \%$ & 1.84 & 1.87 & $1 \%$ \\
\hline$S t d D e v$ & 0.13 & 0.13 & $1 \%$ & 0.16 & 2.09 & $2 \%$ & 0.56 & 5.32 & $2 \%$ & 0.34 & 0.35 & $0 \%$ & 0.42 & 0.41 & $1 \%$ & 0.18 & 0.21 & $3 \%$ \\
\hline
\end{tabular}

Table 4. Pre- and post-test $\mathrm{A} / \mathrm{C}$ analysis for $1,150^{\circ} \mathrm{C}, 500 \mathrm{~h}$ FITT run

\begin{tabular}{|c|c|c|c|c|c|c|c|c|c|c|c|c|c|c|c|c|c|c|}
\hline \multirow{3}{*}{$\begin{array}{l}\text { Particle } \\
542 \mathrm{P} 02\end{array}$} & \multicolumn{18}{|c|}{ Pre-test $\mathbf{A}_{\mathbf{i}}\left(\mathrm{Bq} /\right.$ particle) $\mid$ Post-test (Bq/particle) | \% Change in $\mathrm{A}^{*}$} \\
\hline & \multicolumn{3}{|c|}{${ }^{106} \mathrm{Ru} A_{i}\left(\times 10^{7}\right)$} & \multicolumn{3}{|c|}{${ }^{125} \mathrm{Sb} A_{i}\left(\times 10^{5}\right)$} & \multicolumn{3}{|c|}{${ }^{134} \mathrm{Cs} A_{i}\left(\times 10^{6}\right)$} & \multicolumn{3}{|c|}{${ }^{137} \mathrm{Cs} A_{i}\left(\times 10^{6}\right)$} & \multicolumn{3}{|c|}{${ }^{144} \mathrm{Ce} A_{i}\left(\times 10^{7}\right)$} & \multicolumn{3}{|c|}{${ }^{154} \mathrm{Eu} A_{i}\left(\times 10^{5}\right)$} \\
\hline & 1.52 & NA & $\mathrm{NA}$ & 2.47 & NA & $\mathrm{NA}$ & 5.13 & NA & $\mathrm{NA}$ & 4.91 & $\mathrm{NA}$ & NA & 4.33 & NA & NA & 1.72 & $\mathrm{NA}$ & $\mathrm{NA}$ \\
\hline 542-P29 & 1.58 & 1.60 & $1 \%$ & 2.60 & 2.70 & $4 \%$ & 5.27 & 5.58 & $6 \%$ & 5.33 & 5.47 & $3 \%$ & 4.59 & 4.73 & $3 \%$ & 1.86 & 1.89 & $2 \%$ \\
\hline 542-P31 & 1.64 & 1.65 & $1 \%$ & 2.79 & 2.90 & $4 \%$ & 5.15 & 5.03 & $-2 \%$ & 5.51 & 5.54 & $1 \%$ & 5.60 & 5.78 & $3 \%$ & 1.61 & 1.69 & $5 \%$ \\
\hline 542-P34 & 1.70 & 1.72 & $1 \%$ & 2.87 & 2.85 & $-1 \%$ & 5.73 & 5.78 & $1 \%$ & 5.73 & 5.83 & $2 \%$ & 5.32 & 5.45 & $2 \%$ & 1.90 & 1.91 & $1 \%$ \\
\hline $542-P 35$ & 1.49 & NA & NA & 2.50 & 0.00 & $\theta \%$ & 5.56 & NA & NA & 5.33 & NA & NA & 4.50 & NA & NA & 1.84 & NA & $\mathrm{NA}$ \\
\hline 542-P39 & 1.64 & 1.65 & $1 \%$ & 2.74 & 2.82 & $3 \%$ & 5.87 & 6.22 & $6 \%$ & 5.68 & 5.74 & $1 \%$ & 4.46 & 4.54 & $2 \%$ & 2.08 & 2.02 & $-3 \%$ \\
\hline 542-P43 & 1.54 & 1.55 & $1 \%$ & 2.75 & 2.75 & $0 \%$ & 5.39 & 5.40 & $0 \%$ & 5.45 & 5.52 & $1 \%$ & 5.30 & 5.36 & $1 \%$ & 1.76 & 1.73 & $-2 \%$ \\
\hline 542-P44 & 1.65 & 1.64 & $-1 \%$ & 2.82 & 2.93 & $4 \%$ & 6.03 & 6.01 & $0 \%$ & 6.01 & 5.98 & $0 \%$ & 5.18 & 5.22 & $1 \%$ & 1.98 & 1.91 & $-4 \%$ \\
\hline 542 P47 & 1.62 & NA & NA & 2.81 & NA & NA & 6.14 & NA & $\mathrm{NA}$ & 5.83 & NA & NA & 4.79 & NA & $\mathrm{NA}$ & 2.05 & NA & $\mathrm{NA}$ \\
\hline 542-P48 & 1.29 & 1.30 & $1 \%$ & 2.20 & 2.32 & $6 \%$ & 4.74 & 4.71 & $-1 \%$ & 4.67 & 4.79 & $3 \%$ & 4.27 & 4.43 & $4 \%$ & 1.54 & 1.52 & $-2 \%$ \\
\hline Maximum & 1.70 & 1.72 & $1 \%$ & 2.87 & 2.93 & $6 \%$ & 6.14 & 6.22 & $6 \%$ & 6.01 & 5.98 & $3 \%$ & 5.60 & 5.78 & $4 \%$ & 2.08 & 2.02 & $5 \%$ \\
\hline Minimum & 1.29 & 1.30 & $-1 \%$ & 2.20 & 2.32 & $-1 \%$ & 4.74 & 4.71 & $-2 \%$ & 4.67 & 4.79 & $0 \%$ & 4.27 & 4.43 & $1 \%$ & 1.54 & 1.52 & $-4 \%$ \\
\hline Mean & 1.57 & 1.59 & $1 \%$ & 2.65 & 2.75 & $3 \%$ & 5.50 & 5.53 & $1 \%$ & 5.44 & 5.55 & $1 \%$ & 4.83 & 5.07 & $2 \%$ & 1.83 & 1.81 & $0 \%$ \\
\hline Std Dev & 0.12 & 0.14 & $1 \%$ & 0.21 & 0.21 & $2 \%$ & 0.45 & 0.53 & $3 \%$ & 0.41 & 0.38 & $1 \%$ & 0.48 & 0.51 & $1 \%$ & 0.18 & 0.17 & $3 \%$ \\
\hline
\end{tabular}


Table 5. Pre- and post-test $\mathrm{A} / \mathrm{C}$ analysis for $1,150^{\circ} \mathrm{C}, 1,000 \mathrm{~h}$ FITT run

Pre-test $A_{i}(B q / p a r t i c l e) \mid$ Post-test (Bq/particle) | \% Change in $A^{*}$

\begin{tabular}{|c|c|c|c|c|c|c|c|c|c|c|c|c|c|c|c|c|c|c|}
\hline \multirow{2}{*}{$\begin{array}{l}\text { Particle } \\
542-\mathrm{P} 01\end{array}$} & \multicolumn{3}{|c|}{${ }^{106} \mathrm{Ru} A_{i}\left(\times 10^{7}\right)$} & \multicolumn{3}{|c|}{${ }^{125} \mathrm{Sb} A_{i}\left(\times 10^{5}\right)$} & \multicolumn{3}{|c|}{${ }^{134} \mathrm{Cs} A_{i}\left(\times 10^{6}\right)$} & \multicolumn{3}{|c|}{${ }^{137} \mathrm{Cs} A_{i}\left(\times 10^{6}\right)$} & \multicolumn{3}{|c|}{${ }^{144} \mathrm{Ce} A_{i}\left(\times 10^{7}\right)$} & \multicolumn{3}{|c|}{${ }^{154} \mathbf{E u} A_{i}\left(\times 10^{5}\right)$} \\
\hline & 1.57 & 1.62 & $3 \%$ & 2.64 & 2.75 & $4 \%$ & 5.63 & 5.80 & $3 \%$ & 5.50 & 5.65 & $3 \%$ & 5.05 & 5.25 & $4 \%$ & 1.83 & 1.83 & $0 \%$ \\
\hline${ }^{542-\mathrm{P}^{\wedge}{ }^{\wedge}}$ & 1.73 & 1.69 & $-2 \%$ & 2.79 & 2.97 & $6 \%$ & 6.17 & 6.22 & $1 \%$ & 5.99 & 6.10 & $2 \%$ & 5.43 & 5.79 & $7 \%$ & 1.96 & 1.51 & $-23 \%$ \\
\hline $542-\mathrm{P} 10$ & 1.64 & 1.63 & $-1 \%$ & 2.68 & 2.88 & $7 \%$ & 5.54 & 5.66 & $2 \%$ & 5.50 & 5.61 & $2 \%$ & 5.12 & 5.31 & $4 \%$ & 1.81 & 1.85 & $2 \%$ \\
\hline $542-\mathrm{P} 11$ & 1.48 & 1.45 & $-2 \%$ & 2.34 & 2.34 & $0 \%$ & 4.23 & 4.34 & $3 \%$ & 4.58 & 4.64 & $1 \%$ & 5.17 & 5.45 & $5 \%$ & 1.42 & 1.39 & $-2 \%$ \\
\hline 542-P16 & 1.62 & 1.68 & $4 \%$ & 2.75 & 2.96 & $8 \%$ & 5.36 & 5.49 & $2 \%$ & 5.51 & 5.61 & $2 \%$ & 5.24 & 5.39 & $3 \%$ & 1.81 & 1.80 & $-1 \%$ \\
\hline 542-P17 & 1.59 & 1.62 & $2 \%$ & 2.54 & 2.57 & $1 \%$ & 4.45 & 4.73 & $6 \%$ & 5.03 & 5.12 & $2 \%$ & 5.30 & 5.42 & $2 \%$ & 1.62 & 1.54 & $-5 \%$ \\
\hline $542-\mathrm{P} 20$ & 1.46 & 0.00 & $0 \%$ & 2.51 & 0.00 & $\theta \%$ & 5.29 & 0.00 & $\theta \%$ & 5.29 & 0.00 & $0 \%$ & 5.10 & 0.00 & $\theta \%$ & 1.73 & 0.00 & $0 \%$ \\
\hline 542-P25 & 1.61 & 1.61 & $-1 \%$ & 2.70 & 2.71 & $1 \%$ & 5.71 & 5.66 & $-1 \%$ & 5.53 & 5.52 & $0 \%$ & 5.01 & 5.07 & $1 \%$ & 1.85 & 1.82 & $-2 \%$ \\
\hline $542-\mathrm{P} 32$ & 1.43 & 0.00 & $0 \%$ & 2.47 & 0.00 & $\theta \%$ & 4.64 & 0.00 & $0 \%$ & 4.92 & 0.00 & $\theta \%$ & 4.84 & 0.00 & $\theta \%$ & 1.52 & 0.00 & $0 \%$ \\
\hline 542-P33 & 1.41 & 1.37 & $-3 \%$ & 2.52 & 2.49 & $-1 \%$ & 5.14 & 5.13 & $0 \%$ & 5.05 & 5.01 & $-1 \%$ & 4.52 & 4.65 & $3 \%$ & 1.70 & 1.67 & $-2 \%$ \\
\hline Maximum & 1.73 & 1.69 & $4 \%$ & 2.79 & 2.97 & $8 \%$ & 6.17 & 6.22 & $6 \%$ & 5.99 & 6.10 & $3 \%$ & 5.43 & 5.79 & $7 \%$ & 1.96 & 1.85 & $2 \%$ \\
\hline Minimum & 1.41 & 1.37 & $-3 \%$ & 2.34 & 2.34 & $-1 \%$ & 4.23 & 4.34 & $-1 \%$ & 4.58 & 4.64 & $-1 \%$ & 4.52 & 4.65 & $1 \%$ & 1.42 & 1.39 & $-23 \%$ \\
\hline Mean & 1.55 & 1.58 & $0 \%$ & 2.59 & 2.71 & $3 \%$ & 5.22 & 5.38 & $2 \%$ & 5.29 & 5.41 & $1 \%$ & 5.08 & 5.29 & $4 \%$ & 1.73 & 1.68 & $-4 \%$ \\
\hline Std Dev & 0.11 & 0.11 & $2 \%$ & 0.14 & 0.23 & $4 \%$ & 0.61 & 0.61 & $2 \%$ & 0.40 & 0.46 & $1 \%$ & 0.26 & 0.33 & $2 \%$ & 0.17 & 0.18 & $8 \%$ \\
\hline
\end{tabular}

* The exact identity of each particle was lost during transfer into the IMGA hot cell; the post-test identity was estimated by correlating measured post-test activity with pre-test activity for all isotopes.

${ }^{\wedge}$ bold items represent particles of interest concerning change in activity pre-test versus post-test.

Table 6. Pre- and post-test $\mathrm{A} / \mathrm{C}$ analysis for $1,150^{\circ} \mathrm{C}, 1,500 \mathrm{~h}$ FITT run

\begin{tabular}{|c|c|c|c|c|c|c|c|c|c|c|c|c|c|c|c|c|c|c|}
\hline \multicolumn{19}{|c|}{ Pre-test $A_{i}(B q /$ particle) $\mid$ Post-test (Bq/particle) $\mid \%$ Change in $A$} \\
\hline \multirow{2}{*}{$\begin{array}{c}\text { Particle } \\
542-\mathrm{P} 141\end{array}$} & \multicolumn{3}{|c|}{${ }^{106} \mathrm{Ru} A_{i}\left(\times 10^{7}\right)$} & \multicolumn{3}{|c|}{${ }^{125} \mathrm{Sb} A_{i}\left(\times 10^{5}\right)$} & \multicolumn{3}{|c|}{${ }^{134} \mathrm{Cs} A_{i}\left(\times 10^{6}\right)$} & \multicolumn{3}{|c|}{${ }^{137} \mathrm{Cs} A_{i}\left(\times 10^{6}\right)$} & \multicolumn{3}{|c|}{${ }^{144} \mathrm{Ce} A_{i}\left(\times 10^{7}\right)$} & \multicolumn{3}{|c|}{${ }^{154} \mathrm{Eu} A_{i}\left(\times 10^{5}\right)$} \\
\hline & 1.64 & 1.69 & $3 \%$ & 2.80 & 3.03 & $8 \%$ & 5.71 & 5.88 & $3 \%$ & 5.67 & 5.81 & $2 \%$ & 5.28 & 5.55 & $5 \%$ & 1.89 & 1.90 & $0 \%$ \\
\hline 542-P142 & 1.54 & 1.66 & $8 \%$ & 2.77 & 2.75 & $-1 \%$ & 5.76 & 5.85 & $2 \%$ & 5.55 & 5.69 & $2 \%$ & 4.76 & 4.73 & $-1 \%$ & 1.88 & 1.90 & $1 \%$ \\
\hline 542-P143 & 1.51 & 1.52 & $1 \%$ & 2.54 & 2.72 & $7 \%$ & 5.75 & 5.86 & $2 \%$ & 5.19 & 5.31 & $2 \%$ & 4.32 & 4.28 & $-1 \%$ & 1.89 & 1.89 & $0 \%$ \\
\hline $542-\mathrm{P} 144$ & 1.43 & 1.42 & $-1 \%$ & 2.53 & 2.56 & $1 \%$ & 5.55 & 5.69 & $3 \%$ & 5.37 & 5.47 & $2 \%$ & 4.85 & 4.92 & $2 \%$ & 1.77 & 1.79 & $1 \%$ \\
\hline 542-P145 & 1.43 & 1.47 & $3 \%$ & 2.46 & 2.67 & $8 \%$ & 5.25 & 5.33 & $2 \%$ & 5.38 & 5.48 & $2 \%$ & 5.28 & 5.30 & $0 \%$ & 1.68 & 1.67 & $-1 \%$ \\
\hline 542-P146 & 1.78 & 1.76 & $-1 \%$ & 3.03 & 2.89 & $-4 \%$ & 6.29 & 6.40 & $2 \%$ & 5.86 & 6.02 & $3 \%$ & 5.03 & 5.08 & $1 \%$ & 2.06 & 2.09 & $2 \%$ \\
\hline 542-P147 & 1.67 & 1.69 & $1 \%$ & 2.85 & 3.05 & $7 \%$ & 5.53 & 5.57 & $1 \%$ & 5.59 & 5.71 & $2 \%$ & 5.33 & 5.46 & $3 \%$ & 1.77 & 1.82 & $3 \%$ \\
\hline 542-P148 & 1.52 & 1.56 & $2 \%$ & 2.63 & 2.70 & $3 \%$ & 4.96 & 5.01 & $1 \%$ & 5.10 & 5.21 & $2 \%$ & 5.31 & 5.35 & $1 \%$ & 1.58 & 1.60 & $1 \%$ \\
\hline 542-P149 & 1.51 & 1.48 & $-2 \%$ & 2.64 & 2.57 & $-3 \%$ & 5.24 & 5.35 & $2 \%$ & 5.21 & 5.33 & $2 \%$ & 5.07 & 4.81 & $-5 \%$ & 1.72 & 1.74 & $1 \%$ \\
\hline 542-P150 & 1.52 & 1.51 & $0 \%$ & 2.55 & 2.57 & $1 \%$ & 4.74 & 4.79 & $1 \%$ & 4.95 & 5.04 & $2 \%$ & 5.22 & 5.29 & $1 \%$ & 1.53 & 1.50 & $-2 \%$ \\
\hline Maximum & 1.78 & 1.76 & $8 \%$ & 3.03 & 3.05 & $8 \%$ & 6.29 & 6.40 & $3 \%$ & 5.86 & 6.02 & $3 \%$ & 5.33 & 5.55 & $5 \%$ & 2.06 & 2.09 & $3 \%$ \\
\hline Minimum & 1.43 & 1.42 & $-2 \%$ & 2.46 & 2.56 & $-4 \%$ & 4.74 & 4.79 & $1 \%$ & 4.95 & 5.04 & $2 \%$ & 4.32 & 4.28 & $-5 \%$ & 1.53 & 1.50 & $-2 \%$ \\
\hline Mean & 1.55 & 1.58 & $1 \%$ & 2.68 & 2.75 & $3 \%$ & 5.48 & 5.57 & $2 \%$ & 5.39 & 5.51 & $2 \%$ & 5.05 & 5.08 & $1 \%$ & 1.78 & 1.79 & $1 \%$ \\
\hline Std Dev & 0.11 & 0.11 & $3 \%$ & 0.18 & 0.18 & $5 \%$ & 0.45 & 0.47 & $1 \%$ & 0.28 & 0.30 & $0 \%$ & 0.32 & 0.39 & $3 \%$ & 0.16 & 0.17 & $1 \%$ \\
\hline
\end{tabular}


The measured activity for ${ }^{106} \mathrm{Ru},{ }^{125} \mathrm{Sb},{ }^{134} \mathrm{Cs},{ }^{137} \mathrm{Cs},{ }^{144} \mathrm{Ce}$, and ${ }^{154} \mathrm{Eu}$ for the $1,300{ }^{\circ} \mathrm{C}$ test conditions are reported in Table 7 through Table 10. No obvious indication of uniform additional release of ${ }^{106} \mathrm{Ru},{ }^{125} \mathrm{Sb}$, ${ }^{134} \mathrm{Cs},{ }^{137} \mathrm{Cs},{ }^{144} \mathrm{Ce}$, and ${ }^{154} \mathrm{Eu}$ was determined from the measured fractional changes. This is based on the observations that the mean percentage change (pre- and post-test comparison) was generally $-4-3 \%$, which is within the expected uncertainty based on the maximum percentage change observed for comparative pre-test/post-test analysis. Similar to the $1,150^{\circ} \mathrm{C}$ exposures no clear trend in increasing overall release behavior was observed for longer exposure times. For example, at $1,300^{\circ} \mathrm{C}, 100-985 \mathrm{~h}$, $70-90 \%$ of the intact particles showed negative percentage change in ${ }^{154} \mathrm{Eu}$ activity post-test.

Comparatively at $1,300^{\circ} \mathrm{C}, 1,500 \mathrm{~h}$ only $20 \%$ of the intact particles showed negative percentage change in ${ }^{154} \mathrm{Eu}$ activity post-test. Again, this behavior supports the conclusion that no uniform ${ }^{154} \mathrm{Eu}$ release is observed at $1,150^{\circ} \mathrm{C}$ over the exposure times explored.

Individual particle variations were observed. Three particles showed percentage change in ${ }^{154} \mathrm{Eu}$ activity beyond the magnitude of the maximum positive percentage change observed for comparative pre-test/post-test analysis of ${ }^{154} \mathrm{Eu}$ (e.g. >-6\%). Particle 542-P04 (-10\%) and 542-P15 (-8\%) was observed in $1,300^{\circ} \mathrm{C}, 100 \mathrm{~h}$, while particles $542-\mathrm{P} 53(-6 \%)$ and 542-P55 $(-12 \%)$ were observed in the $1,300^{\circ} \mathrm{C}, 985$ $\mathrm{h}$ test. The maximum observed increase $(+)$ change in ${ }^{154} \mathrm{Eu}$ inventory was $+6 \%$. This suggests that the decrease in inventory observed for 542-P53 (-6\%) are not outside of the statistical uncertainty, whereas 542-P04 (-10\%), 542-P15 (-8\%), and 542-P55 (-12\%) may have released some of its ${ }^{154}$ Eu inventory. The measured percentage change after exposure for particle 542-P04 (-10\%) and 542-P55 (-12\%) were both outside of one standard deviation from the mean for the particle subset, which, provides additional support for possible release. The $1,300^{\circ} \mathrm{C}, 1,500 \mathrm{~h}$ exposure showed particles with the highest relative release (i.e., more negative percentage change in pre-test versus post-test activity) for ${ }^{106} \mathrm{Ru}$ and ${ }^{125} \mathrm{Sb}$. Particle 542-P138 showed a $-5 \%$ change in ${ }^{125} \mathrm{Sb}$ activity, whereas particles $542-\mathrm{P} 139$ showed a $-8 \%$ change in ${ }^{125} \mathrm{Sb}$ activity and a $-5 \%$ change in ${ }^{106} \mathrm{Ru}$ activity at $1,300{ }^{\circ} \mathrm{C}, 1,500 \mathrm{~h}$. The negative change in activity is likely within the uncertainty of the analysis, as maximum positive values of $+12 \%$ and $+8 \%$ were observed for ${ }^{125} \mathrm{Sb}$ and ${ }^{106} \mathrm{Ru}$, respectively. All of the particles of interest had no significant variation in cesium inventory, indicating that the possible release was not due to particle failure. Particle 542-P46 represents an outiler particle as all measured fission products showed a relative increase in activity after thermal exposure. The magnitude of the increase for ${ }^{106} \mathrm{Ru},{ }^{125} \mathrm{Sb},{ }^{134} \mathrm{Cs},{ }^{137} \mathrm{Cs}$, and ${ }^{154} \mathrm{Eu}$ ranged from $+12-20 \%$, while ${ }^{144} \mathrm{Ce}$ was $+5 \%$. This general increase for isotopes is beyond the maximum positive percentage change observed in any other particles, except for ${ }^{144} \mathrm{Ce}$, and suggests the behavior is not resultant at of any other particles examined. Possible tramp contamination or a change in the background during counting of this particle may be responsible for the abnormal observation. 
Table 7. Pre- and post-test $A_{i}$ analysis for $1,300^{\circ} \mathrm{C}, 100 \mathrm{~h}$ FITT run

\begin{tabular}{|c|c|c|c|c|c|c|c|c|c|c|c|c|c|c|c|c|c|c|}
\hline \multicolumn{19}{|c|}{ Pre-test $A_{i}\left(\mathrm{~Bq} /\right.$ particle) $\mid$ Post-test $A_{i}(\mathrm{~Bq} /$ particle $) \mid \%$ Change in $A_{i}$} \\
\hline \multirow{2}{*}{$\begin{array}{l}\text { Particle } \\
\text { 542-P04 }\end{array}$} & \multicolumn{3}{|c|}{${ }^{106} \mathrm{Ru} A_{i}\left(\times 10^{7}\right)$} & \multicolumn{3}{|c|}{${ }^{125} \mathrm{Sb} A_{i}\left(\times 10^{5}\right)$} & \multicolumn{3}{|c|}{${ }^{134} \mathrm{Cs} A_{i}\left(\times 10^{6}\right)$} & \multicolumn{3}{|c|}{${ }^{137} \mathrm{Cs} A_{i}\left(\times 10^{6}\right)$} & \multicolumn{3}{|c|}{${ }^{144} \mathrm{Ce} A_{i}\left(\times 10^{7}\right)$} & \multicolumn{3}{|c|}{${ }^{154} \mathbf{E u} A_{i}\left(\times 10^{5}\right)$} \\
\hline & 1.35 & 1.37 & $1 \%$ & 2.43 & 2.33 & $-4 \%$ & 5.21 & 5.33 & $2 \%$ & 4.94 & 4.81 & $-3 \%$ & 4.14 & 4.31 & $4 \%$ & 1.77 & 1.59 & $-10 \%$ \\
\hline 542-P05 & 1.63 & 1.63 & $0 \%$ & 2.73 & 2.74 & $0 \%$ & 5.77 & 5.82 & $1 \%$ & 5.51 & 5.36 & $-3 \%$ & 4.68 & 4.88 & $4 \%$ & 1.96 & 1.89 & $-4 \%$ \\
\hline 542-P09 & 1.57 & 1.58 & $1 \%$ & 2.62 & 2.73 & $4 \%$ & 5.59 & 5.36 & $-4 \%$ & 5.45 & 5.24 & $-4 \%$ & 4.57 & 4.69 & $3 \%$ & 1.92 & 1.81 & $-6 \%$ \\
\hline $542-\mathrm{P} 12$ & 1.67 & 1.67 & $0 \%$ & 2.80 & 2.82 & $1 \%$ & 5.50 & 5.59 & $2 \%$ & 5.61 & 5.41 & $-3 \%$ & 5.28 & 5.35 & $1 \%$ & 1.80 & 1.73 & $-3 \%$ \\
\hline $542-\mathrm{P} 13$ & 1.67 & 1.67 & $0 \%$ & 2.77 & 2.74 & $-1 \%$ & 5.81 & 5.86 & $1 \%$ & 5.57 & 5.33 & $-4 \%$ & 4.96 & 5.18 & $5 \%$ & 1.90 & 1.88 & $-1 \%$ \\
\hline 542-P15 & 1.41 & 1.40 & $\mathbf{0} \%$ & 2.38 & 2.29 & $-4 \%$ & 4.35 & 4.37 & $0 \%$ & 4.56 & 4.25 & $-7 \%$ & 4.73 & 4.79 & $1 \%$ & 1.43 & 1.32 & $-8 \%$ \\
\hline $542-\mathrm{P} 22$ & 1.73 & 1.72 & $-1 \%$ & 2.92 & 2.97 & $2 \%$ & 6.35 & 6.39 & $1 \%$ & 5.84 & 5.59 & $-4 \%$ & 4.65 & 4.77 & $3 \%$ & 2.04 & 2.02 & $-1 \%$ \\
\hline 542-P24 & 1.46 & 1.44 & $-1 \%$ & 2.49 & 2.41 & $-3 \%$ & 5.57 & 5.55 & $0 \%$ & 5.30 & 5.02 & $-5 \%$ & 4.58 & 4.55 & $-1 \%$ & 1.83 & 1.72 & $-6 \%$ \\
\hline $542-\mathrm{P} 26$ & 1.45 & 1.44 & $-1 \%$ & 2.37 & 2.42 & $2 \%$ & 4.43 & 4.39 & $-1 \%$ & 4.68 & 4.43 & $-5 \%$ & 5.02 & 5.08 & $1 \%$ & 1.44 & 1.35 & $-6 \%$ \\
\hline 542-P27 & 1.65 & 1.65 & $0 \%$ & 2.76 & 2.83 & $3 \%$ & 5.79 & 5.83 & $1 \%$ & 5.61 & 5.39 & $-4 \%$ & 4.91 & 5.10 & $4 \%$ & 1.81 & 1.86 & $3 \%$ \\
\hline Maximum & 1.73 & 1.72 & $1 \%$ & 2.92 & 2.97 & $4 \%$ & 6.35 & 6.39 & $2 \%$ & 5.84 & 5.59 & $-3 \%$ & 5.28 & 5.35 & $5 \%$ & 2.04 & 2.02 & $3 \%$ \\
\hline Minimum & 1.35 & 1.37 & $-1 \%$ & 2.37 & 2.29 & $-4 \%$ & 4.35 & 4.37 & $-4 \%$ & 4.56 & 4.25 & $-7 \%$ & 4.14 & 4.31 & $-1 \%$ & 1.43 & 1.32 & $-10 \%$ \\
\hline Mean & 1.56 & 1.56 & $0 \%$ & 2.63 & 2.63 & $0 \%$ & 5.44 & 5.45 & $0 \%$ & 5.31 & 5.08 & $-4 \%$ & 4.75 & 4.87 & $3 \%$ & 1.79 & 1.72 & $-4 \%$ \\
\hline Std Dev ( \pm ) & 0.00 & 0.00 & $1 \%$ & 0.00 & 0.00 & $3 \%$ & 0.00 & 0.00 & $2 \%$ & 0.00 & 0.00 & $1 \%$ & 0.00 & 0.00 & $2 \%$ & 0.00 & 0.00 & $4 \%$ \\
\hline
\end{tabular}

Table 8. Pre- and post-test $A_{i}$ analysis for $1,300^{\circ} \mathrm{C}, 500 \mathrm{~h}$ FITT run

\begin{tabular}{|c|c|c|c|c|c|c|c|c|c|c|c|c|c|c|c|c|c|c|}
\hline \multicolumn{19}{|c|}{ Pre-test $A_{i}(\mathrm{~Bq} /$ particle $) \mid$ Post-test $A_{i}(\mathrm{~Bq} /$ particle $) \mid \%$ Change in $A_{i}$} \\
\hline \multirow{2}{*}{$\begin{array}{l}\text { Particle } \\
542-\mathrm{P} 49\end{array}$} & \multicolumn{3}{|c|}{${ }^{106} \mathrm{Ru} A_{i}\left(\times 10^{7}\right)$} & \multicolumn{3}{|c|}{${ }^{125} \mathrm{Sb} A_{i}\left(\times 10^{5}\right)$} & \multicolumn{3}{|c|}{${ }^{134} \mathrm{Cs} A_{i}\left(\times 10^{6}\right)$} & \multicolumn{3}{|c|}{${ }^{137} \mathrm{Cs} A_{i}\left(\times 10^{6}\right)$} & \multicolumn{3}{|c|}{${ }^{144} \mathrm{Ce} A_{i}\left(\times 10^{7}\right)$} & \multicolumn{3}{|c|}{${ }^{154} \mathbf{E u} A_{i}\left(\times 10^{5}\right)$} \\
\hline & 1.97 & 1.91 & $-3 \%$ & 3.18 & 3.26 & $3 \%$ & 7.16 & 7.10 & $-1 \%$ & 6.50 & 6.13 & $-6 \%$ & 5.14 & 5.18 & $1 \%$ & 2.42 & 2.25 & $-7 \%$ \\
\hline $542-\mathrm{P} 50$ & 1.59 & 1.54 & $-3 \%$ & 2.62 & 2.64 & $1 \%$ & 5.37 & 5.42 & $1 \%$ & 5.32 & 5.01 & $-6 \%$ & 4.75 & 4.76 & $0 \%$ & 1.78 & 1.74 & $-2 \%$ \\
\hline 542-P52 & 1.44 & 1.42 & $-2 \%$ & 2.42 & 2.43 & $1 \%$ & 4.86 & 5.07 & $4 \%$ & 5.04 & 5.06 & $0 \%$ & 4.86 & 4.56 & $-6 \%$ & 1.72 & 1.67 & $-3 \%$ \\
\hline 542-P56 & 1.49 & 1.52 & $2 \%$ & 2.56 & 2.58 & $1 \%$ & 5.59 & 5.69 & $2 \%$ & 5.53 & 5.51 & $0 \%$ & 4.98 & 4.74 & $-5 \%$ & 1.86 & 1.81 & $-3 \%$ \\
\hline 542-P60 & 1.51 & 1.46 & $-4 \%$ & 2.57 & 2.58 & $0 \%$ & 4.91 & 4.88 & $-1 \%$ & 5.20 & 5.19 & $0 \%$ & 5.42 & 5.35 & $-1 \%$ & 1.52 & 1.60 & $5 \%$ \\
\hline 542-P64 & 1.59 & 1.56 & $-2 \%$ & 2.70 & 2.76 & $2 \%$ & 5.87 & 5.64 & $-4 \%$ & 5.81 & 5.78 & $-1 \%$ & 5.38 & 5.06 & $-6 \%$ & 1.90 & 1.90 & $0 \%$ \\
\hline 542-P65 & 1.62 & 1.57 & $-3 \%$ & 2.71 & 2.92 & $8 \%$ & 5.66 & 5.62 & $-1 \%$ & 5.79 & 5.79 & $0 \%$ & 5.41 & 5.16 & $-5 \%$ & 1.91 & 1.83 & $-4 \%$ \\
\hline 542-P67 & 1.38 & 1.37 & $-1 \%$ & 2.33 & 2.33 & $0 \%$ & 4.92 & 4.87 & $-1 \%$ & 4.93 & 4.89 & $-1 \%$ & 4.69 & 4.50 & $-4 \%$ & 1.59 & 1.54 & $-3 \%$ \\
\hline 542-P68 & 1.71 & 1.70 & $-1 \%$ & 2.90 & 2.92 & $1 \%$ & 6.06 & 6.13 & $1 \%$ & 5.89 & 5.93 & $1 \%$ & 5.22 & 5.10 & $-2 \%$ & 1.98 & 2.00 & $1 \%$ \\
\hline 542-P69 & 1.43 & 1.37 & $-4 \%$ & 2.46 & 2.51 & $2 \%$ & 5.24 & 5.25 & $0 \%$ & 5.14 & 5.11 & $0 \%$ & 4.81 & 4.61 & $-4 \%$ & 1.73 & 1.67 & $-3 \%$ \\
\hline Maximum & 1.97 & 1.91 & $2 \%$ & 3.18 & 3.26 & $8 \%$ & 7.16 & 7.10 & $4 \%$ & 6.50 & 6.13 & $1 \%$ & 5.42 & 5.35 & $1 \%$ & 2.42 & 2.25 & $5 \%$ \\
\hline Minimum & 1.38 & 1.37 & $-4 \%$ & 2.33 & 2.33 & $0 \%$ & 4.86 & 4.87 & $-4 \%$ & 4.93 & 4.89 & $-6 \%$ & 4.69 & 4.50 & $-6 \%$ & 1.52 & 1.54 & $-7 \%$ \\
\hline Mean & 1.57 & 1.54 & $-2 \%$ & 2.64 & 2.69 & $2 \%$ & 5.56 & 5.57 & $0 \%$ & 5.51 & 5.44 & $-1 \%$ & 5.07 & 4.90 & $-3 \%$ & 1.84 & 1.80 & $-2 \%$ \\
\hline Std Dev ( \pm ) & 0.17 & 0.16 & $2 \%$ & 0.25 & 0.28 & $2 \%$ & 0.70 & 0.67 & $2 \%$ & 0.48 & 0.44 & $2 \%$ & 0.28 & 0.30 & $2 \%$ & 0.25 & 0.21 & $3 \%$ \\
\hline
\end{tabular}


Table 9. Pre- and post-test $A_{i}$ analysis for $1,300^{\circ} \mathrm{C}, 985 \mathrm{~h}$ FITT run

\begin{tabular}{|c|c|c|c|c|c|c|c|c|c|c|c|c|c|c|c|c|c|c|}
\hline \multicolumn{19}{|c|}{ Pre-test $A_{i}(\mathrm{~Bq} /$ particle $) \mid$ Post-test $A_{i}(\mathrm{~Bq} /$ particle $) \mid \%$ Change in $A_{i}$} \\
\hline \multirow{2}{*}{$\begin{array}{l}\text { Particle } \\
542-P 36\end{array}$} & \multicolumn{3}{|c|}{${ }^{106} \mathrm{Ru} A_{i}\left(\times 10^{7}\right)$} & \multicolumn{3}{|c|}{${ }^{125} \mathrm{Sb} A_{i}\left(\times 10^{5}\right)$} & \multicolumn{3}{|c|}{${ }^{134} \mathrm{Cs} A_{i}\left(\times 10^{6}\right)$} & \multicolumn{3}{|c|}{${ }^{137} \mathrm{Cs} A_{i}\left(\times 10^{6}\right)$} & \multicolumn{3}{|c|}{${ }^{144} \mathrm{Ce} A_{i}\left(\times 10^{7}\right)$} & \multicolumn{3}{|c|}{${ }^{154} \mathrm{Eu} A_{i}\left(\times 10^{5}\right)$} \\
\hline & 1.68 & 1.23 & $-27 \%$ & 2.80 & 0.10 & $-96 \%$ & 6.05 & 0.01 & $-100 \%$ & 5.96 & 0.01 & $-100 \%$ & 5.27 & 4.25 & $-19 \%$ & 1.98 & 0.65 & $-67 \%$ \\
\hline 542-P37 & 1.52 & 1.55 & $1 \%$ & 2.53 & 2.60 & $3 \%$ & 5.05 & 5.18 & $3 \%$ & 5.23 & 5.27 & $1 \%$ & 5.29 & 5.22 & $-1 \%$ & 1.57 & 1.66 & $6 \%$ \\
\hline 542-P38 & 1.70 & 1.71 & $1 \%$ & 2.84 & 2.93 & $3 \%$ & 5.37 & 5.37 & $0 \%$ & 5.61 & 5.58 & $-1 \%$ & 5.81 & 5.76 & $-1 \%$ & 1.69 & 1.67 & $-1 \%$ \\
\hline 542-P45 & 1.58 & 1.56 & $-1 \%$ & 2.82 & 2.81 & $-1 \%$ & 5.89 & 5.95 & $1 \%$ & 5.84 & 5.80 & $-1 \%$ & 5.45 & 5.27 & $-3 \%$ & 1.96 & 1.88 & $-4 \%$ \\
\hline 542-P46 & 1.48 & 1.68 & $14 \%$ & 2.53 & 2.82 & $12 \%$ & 5.01 & 6.00 & $20 \%$ & 5.15 & 5.93 & $15 \%$ & 5.20 & 5.43 & $5 \%$ & 1.62 & 1.87 & $15 \%$ \\
\hline 542-P51 & 1.49 & 1.49 & $0 \%$ & 2.45 & 2.52 & $3 \%$ & 4.59 & 4.70 & $2 \%$ & 4.96 & 4.96 & $0 \%$ & 5.52 & 5.32 & $-4 \%$ & 1.54 & 1.51 & $-2 \%$ \\
\hline 542-P53 & 1.55 & 1.55 & $\mathbf{0 \%}$ & 2.69 & 2.71 & $1 \%$ & 5.78 & 5.88 & $2 \%$ & 5.70 & 5.73 & $1 \%$ & 5.16 & 5.05 & $-2 \%$ & 1.95 & 1.84 & $-6 \%$ \\
\hline 542-P54 & 1.68 & 1.74 & $3 \%$ & 2.72 & 2.75 & $1 \%$ & 4.55 & 5.00 & $10 \%$ & 5.23 & 5.21 & $0 \%$ & 5.77 & 5.57 & $-3 \%$ & 1.62 & 1.57 & $-3 \%$ \\
\hline 542-P55 & 1.63 & 1.59 & $-2 \%$ & 2.80 & 2.90 & $4 \%$ & 6.09 & 6.15 & $1 \%$ & 6.08 & 6.03 & $-1 \%$ & 5.66 & 5.37 & $-5 \%$ & 2.04 & 1.80 & $-12 \%$ \\
\hline 542-P57 & 1.60 & 1.57 & $-2 \%$ & 2.57 & 2.73 & $6 \%$ & 5.43 & 5.48 & $1 \%$ & 5.40 & 5.36 & $-1 \%$ & 4.94 & 4.63 & $-6 \%$ & 1.80 & 1.76 & $-2 \%$ \\
\hline Maximum & 1.70 & 1.74 & $3 \%$ & 2.84 & 2.93 & $6 \%$ & 6.09 & 6.15 & $10 \%$ & 6.08 & 6.03 & $1 \%$ & 5.81 & 5.76 & $-1 \%$ & 2.04 & 1.88 & $6 \%$ \\
\hline Minimum & 1.48 & 1.49 & $-2 \%$ & 2.45 & 2.52 & $-1 \%$ & 4.55 & 4.70 & $0 \%$ & 4.96 & 4.96 & $-1 \%$ & 4.94 & 4.63 & $-6 \%$ & 1.54 & 1.51 & $-12 \%$ \\
\hline Mean & 1.59 & 1.60 & $0 \%$ & 2.67 & 2.75 & $2 \%$ & 5.38 & 5.52 & $2 \%$ & 5.52 & 5.54 & $0 \%$ & 5.41 & 5.29 & $-3 \%$ & 1.78 & 1.73 & $-3 \%$ \\
\hline Std Dev ( $( \pm)$ & 0.08 & 0.09 & $2 \%$ & 0.15 & 0.14 & $2 \%$ & 0.57 & 0.50 & $3 \%$ & 0.38 & 0.35 & $1 \%$ & 0.28 & 0.34 & $2 \%$ & 0.19 & 0.13 & $5 \%$ \\
\hline
\end{tabular}

Table 10. Pre- and post-test $A_{i}$ analysis for $1,300^{\circ} \mathrm{C}, 1,500 \mathrm{~h}$ FITT run

\begin{tabular}{|c|c|c|c|c|c|c|c|c|c|c|c|c|c|c|c|c|c|c|}
\hline \multirow{3}{*}{$\begin{array}{c}\text { Particle } \\
542-\mathrm{P} 131 \\
\end{array}$} & \multicolumn{18}{|c|}{ Pre-test $A_{i}(\mathrm{~Bq} /$ particle $) \mid$ Post-test $A_{i}(\mathrm{~Bq} /$ particle $) \mid \%$ Change in $A_{i}$} \\
\hline & \multicolumn{3}{|c|}{${ }^{106} \mathrm{Ru} A_{i}\left(\times 10^{7}\right)$} & \multicolumn{3}{|c|}{${ }^{125} \mathrm{Sb} A_{i}\left(\times 10^{5}\right)$} & \multicolumn{3}{|c|}{${ }^{134} \operatorname{Cs} A_{i}\left(\times 10^{6}\right)$} & \multicolumn{3}{|c|}{${ }^{137} \mathrm{Cs} A_{i}\left(\times 10^{6}\right)$} & \multicolumn{3}{|c|}{${ }^{144} \mathrm{Ce} A_{i}\left(\times 10^{7}\right)$} & \multicolumn{3}{|c|}{${ }^{154} \mathbf{E u} A_{i}\left(\times 10^{5}\right)$} \\
\hline & 1.39 & 1.51 & $8 \%$ & 2.42 & 2.71 & $12 \%$ & 4.67 & 4.75 & $2 \%$ & 4.80 & 4.95 & $3 \%$ & 5.34 & 5.36 & $0 \%$ & 1.48 & 1.50 & $1 \%$ \\
\hline 542-P132 & 1.52 & 1.57 & $4 \%$ & 2.75 & 2.65 & $-4 \%$ & 5.76 & 5.85 & $1 \%$ & 5.66 & 5.81 & $3 \%$ & 5.12 & 5.23 & $2 \%$ & 1.79 & 1.80 & $0 \%$ \\
\hline $542-\mathrm{P} 133$ & 1.68 & 1.68 & $0 \%$ & 2.82 & 2.97 & $5 \%$ & 5.87 & 6.03 & $3 \%$ & 5.74 & 5.93 & $3 \%$ & 4.99 & 5.03 & $1 \%$ & 1.91 & 1.90 & $-1 \%$ \\
\hline 542-P134 & 1.46 & 1.48 & $2 \%$ & 2.66 & 2.65 & $0 \%$ & 5.33 & 5.43 & $2 \%$ & 5.28 & 5.40 & $2 \%$ & 5.29 & 5.42 & $2 \%$ & 1.70 & 1.73 & $2 \%$ \\
\hline $542-\mathrm{P} 135$ & 1.69 & 1.80 & $6 \%$ & 3.02 & 3.13 & $4 \%$ & 6.41 & 6.60 & $3 \%$ & 6.12 & 6.34 & $4 \%$ & 5.25 & 5.67 & $8 \%$ & 2.12 & 2.11 & $0 \%$ \\
\hline $542-\mathrm{P} 136$ & 1.58 & 1.58 & $0 \%$ & 2.64 & 2.80 & $6 \%$ & 5.33 & 5.45 & $2 \%$ & 5.40 & 5.52 & $2 \%$ & 4.94 & 4.89 & $-1 \%$ & 1.77 & 1.76 & $0 \%$ \\
\hline $542-\mathrm{P} 137$ & 1.60 & 1.65 & $3 \%$ & 2.72 & 2.85 & $5 \%$ & 4.90 & 5.05 & $3 \%$ & 5.24 & 5.48 & $4 \%$ & 5.95 & 6.24 & $5 \%$ & 1.58 & 1.57 & $-1 \%$ \\
\hline 542-P138 & 1.46 & 1.50 & $3 \%$ & 2.71 & 2.57 & $-5 \%$ & 5.44 & 5.57 & $2 \%$ & 5.21 & 5.37 & $3 \%$ & 4.61 & 4.73 & $3 \%$ & 1.75 & 1.81 & $3 \%$ \\
\hline 542-P139 & 1.56 & 1.48 & $-5 \%$ & 2.97 & 2.74 & $-8 \%$ & 5.86 & 6.05 & $3 \%$ & 5.59 & 5.79 & $4 \%$ & 4.98 & 5.26 & $6 \%$ & 1.89 & 1.93 & $2 \%$ \\
\hline $542-\mathrm{P} 140$ & 1.55 & 1.57 & $1 \%$ & 2.60 & 2.83 & $9 \%$ & 5.16 & 5.34 & $3 \%$ & 5.13 & 5.29 & $3 \%$ & 5.05 & 5.29 & $5 \%$ & 1.69 & 1.71 & $1 \%$ \\
\hline Maximum & 1.69 & 1.80 & $8 \%$ & 3.02 & 3.13 & $12 \%$ & 6.41 & 6.60 & $3 \%$ & 6.12 & 6.34 & $4 \%$ & 5.95 & 6.24 & $8 \%$ & 2.12 & 2.11 & $3 \%$ \\
\hline Minimum & 1.39 & 1.48 & $-5 \%$ & 2.42 & 2.57 & $-8 \%$ & 4.67 & 4.75 & $1 \%$ & 4.80 & 4.95 & $2 \%$ & 4.61 & 4.73 & $-1 \%$ & 1.48 & 1.50 & $-1 \%$ \\
\hline Mean & 1.55 & 1.58 & $2 \%$ & 2.73 & 2.79 & $2 \%$ & 5.47 & 5.61 & $3 \%$ & 5.42 & 5.59 & $3 \%$ & 5.15 & 5.31 & $3 \%$ & 1.77 & 1.78 & $1 \%$ \\
\hline Std Dev ( $( \pm)$ & 0.09 & 0.10 & $4 \%$ & 0.18 & 0.17 & $6 \%$ & 0.51 & 0.54 & $1 \%$ & 0.37 & 0.39 & $1 \%$ & 0.35 & 0.42 & $3 \%$ & 0.18 & 0.17 & $1 \%$ \\
\hline
\end{tabular}


The measured activity for ${ }^{106} \mathrm{Ru},{ }^{125} \mathrm{Sb},{ }^{134} \mathrm{Cs},{ }^{137} \mathrm{Cs},{ }^{144} \mathrm{Ce}$, and ${ }^{154} \mathrm{Eu}$ for the $1,600{ }^{\circ} \mathrm{C}$ test conditions are reported in However, this was within the bound of the maximum positive deviation of ${ }^{125 \mathrm{Sb}}$ measured from comparative analysis $(+12 \%)$. All of the particles of interest had no significant variation in cesium inventory, indicating that the possible release was not due to particle failure.

Table 11 through Table 12 . No results are reported for the $1,600^{\circ} \mathrm{C}$ analyses at 1,000 and $1,500 \mathrm{~h}$, as no particles were recovered due to failure of the external ceramic tube during operation, as discussed in Section 5.3. No obvious indication of uniform additional release of ${ }^{106} \mathrm{Ru},{ }^{125} \mathrm{Sb},{ }^{134} \mathrm{Cs},{ }^{137} \mathrm{Cs}$, ${ }^{144} \mathrm{Ce}$, and

${ }^{154} \mathrm{Eu}$ was determined from the pre-test and post-test activity comparison. This is based on the observations that the mean percentage change (pre- and post-test comparison) was generally $-2-4 \%$ which is within the expected uncertainty. Similar to the $1,150^{\circ} \mathrm{C}$ and $1,300^{\circ} \mathrm{C}$ exposures series no general trend of decreasing mean percentage change in post-test activity was observed for the longer exposure.

Individual particle variations were observed for select particles from the $1,600^{\circ} \mathrm{C}$ exposures. Particle $542-\mathrm{P} 106\left(1,600^{\circ} \mathrm{C}, 84 \mathrm{~h}\right)$ showed a $-8 \%$ decrease in ${ }^{154} \mathrm{Eu}$ activity post-test, which was outside of one standard deviation from the mean for the particle subset. It was also beyond the maximum positive deviation of ${ }^{154} \mathrm{Eu}$ measured from comparative analysis $(+6 \%)$. Therefore, the ${ }^{154} \mathrm{Eu}$ post-test activity variation may be indicative of release. Particles 542-P58 and 542-P115 showed -10\% and -7\% change in ${ }^{125} \mathrm{Sb}$ activity post-test respectively. However, this was within the bound of the maximum positive deviation of ${ }^{125} \mathrm{Sb}$ measured from comparative analysis $(+12 \%)$. All of the particles of interest had no significant variation in cesium inventory, indicating that the possible release was not due to particle failure.

Table 11. Pre- and post-test $A_{i}$ analysis for $1,600^{\circ} \mathrm{C}, 84 \mathrm{~h}$ FITT run

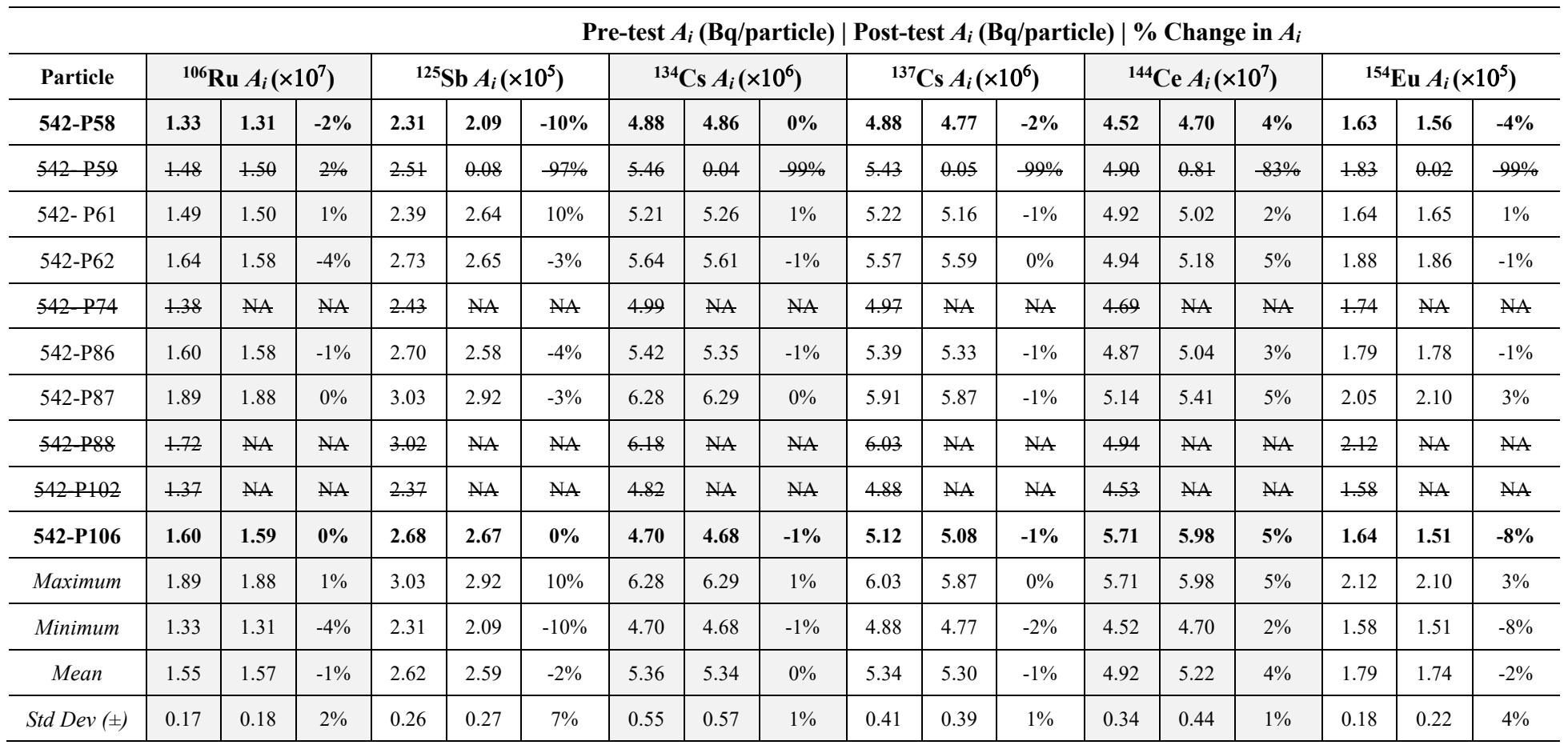


Table 12. Pre- and Post-test $A_{i}$ analysis for $1,600^{\circ} \mathrm{C}, 500 \mathrm{~h}$ FITT run

\begin{tabular}{|c|c|c|c|c|c|c|c|c|c|c|c|c|c|c|c|c|c|c|}
\hline \multicolumn{19}{|c|}{ Pre-test $\mathrm{A}_{\mathrm{i}}\left(\mathrm{Bq} /\right.$ particle) $\mid$ Post-test $A_{i}(\mathrm{~Bq} /$ particle $) \mid \%$ Change in $A_{i}$} \\
\hline \multirow{2}{*}{$\begin{array}{c}\text { Particle } \\
542-\mathrm{P} 107\end{array}$} & \multicolumn{3}{|c|}{${ }^{106} \mathrm{Ru} A_{i}\left(\times 10^{7}\right)$} & \multicolumn{3}{|c|}{${ }^{125} \mathrm{Sb} A_{i}\left(\times 10^{5}\right)$} & \multicolumn{3}{|c|}{${ }^{134} \mathrm{Cs} A_{i}\left(\times 10^{6}\right)$} & \multicolumn{3}{|c|}{${ }^{137} \mathrm{Cs} A_{i}\left(\times 10^{6}\right)$} & \multicolumn{3}{|c|}{${ }^{144} \mathrm{Ce} A_{i}\left(\times 10^{7}\right)$} & \multicolumn{3}{|c|}{${ }^{154} \mathrm{Eu} A_{i}\left(\times 10^{5}\right)$} \\
\hline & 1.63 & 1.57 & $-4 \%$ & 2.94 & 2.83 & $-4 \%$ & 5.86 & 6.06 & $3 \%$ & 5.70 & 5.79 & $2 \%$ & 5.25 & 5.25 & $0 \%$ & 1.94 & 1.90 & $-2 \%$ \\
\hline 542-P108 & 1.69 & 1.70 & $0 \%$ & 2.95 & 2.92 & $-1 \%$ & 6.05 & 6.24 & $3 \%$ & 5.83 & 5.85 & $0 \%$ & 4.81 & 4.89 & $2 \%$ & 2.06 & 2.01 & $-2 \%$ \\
\hline 542-P109 & 1.55 & 1.58 & $2 \%$ & 2.67 & 2.65 & $-1 \%$ & 5.02 & 4.98 & $-1 \%$ & 5.15 & 5.14 & $0 \%$ & 5.60 & 5.67 & $1 \%$ & 1.60 & 1.63 & $1 \%$ \\
\hline 542 P110 & 1.63 & NA & NA & 2.88 & NA & NA & 5.94 & NA & NA & 5.89 & NA & NA & 5.42 & NA & NA & 1.95 & NA & NA \\
\hline $542-\mathrm{P} 111$ & 1.47 & 1.38 & $-6 \%$ & 2.37 & 2.46 & $4 \%$ & 5.25 & 5.17 & $-1 \%$ & 5.03 & 5.01 & $0 \%$ & 4.60 & 4.58 & $0 \%$ & 1.67 & 1.68 & $0 \%$ \\
\hline 542-P112 & 1.56 & 1.53 & $-2 \%$ & 2.68 & 2.80 & $4 \%$ & 5.62 & 5.69 & $1 \%$ & 5.60 & 5.58 & $0 \%$ & 5.44 & 5.09 & $-6 \%$ & 1.86 & 1.83 & $-2 \%$ \\
\hline $542 \mathrm{P} 113$ & 1.63 & NA & NA & 2.84 & NA & NA & 5.45 & NA & NA & 5.36 & $\mathrm{NA}$ & $\mathrm{NA}$ & 5.04 & NA & NA & 1.79 & $\mathrm{NA}$ & $\mathrm{NA}$ \\
\hline 542-P114 & 1.56 & 1.51 & $-3 \%$ & 2.70 & 2.58 & $-4 \%$ & 4.96 & 5.09 & $3 \%$ & 5.19 & 5.23 & $1 \%$ & 5.12 & 5.04 & $-1 \%$ & 1.64 & 1.65 & $1 \%$ \\
\hline 542-P115 & 1.63 & 1.67 & $3 \%$ & 2.84 & 2.63 & $-7 \%$ & 5.79 & 5.70 & $-2 \%$ & 5.56 & 5.55 & $0 \%$ & 5.09 & 4.92 & $-3 \%$ & 1.85 & 1.86 & $1 \%$ \\
\hline 542-P116 & 1.51 & 1.47 & $-3 \%$ & 2.62 & 2.57 & $-2 \%$ & 5.39 & 5.61 & $4 \%$ & 5.38 & 5.43 & $1 \%$ & 5.14 & 5.44 & $6 \%$ & 1.76 & 1.78 & $1 \%$ \\
\hline Maximum & 1.69 & 1.70 & $3 \%$ & 2.95 & 2.92 & $4 \%$ & 6.05 & 6.24 & $4 \%$ & 5.89 & 5.85 & $2 \%$ & 5.60 & 5.67 & $6 \%$ & 2.06 & 2.01 & $1 \%$ \\
\hline Minimum & 1.47 & 1.38 & $-6 \%$ & 2.37 & 2.46 & $-7 \%$ & 4.96 & 4.98 & $-2 \%$ & 5.03 & 5.01 & $0 \%$ & 4.60 & 4.58 & $-6 \%$ & 1.60 & 1.63 & $-2 \%$ \\
\hline Mean & 1.59 & 1.55 & $-2 \%$ & 2.75 & 2.68 & $-1 \%$ & 5.53 & 5.57 & $1 \%$ & 5.47 & 5.45 & $0 \%$ & 5.15 & 5.11 & $0 \%$ & 1.81 & 1.79 & $0 \%$ \\
\hline$S t d \operatorname{Dev}( \pm)$ & 0.07 & 0.10 & $3 \%$ & 0.18 & 0.15 & $4 \%$ & 0.38 & 0.46 & $2 \%$ & 0.29 & 0.30 & $1 \%$ & 0.30 & 0.34 & $4 \%$ & 0.15 & 0.13 & $2 \%$ \\
\hline
\end{tabular}

\subsection{SILVER RELEASE ANALYSIS}

The analysis of silver release $\left({ }^{110 \mathrm{~m}} \mathrm{Ag}\right)$ is of primary interest due to the extent of silver release observed during irradiation and the bimodal release behavior observed during safety testing. Silver analysis is a challenge due to (1) the low yield relative to other gamma-emitting fission products analyzed such as ${ }^{134} \mathrm{Cs}$ and (2) the impact of decay on the analysis over the course of a PIE campaign. The half-life of ${ }^{110 \mathrm{~m}} \mathrm{Ag}$ is $\sim 249.8$ days. The first thermal exposure tests were conducted $\sim 1,573$ days after the AGR-2 experiment was removed from the reactor (October of 2013). As such, ${ }^{110 \mathrm{~m}} \mathrm{Ag}$ had undergone $\sim 6.3 \mathrm{half}-$ lives. The decay coupled with low-yield results in increased uncertainty due to increasingly fewer counts above background overtime.

Silver inventory analysis was captured for the first four exposure conditions analyzed: $1,150^{\circ} \mathrm{C}$ at 100 $500 \mathrm{~h}$, and $1,300^{\circ} \mathrm{C}$ at $100-500 \mathrm{~h}$ (Table 13 through Table 16$)$. The measured ${ }^{110 \mathrm{~m}} \mathrm{Ag}$ activity (Bq/particle) and ${ }^{110 \mathrm{~m}} \mathrm{Ag} \mathrm{A} / \mathrm{C}$ are reported for each test condition. The uncertainty in the gamma peak analysis is also reported (one standard deviation), along with uncertainty in ${ }^{110 \mathrm{~m}} \mathrm{Ag} \mathrm{A} / \mathrm{C}$ calculation (one standard deviation), for post-test particles for which the remaining activity was below the minimum quantifiable limit $\left(\mathrm{L}_{\mathrm{Q}}\right)$; an upper bound estimate for the ${ }^{110 \mathrm{~m}} \mathrm{Ag} \mathrm{A} / \mathrm{C}$ was estimated from this value. 
Table 13. Pre- and post-test ${ }^{110 \mathrm{~m}} \mathrm{Ag} A_{i}$ and $\mathrm{A} / \mathrm{C}$ analysis for $1,150^{\circ} \mathrm{C}, 100 \mathrm{~h}$ FITT run

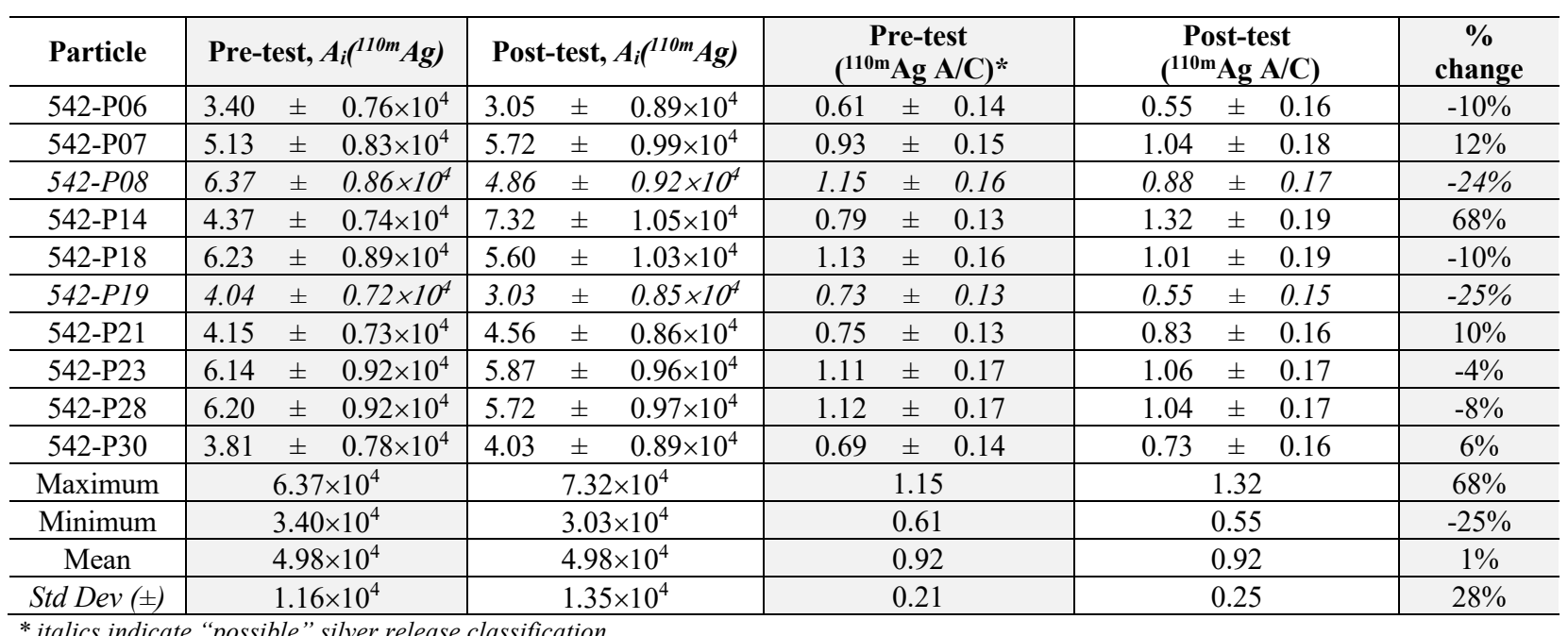

* italics indicate "possible" silver release classification

Table 14. Pre- and post-test ${ }^{110 \mathrm{~m}} \mathrm{Ag} A_{i}$ and $\mathrm{A} / \mathrm{C}$ analysis for $1,150^{\circ} \mathrm{C}, 500 \mathrm{~h}$ FITT run

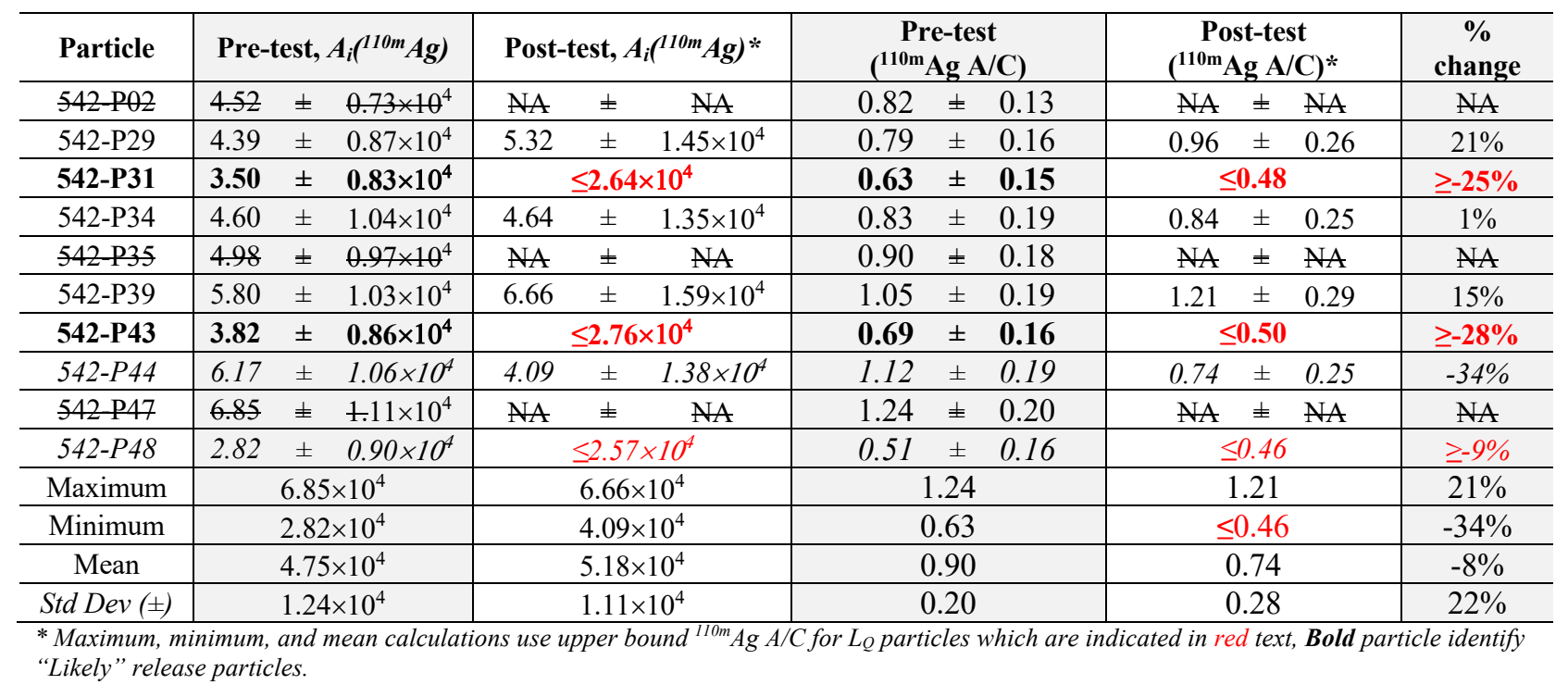


Table 15. Pre- and post-test ${ }^{110 \mathrm{~m}} \mathrm{Ag} A_{i}$ and $\mathrm{A} / \mathrm{C}$ analysis for $1,300^{\circ} \mathrm{C}, 100 \mathrm{~h}$ FITT run

\begin{tabular}{|c|c|c|c|c|c|c|c|c|c|c|c|c|c|}
\hline \multirow{2}{*}{$\begin{array}{l}\text { Particle } \\
\text { 542-P04 } \\
\end{array}$} & \multicolumn{3}{|c|}{ Pre-test, $A_{i}\left({ }^{110 m} A g\right)$} & \multicolumn{3}{|c|}{ Post-test, $A_{i}\left({ }^{110 m} A g\right)$} & \multicolumn{3}{|c|}{$\begin{array}{c}\text { Pre-test } \\
\left({ }^{110 \mathrm{~m}} \mathrm{Ag} \mathrm{A} / \mathrm{C}\right)\end{array}$} & \multicolumn{3}{|c|}{$\begin{array}{c}\text { Post-test } \\
\left({ }^{110 \mathrm{~m}} \mathrm{Ag} \mathrm{A} / \mathrm{C}\right)\end{array}$} & \multirow{2}{*}{$\begin{array}{c}\begin{array}{c}\% \\
\text { change }\end{array} \\
-71 \% \\
\end{array}$} \\
\hline & 5.84 & \pm & $0.82 \times 10^{4}$ & 1.68 & \pm & $0.68 \times 10^{4}$ & 1.06 & \pm & 0.15 & 0.30 & \pm & 0.12 & \\
\hline $542-P 05$ & 5.77 & \pm & $0.87 \times 10^{4}$ & 4.77 & \pm & $0.94 \times 10^{4}$ & 1.04 & \pm & 0.16 & 0.86 & -1 & 0.17 & $-17 \%$ \\
\hline $542-P 09$ & 4.89 & \pm & $0.86 \times 10^{4}$ & 3.80 & \pm & $0.81 \times 10^{4}$ & 0.88 & \pm & 0.16 & 0.69 & $\perp$ & 0.15 & $-22 \%$ \\
\hline $542-P 12$ & 3.44 & \pm & $0.68 \times 10^{4}$ & 2.46 & \pm & $0.91 \times 10^{4}$ & 0.62 & \pm & 0.12 & 0.45 & + & 0.16 & $-28 \%$ \\
\hline 542-P13 & 5.29 & \pm & $0.87 \times 10^{4}$ & 6.75 & \pm & $1.03 \times 10^{4}$ & 0.96 & \pm & 0.16 & 1.22 & \pm & 0.19 & $28 \%$ \\
\hline 542-P15 & 4.63 & \pm & $0.79 \times 10^{4}$ & 1.59 & \pm & $0.73 \times 10^{4}$ & 0.84 & \pm & 0.14 & 0.29 & \pm & 0.13 & $-66 \%$ \\
\hline 542-P22 & 6.19 & \pm & $0.90 \times 10^{4}$ & 6.00 & \pm & $1.06 \times 10^{4}$ & 1.12 & \pm & 0.16 & 1.09 & \pm & 0.19 & $-3 \%$ \\
\hline 542-P24 & 3.82 & \pm & $0.77 \times 10^{4}$ & 1.97 & \pm & $0.79 \times 10^{4}$ & 0.69 & \pm & 0.14 & 0.36 & \pm & 0.14 & $-48 \%$ \\
\hline 542-P26 & 3.48 & \pm & $0.79 \times 10^{4}$ & 1.63 & \pm & $0.74 \times 10^{4}$ & 0.63 & \pm & 0.14 & 0.29 & \pm & 0.13 & $-53 \%$ \\
\hline $542-P 27$ & 4.83 & \pm & $0.78 \times 10^{4}$ & 3.33 & \pm & $0.82 \times 10^{4}$ & 0.87 & \pm & 0.14 & 0.60 & \pm & 0.15 & $-31 \%$ \\
\hline Maximum & \multicolumn{3}{|c|}{$6.19 \times 10^{4}$} & \multicolumn{3}{|c|}{$6.75 \times 10^{4}$} & \multicolumn{3}{|c|}{1.12} & \multicolumn{3}{|c|}{1.22} & $28 \%$ \\
\hline Minimum & \multicolumn{3}{|c|}{$3.44 \times 10^{4}$} & \multicolumn{3}{|c|}{$1.59 \times 10^{4}$} & \multicolumn{3}{|c|}{0.62} & \multicolumn{3}{|c|}{0.29} & $-71 \%$ \\
\hline Mean & \multicolumn{3}{|c|}{$4.82 \times 10^{4}$} & \multicolumn{3}{|c|}{$3.40 \times 10^{4}$} & \multicolumn{3}{|c|}{0.87} & \multicolumn{3}{|c|}{0.62} & $-31 \%$ \\
\hline $\operatorname{Std} \operatorname{Dev}( \pm)$ & \multicolumn{3}{|c|}{$9.87 \times 10^{3}$} & \multicolumn{3}{|c|}{$1.90 \times 10^{4}$} & \multicolumn{3}{|c|}{0.19} & \multicolumn{3}{|c|}{0.36} & $32 \%$ \\
\hline
\end{tabular}

Table 16. Pre- and post-test ${ }^{110 \mathrm{~m}} \mathrm{Ag} A_{i}$ and $\mathrm{A} / \mathrm{C}$ analysis for $1,300^{\circ} \mathrm{C}, 500 \mathrm{~h}$ FITT run

\begin{tabular}{|c|c|c|c|c|c|c|c|c|c|c|c|c|c|}
\hline \multirow{2}{*}{$\begin{array}{l}\text { Particle } \\
542-P 49 \\
\end{array}$} & \multicolumn{3}{|c|}{ Pre-test, $A_{i}\left({ }^{110 m} A g\right)$} & \multicolumn{3}{|c|}{ Post-test, $A_{i}\left({ }^{110 m} A g\right)$} & \multicolumn{3}{|c|}{$\begin{array}{c}\text { Pre-test } \\
\left({ }^{110 \mathrm{~m}} \mathrm{Ag} \mathrm{A} / \mathrm{C}\right)\end{array}$} & \multicolumn{3}{|c|}{$\begin{array}{c}\text { Post-test } \\
\left({ }^{110 \mathrm{~m}} \mathrm{Ag} \mathrm{A} / \mathrm{C}\right)\end{array}$} & \multirow{2}{*}{$\begin{array}{c}\% \text { change } \\
-36 \% \\
\end{array}$} \\
\hline & 8.78 & \pm & $1.32 \times 10^{4}$ & 5.63 & \pm & $1.72 \times 10^{4}$ & 1.59 & \pm & 0.24 & 1.02 & \pm & 0.31 & \\
\hline $542-\mathrm{P} 50$ & 6.96 & \pm & $1.13 \times 10^{4}$ & 6.99 & \pm & $1.57 \times 10^{4}$ & 1.26 & \pm & 0.20 & 1.26 & \pm & 0.28 & $1 \%$ \\
\hline $542-P 52$ & 2.95 & \pm & $0.96 \times 10^{4}$ & \multicolumn{3}{|c|}{$\leq 2.85 \times 10^{4}$} & 0.53 & \pm & 0.17 & \multicolumn{3}{|c|}{$\leq 0.51$} & $\geq-3 \%$ \\
\hline 542-P56 & 4.15 & \pm & $0.90 \times 10^{4}$ & \multicolumn{3}{|c|}{$\leq 2.88 \times 10^{4}$} & 0.75 & \pm & 0.16 & \multicolumn{3}{|c|}{$\leq 0.52$} & $\geq-31 \%$ \\
\hline $542-P 60$ & 2.99 & \pm & $0.89 \times 10^{4}$ & \multicolumn{3}{|c|}{$\leq 2.78 \times 10^{4}$} & 0.54 & \pm & 0.16 & \multicolumn{3}{|c|}{$\leq 0.50$} & $\geq-7 \%$ \\
\hline $542-P 64$ & 3.10 & \pm & $0.97 \times 10^{4}$ & \multicolumn{3}{|c|}{$\leq 3.07 \times 10^{4}$} & 0.56 & \pm & 0.17 & \multicolumn{3}{|c|}{$\leq 0.56$} & $\geq-1 \%$ \\
\hline 542-P65 & 3.83 & \pm & $1.16 \times 10^{4}$ & 2.98 & \pm & $1.27 \times 10^{4}$ & 0.69 & \pm & 0.21 & \multicolumn{3}{|c|}{$\leq 0.43$} & $\geq-39 \%$ \\
\hline $542-\mathrm{P} 67$ & \multicolumn{3}{|c|}{$\leq 1.86 \times 10^{4}$} & \multicolumn{3}{|c|}{$\leq 2.95 \times 10^{4}$} & \multicolumn{3}{|c|}{$\leq 0.57$} & \multicolumn{3}{|c|}{$\leq 0.53$} & NA \\
\hline 542-P68 & 5.88 & \pm & $1.14 \times 10^{4}$ & \multicolumn{3}{|c|}{$\leq 3.30 \times 10^{4}$} & 1.06 & \pm & 0.21 & \multicolumn{3}{|c|}{$\leq 0.60$} & $\geq-44 \%$ \\
\hline $542-P 69$ & 3.22 & \pm & $0.96 \times 10^{4}$ & \multicolumn{3}{|c|}{$\leq 3.01 \times 10^{4}$} & 0.58 & \pm & 0.17 & \multicolumn{3}{|c|}{$\leq 0.55$} & $\geq-6 \%$ \\
\hline Maximum & \multicolumn{3}{|c|}{$8.78 \times 10^{4}$} & \multicolumn{3}{|c|}{$6.99 \times 10^{4}$} & \multicolumn{3}{|c|}{1.59} & \multicolumn{3}{|c|}{1.26} & $1 \%$ \\
\hline Minimum & \multicolumn{3}{|c|}{$2.95 \times 10^{4}$} & \multicolumn{3}{|c|}{$2.98 \times 10^{4}$} & \multicolumn{3}{|c|}{$\leq 0.56$} & \multicolumn{3}{|c|}{$\leq 0.50$} & $\geq-44 \%$ \\
\hline Mean & \multicolumn{3}{|c|}{$4.55 \times 10^{4}$} & \multicolumn{3}{|c|}{$5.20 \times 10^{4}$} & \multicolumn{3}{|c|}{0.76} & \multicolumn{3}{|c|}{0.23} & $-18 \%$ \\
\hline Std Dev ( \pm ) & & & $9 \times 10^{4}$ & & 2.0 & & & .44 & & & .48 & & $18 \%$ \\
\hline
\end{tabular}

The ${ }^{110 \mathrm{~m}} \mathrm{Ag} \mathrm{A} / \mathrm{C}$ analysis is visualized in Figure 6 through Figure 9. In Figure 6 through Figure 9 the error bars represent one standard deviation in measured ${ }^{110 \mathrm{~m}} \mathrm{Ag} \mathrm{A} / \mathrm{C}$. Indication of release is observed in particles exposed to both 1,150 and $1,300^{\circ} \mathrm{C}$. Confident indication of release is noted for particles in which no overlap in the range of uncertainty is present between the pre- and post-test ${ }^{110 \mathrm{~m}} \mathrm{Ag} \mathrm{A} / \mathrm{C}$ data. Two classifications for identification of potential particle-level silver release are defined as "possible" and "likely" based on the uncertainty associated with the analysis. Particles classified as displaying "possible" silver release are particles which have post-test $\mathrm{A} / \mathrm{C}$ values outside of the range in uncertainty for the pretest values, but which have a range in uncertainty which overlaps the pre-test A/C. Particles classified as displaying "likely" silver release are particles which have post-test A/C values outside of the range in uncertainty for the pre-test $\mathrm{A} / \mathrm{C}$ and no overlap in reported uncertainty.

At $1,150^{\circ} \mathrm{C}, 100 \mathrm{~h}$, particle $542-\mathrm{P} 08$ shows possible release, with a $-24 \%$ reduction in post-test ${ }^{110 \mathrm{~m}} \mathrm{Ag}$ $\mathrm{A} / \mathrm{C}$; however, there is a slight overlap (equivalent to ${ }^{110 \mathrm{~m}} \mathrm{Ag} \mathrm{A} / \mathrm{C}$ of $\sim 0.06$ ) of the estimated uncertainty for the two measurements (Figure 6). Particle 542-P19, with a $-25 \%$ reduction in post-test ${ }^{110 \mathrm{~m}} \mathrm{Ag} \mathrm{A} / \mathrm{C}$, also suggests possible release as the measured ${ }^{110 \mathrm{~m}} \mathrm{Ag} \mathrm{A} / \mathrm{C}$ is outside of the measured uncertainty for the pre-test value. However, the degree of overlap in between the pre- and post-test is more significant 
relative to 542-P08 (equivalent to ${ }^{110 \mathrm{~m}} \mathrm{Ag} \mathrm{A} / \mathrm{C}$ of $\sim 0.10$ ). A stronger indication of release is observed at $1150^{\circ} \mathrm{C}, 500 \mathrm{~h}$, in which particles $542-\mathrm{P} 31$ and $542-\mathrm{P} 43$ show likely release with a post-test inventory outside the reported uncertainty, and no overlap. Particles 542-P44, and 542-P48 show a reduction in

${ }^{110 \mathrm{~m}} \mathrm{Ag} \mathrm{A} / \mathrm{C}$ of $-34 \%$, and $\geq-9 \%$, respectively with a slight overlap of reported uncertainty between the pre- and post-test analysis, suggesting possible release (Figure 7). Indication of release is more pronounced for the longer thermal exposure of $500 \mathrm{vs} .100 \mathrm{~h}$ at $1,150^{\circ} \mathrm{C}$.

The evidence for silver release is more pronounced for particles exposed to $1,300^{\circ} \mathrm{C}$ relative to the $1,150^{\circ} \mathrm{C}$ exposures. For the $1,300^{\circ} \mathrm{C}, 100 \mathrm{~h}$ exposure (Figure 8), particles 542-P04, 542-P15, 542-P24, and 542-P26 all show a likely release with reduction in ${ }^{110 \mathrm{~m}} \mathrm{Ag} \mathrm{A} / \mathrm{C}$ inventory outside of pre- and post-test uncertainty. Particles 542-P05, 542-P09, 542-P12, and 542-P27 show possible release, with a -17\%, $22 \%,-28 \%$ and $-31 \%$ reduction in post-test ${ }^{110 \mathrm{~m}} \mathrm{Ag} \mathrm{A} / \mathrm{C}$ respectively; however, there is a slight overlap of the estimated uncertainty for the two measurements. For the $1,300{ }^{\circ} \mathrm{C}, 500 \mathrm{~h}$ test (Figure 9) particles 542-P49, 542-P56, 542-P65, and 542-P68 showed likely release. The particles 542-P52, 542-P60, 542-P64, and 542-P69 all indicated a reduction in ${ }^{110 \mathrm{~m}} \mathrm{Ag} \mathrm{A} / \mathrm{C}$ and would fall under the "possible" release classification. However, the ${ }^{110 \mathrm{~m}} \mathrm{Ag} A_{i}$ is below the $\mathrm{L}_{\mathrm{Q}}$, so these particles can only be suggested as possible silver release. The numerous particles with ${ }^{110 \mathrm{~m}} \mathrm{Ag} A_{i}$ below $\mathrm{L}_{\mathrm{Q}}$ challenge the ability to assess a time dependence associated with observed release. However, the observed release behavior confirms that the release is particle dependent and is not necessarily uniform for all particles.

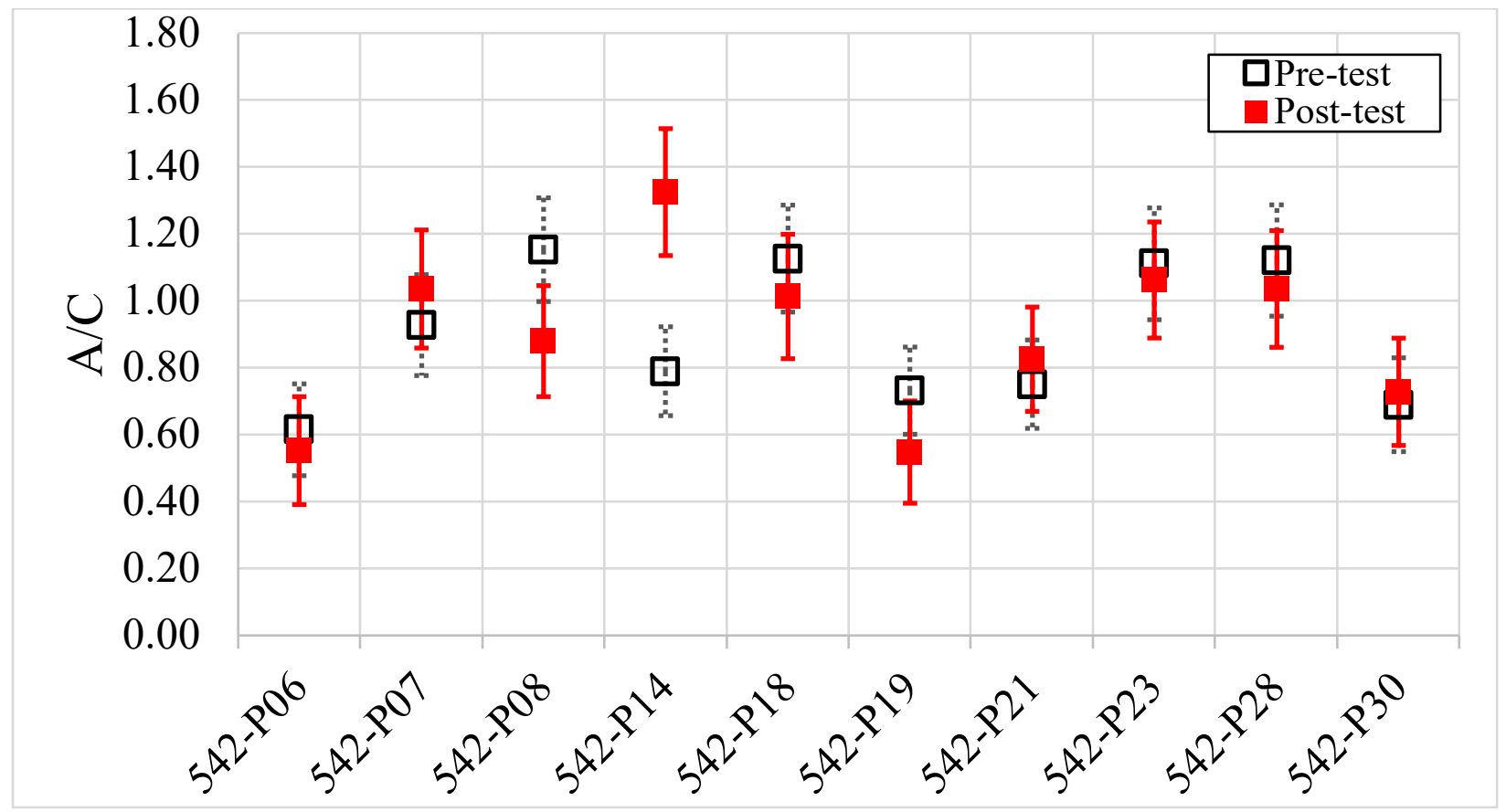

Figure 6. Pre- and post-test ${ }^{110 \mathrm{~m}} \mathrm{Ag} \mathrm{A} / \mathrm{C}$ for $1,150^{\circ} \mathrm{C}, 100 \mathrm{~h}$ exposure. 


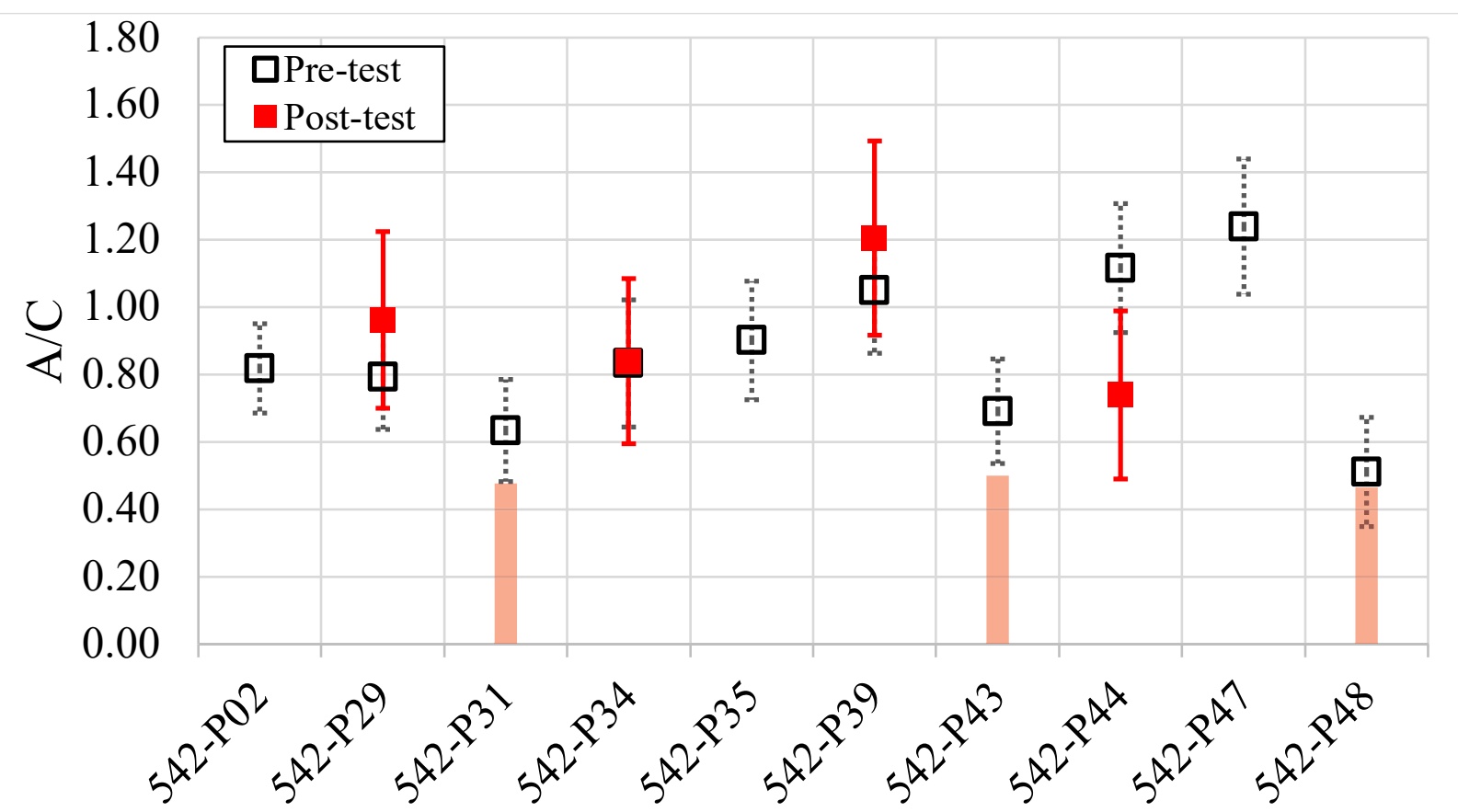

Figure 7. Pre- and post-test ${ }^{110 \mathrm{~m}} \mathrm{Ag} \mathrm{A} / \mathrm{C}$ for $1,150^{\circ} \mathrm{C}, 500 \mathrm{~h}$ exposure, red bars identify $\mathrm{L}_{\mathrm{Q}}$ range.

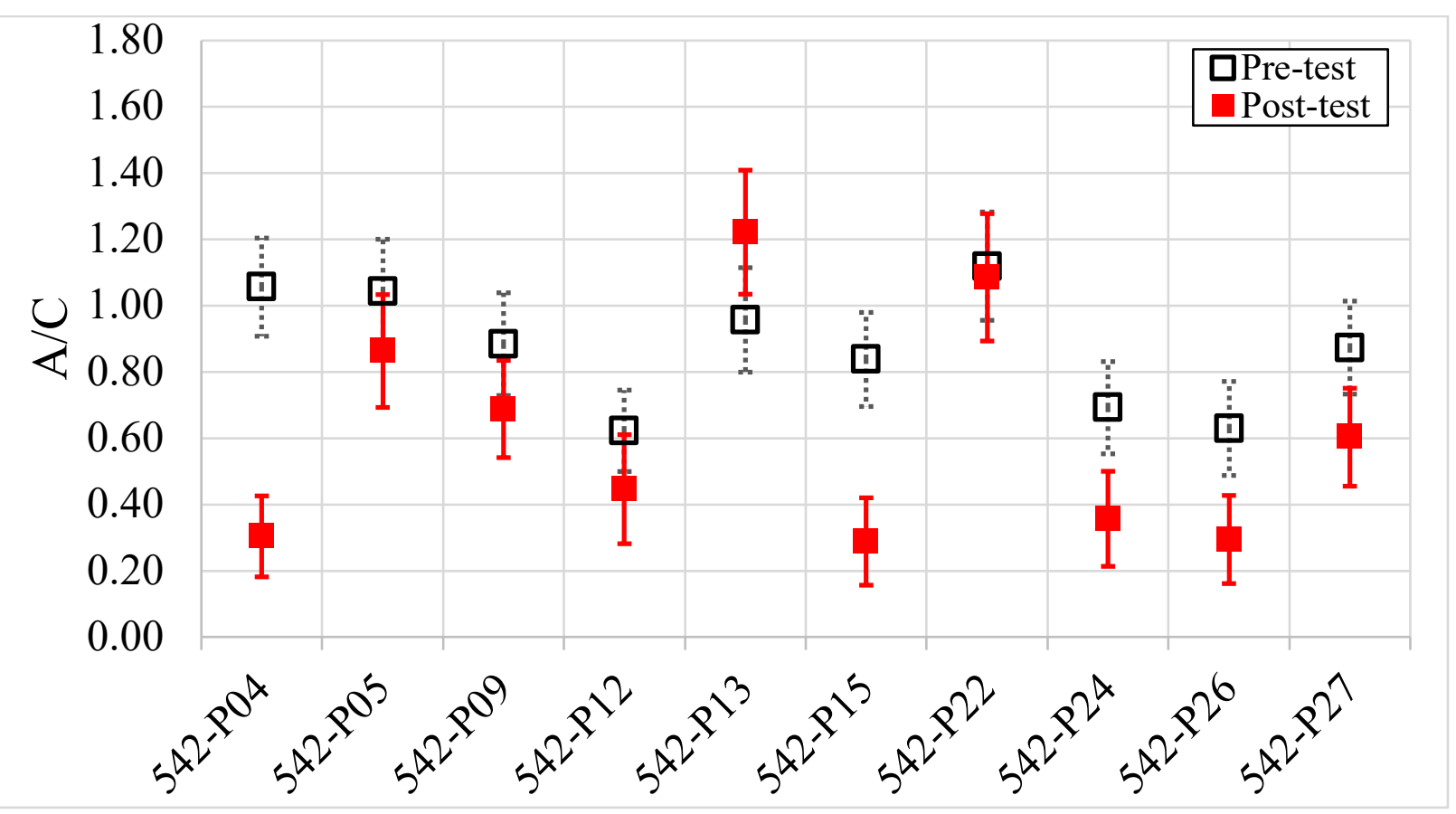

Figure 8. Pre- and post-test ${ }^{110 \mathrm{~m}} \mathrm{Ag} \mathrm{A} / \mathrm{C}$ for $1,300^{\circ} \mathrm{C}, 100 \mathrm{~h}$ exposure. 


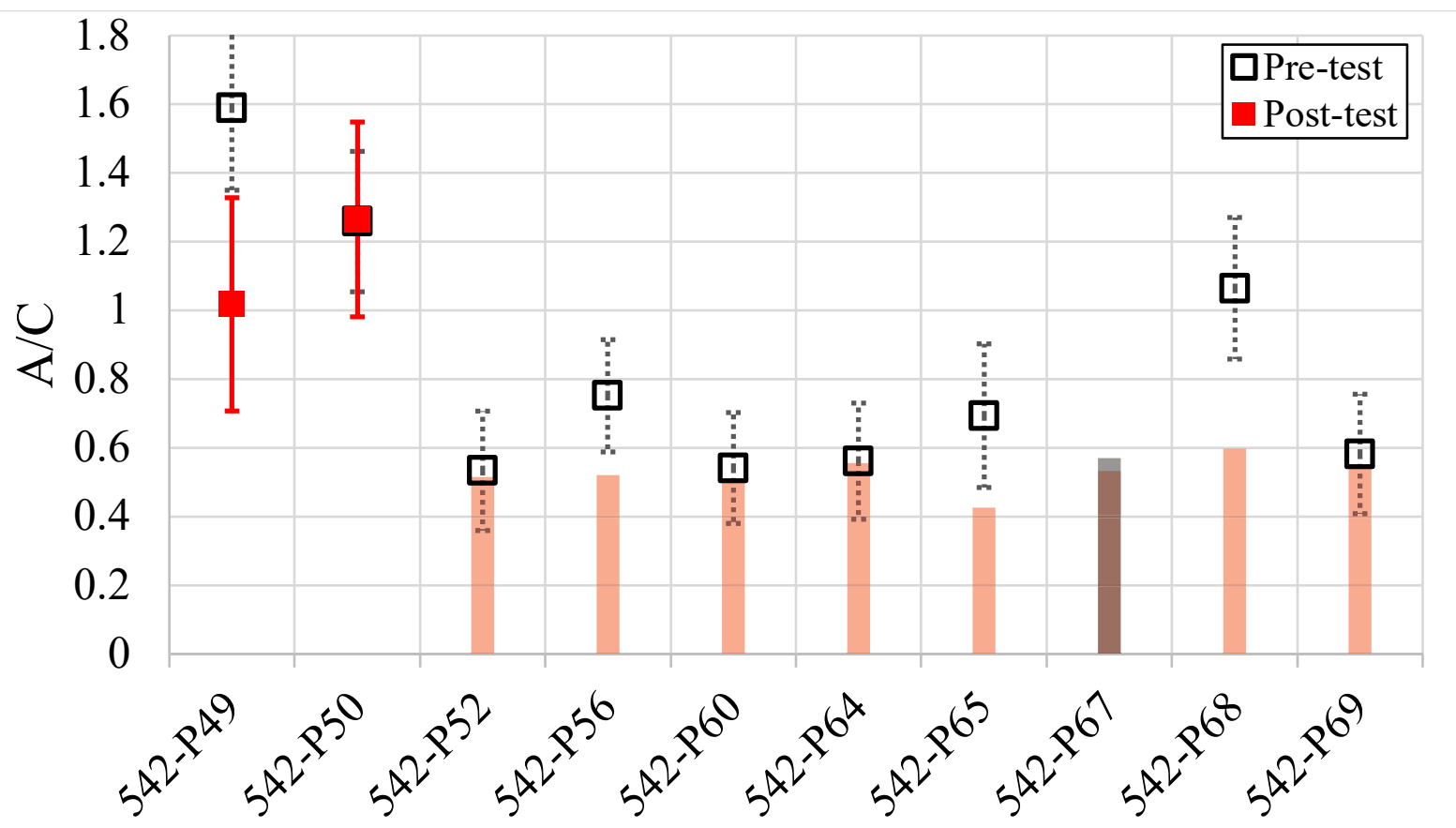

Figure 9. Pre- and post-test ${ }^{110 \mathrm{~m}} \mathrm{Ag} \mathrm{A} / \mathrm{C}$ for $1,300^{\circ} \mathrm{C}, 500 \mathrm{~h}$ exposure, black and red bars identify $\mathrm{L}_{\mathrm{Q}}$ range for pre-test and post-test respectively.

\subsection{PARTICLE FAILURE ANALYSIS}

The thermal exposures discussed in this report represent the first FITT runs performed on burnback irradiated TRISO particles. Particle failures were observed in select exposures. The number of particle failures for each run are listed in Table 17, and the failure rate is visualized by run sequence in Figure 10. Particle failure rates for the burnback exposures are much higher relative to integral compact tests, and mitigation strategies were explored during testing.

Table 17. Number of failed particles for each test condition

\begin{tabular}{ccccc}
\hline Temperature $\left({ }^{\circ} \mathbf{C}\right)$ & $\begin{array}{c}\text { T1 (h) } \mid \# \text { failed } \\
\text { particles }\end{array}$ & $\begin{array}{c}\text { T1 (h) } \mid \# \text { failed } \\
\text { particles }\end{array}$ & $\begin{array}{c}\text { T1 (h) } \mid \# \text { failed } \\
\text { particles }\end{array}$ & $\begin{array}{c}\text { T1 (h) } \mid \text { \# failed } \\
\text { particles }\end{array}$ \\
\hline $\mathbf{1 , 1 5 0}$ & $100 \mid 0$ & $500 \mid 3$ & $1,000^{* \wedge} \mid 2$ & $1,500^{\#} \mid 0$ \\
\hline $\mathbf{1 , 3 0 0}$ & $100 \mid 0$ & $500 \mid 0$ & $985^{\wedge * *} \mid 1$ & $1,500 \mid 0$ \\
\hline $\mathbf{1 , 6 0 0}$ & $84^{*} \mid 4$ & $500 \mid 2$ & $1,000^{*} \mid 10$ & $1,500^{* *} \mid 10$ \\
\hline
\end{tabular}

Strike through indicates no recoverable particles were found after exposure

$\wedge$ indicates unplanned power outages

* indicates planned ventilation outage with controlled cooldown

* indicates number of thermocouple failures 


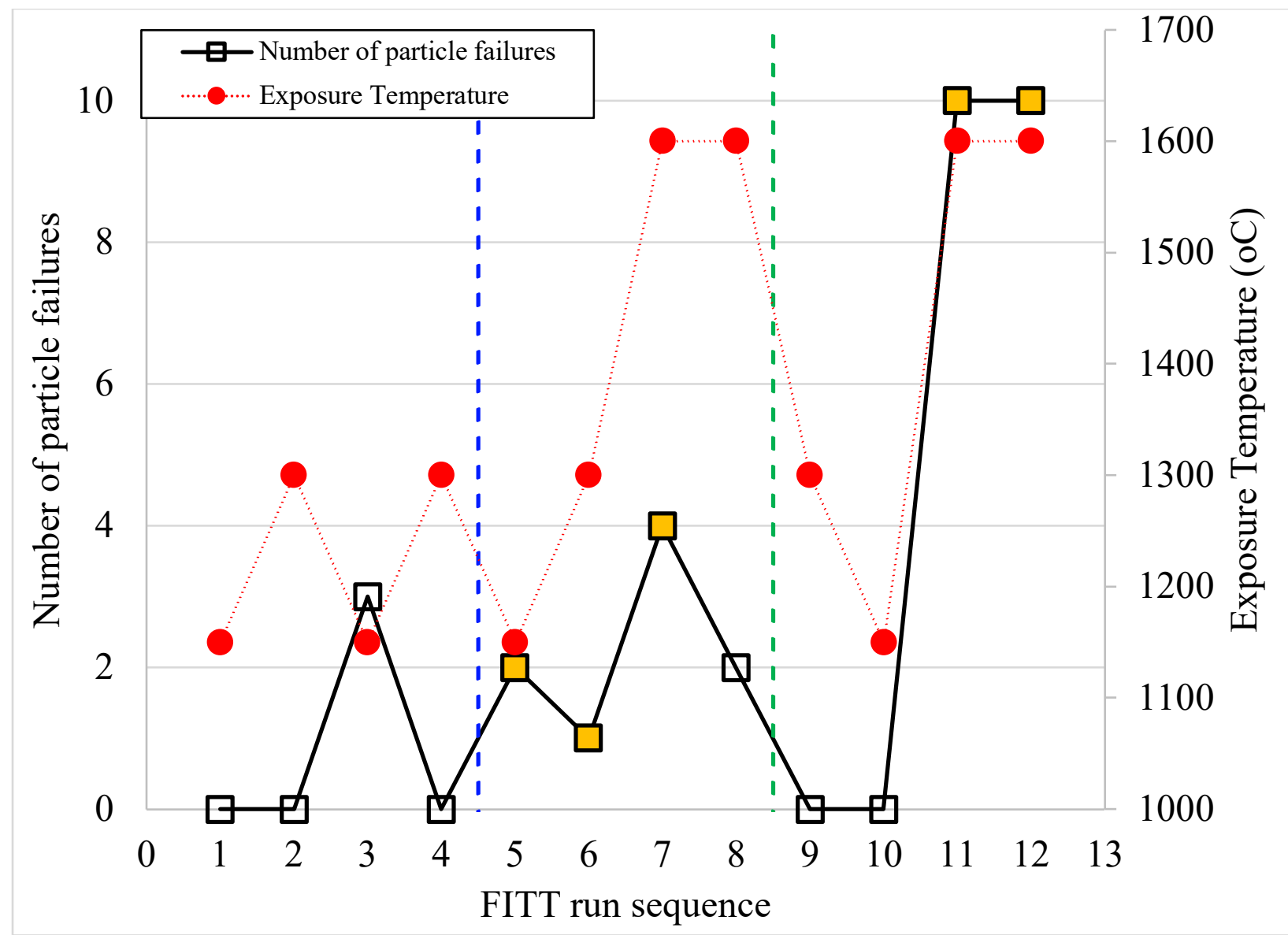

Figure 10. Particle failures as function of run sequence, orange filled data points represent tests with thermocouple failures.

Particle failures were observed in the third FITT exposure of $1,150^{\circ} \mathrm{C}$ and $500 \mathrm{~h}$. This resulted in an combined $\sim 10 \%$ failure rate for the first three tests. These test conditions were relatively low temperature, and particle failure was atypical of those observed in loose particle testing at $1,800^{\circ} \mathrm{C}$ for $650 \mathrm{~h}$, with a failure rate of $\sim 5 \%$ at $300 \mathrm{~h}$ and $\sim 7 \%$ at $650 \mathrm{~h}$ (Hunn et al. 2015b). The observed failure rates at such low temperatures was concerning, and the working hypothesis was that the failures may be due to excessive handling after deconsolidation leach-burn-leach, and transfer out of the cell to the FITT systems. Incremental improvements were made to the particle handling after this early observation; including using plastic containers and vacuum tweezers to handle particles instead of aluminum canisters and standard steel tweezers. The concern was that aluminum could transfer metal to the particle surface, leading to local corrosion at temperature, and the tweezers may impart mechanical damage to the particles. Other changes include the use of a particle loading guide system to nest over the graphite holder to allow for easy loading of each particle, as well as antistatic measures to ensure that particles were not lost during loading. Figure 11 shows the particle loading system used to improve particle loading. Again, these measures were implemented to reduce handling. The subsequent run of $1,300^{\circ} \mathrm{C}$ at $500 \mathrm{~h}$ saw a reduction in particle failure rate relative to the prior run. 


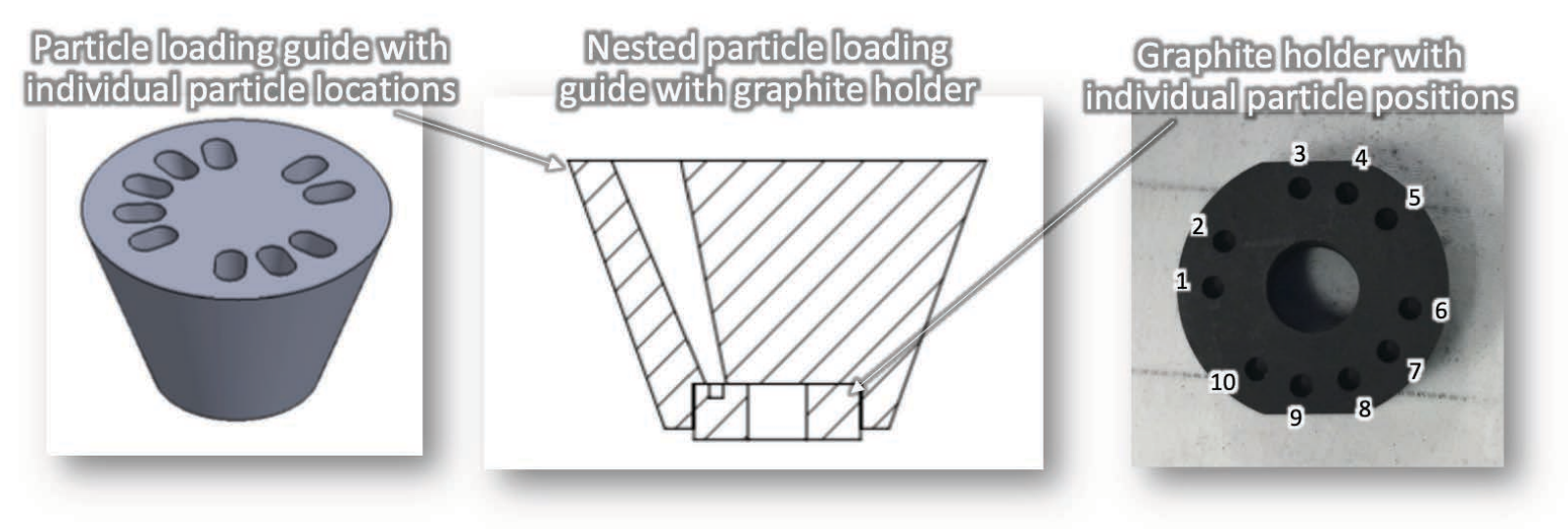

Figure 11. Schematic of particle loading guide system which nests over the graphite holder

However, particle failures were not eliminated after this process improvement. For the 1,150 and $1,300^{\circ} \mathrm{C}$ runs at $1,000 \mathrm{~h}$ (FITT sequence run 5 and 6$)$ and $1,600^{\circ} \mathrm{C}$ at $100 \mathrm{~h}(84 \mathrm{~h}$ final elapsed time, FITT sequence run 7) exposures, thermocouple failures were observed mid run and these failures were assumed to be related to the particles to being subjected to thermal shock due to rapid cooldown. This may have compromised the particles upon resuming the testing. To limit thermocouple failures, the manufacturer supplied Type B thermocouples with exposed beads were replaced with ceramic-sealed thermocouples from Omega. This resulted in no thermocouple failures for longer term tests at 1,150 and $1,300^{\circ} \mathrm{C}$ at $1,500 \mathrm{~h}$ and $1600^{\circ} \mathrm{C}$ at $500 \mathrm{~h}$.

Post-test optical image evaluation (Figure 12) of the $1,600^{\circ} \mathrm{C}, 84 \mathrm{~h}$ exposure suggested that the particles failed early in the run, as little material was left remaining, and the particles were not intact: failure during the rapid cooldown would be expected to limit volatilization of the kernel and gross degradation of other particle components. The results from the $1,600^{\circ} \mathrm{C} 84 \mathrm{~h}$ exposure suggest that there was possible failure related to the ramp rate of $10^{\circ} \mathrm{C} / \mathrm{min}$. This is further supported by the observation that the intact particles look similar to particles from long term exposures $\left(1,300^{\circ} \mathrm{C}, 1,500 \mathrm{~h}\right)$ where no abnormal behavior was present and all particles remained intact, suggesting no deleterious impacts from unexpected oxygen ingress. While the $10^{\circ} \mathrm{C} / \mathrm{min}$ ramp rate was assumed to be sufficiently slow based on prior rapid cooling rates observed during rapid cooldown events in the CCCTF which resulted in no particle failures, the individual particle and burnback nature of the loose particle testing may result in more vulnerable particles. To mitigate the possible risk due to ramp rate, a slower ramp and cooling rate of $5^{\circ} \mathrm{C} / \mathrm{min}$ was implemented, along with a hold at $250^{\circ} \mathrm{C}$ to drive out any possible moisture. The subsequent tests at 1,150 and $1,300^{\circ} \mathrm{C}$ for $1,500 \mathrm{~h}$ resulted in zero particle failures. 


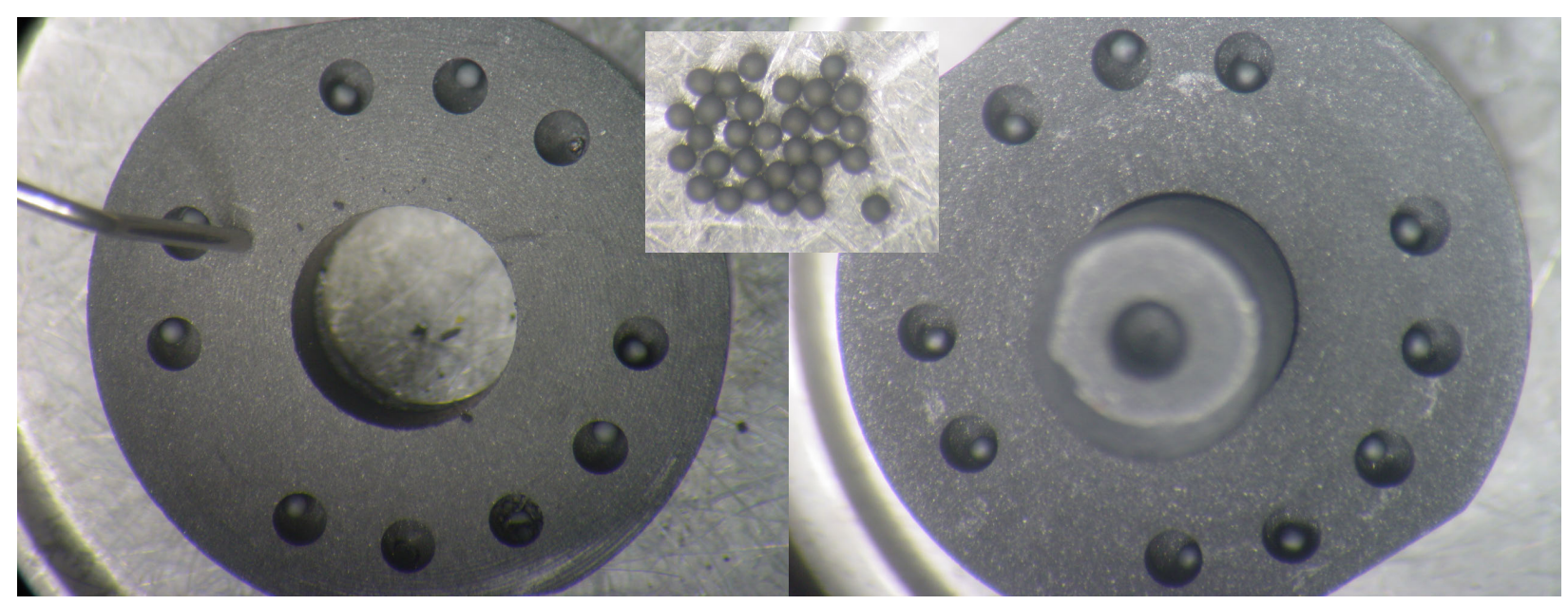

Figure 12. Photograph of post-test particles from $1,600^{\circ} \mathrm{C}, 84 \mathrm{~h}$ run (left) and $1,300^{\circ} \mathrm{C}, 1,500 \mathrm{~h}$ run (right) with inset showing as-irradiated burnback particles.

The total failure of the $1,600^{\circ} \mathrm{C}, 1,000 \mathrm{~h}$ and $1,500 \mathrm{~h}$ tests (run sequence 11 and 12 in Figure 10) was due to observed primary tube failures and subsequent oxidation at $1,600^{\circ} \mathrm{C}$, as noted earlier. The tube failure was speculated to be brought on due to rapid cooldown from $1,600^{\circ} \mathrm{C}\left(>50^{\circ} \mathrm{C} / \mathrm{min}\right)$ due to loss of power triggered by the safety shutoff to the system associated with thermocouple failure. The thermocouples used in these tests were already subjected to $1,500 \mathrm{~h}$ of operation at $1,150^{\circ} \mathrm{C}$ and $1,300^{\circ} \mathrm{C}$ from prior test sequences, which may have led to early thermocouple failure after $\sim 400-560 \mathrm{~h}$. However, this operational experience indicates that thermocouple failures are more prevalent at $1,600^{\circ} \mathrm{C}$, even for thermocouples rated to $1,700^{\circ} \mathrm{C}$

The thermocouple failures and rapid cooldown from $1,600^{\circ} \mathrm{C}$ likely caused cracking of the primary ceramic furnace tube. These cracks were not observed upon restarting the test during the pre-run pumpand-purge cycle and vacuum check. They likely occurred during the ramp back up to temperature. Evidence of primary tube cracking was noted at the end of both runs due to the rapid loss of flow gas upon cooldown and contamination in the furnace internals at the end of the run. The small cracks were a likely source of oxygen ingress and oxidation. The overpressurization of the system was intended to mitigate this ingress but was not sufficient to stop all oxygen ingress. The particles were exposed to temperature for $\sim 1,100$ and $\sim 440 \mathrm{~h}$ in the thermally shocked tubes, which displayed evidence of cracking and air ingress. This was the source of the complete particle failure.

\section{DISCUSSION}

No obvious indication of additional release of ${ }^{106} \mathrm{Ru},{ }^{125} \mathrm{Sb},{ }^{134} \mathrm{Cs},{ }^{137} \mathrm{Cs}$, and ${ }^{144} \mathrm{Ce}$ was observed over the conditions explored. This was not unexpected for ${ }^{106} \mathrm{Ru},{ }^{125} \mathrm{Sb},{ }^{134} \mathrm{Cs},{ }^{137} \mathrm{Cs}$, and ${ }^{144} \mathrm{Ce}$, which are well retained in intact particles during safety testing at elevated temperature and do not show indication of bimodal release behaviors during transient or stepwise safety testing like silver. Though some particles did show a reduction in their inventory for these fission products, the magnitude was not significant relative to the measurement uncertainty and release could not be confirmed nor disproved.

Uniform release of ${ }^{154} \mathrm{Eu}$ was not observed in this work. Europium has been observed to release from intact particles in pile for high-temperature compacts (Hunn et al. 2016) and has been suggested to be released from intact particles during safety testing at $1,800^{\circ} \mathrm{C}$ (Morris et al. 2014), but complication with slow release from the matrix has challenged direct observation. The prior work by Bullock suggests 
uniform release of ${ }^{154} \mathrm{Eu}$ during individual particle thermal exposures over $1200-1500^{\circ} \mathrm{C}$ up to $10,000 \mathrm{~h}$ (Bullock 1984). For UCO TRISO fuel, ${ }^{154}$ Eu breakthrough at $1,200^{\circ} \mathrm{C}$ was observed after $\sim 5,000-8,000 \mathrm{~h}$; as such, no release would be expected to be observed in for the $1,150^{\circ} \mathrm{C}$ conditions explored here.

Breakthrough was observed at $1350-1500^{\circ} \mathrm{C}$ by Bullock on the order of $\sim 500 \mathrm{~h}$. Therefore, observation of uniform release would not be unexpected for the 1,300 and $1,600^{\circ} \mathrm{C}$ exposures at $500 \mathrm{~h}$. However, the uncertainty in the ${ }^{154} \mathrm{Eu}$ activity analysis in this work was on the order of $\pm 6 \%$, based on the maximum observed increase $(+)$ change in ${ }^{154} \mathrm{Eu}$ inventory being $+6 \%$, this suggests that release fractions greater than this are needed to obseved active release using the analysis methods developed for FITT experiments. In Bullock's work, release fractions on the order to $10 \%$ were not observed until $\sim 5,000 \mathrm{~h}$ at $1,350^{\circ} \mathrm{C}$ and $\sim 3,000 \mathrm{~h}$ for $1,500^{\circ} \mathrm{C}$, which would support the lack of observed uniform ${ }^{154} \mathrm{Eu}$ release in the FITT tests. Ultimately, longer exposures are needed to confirm the through-layer release and kinetics from AGR pedigree UCO TRISO fuel to observe and support expectations of uniform ${ }^{154} \mathrm{Eu}$ release by classical diffusion mechanisms, as suggested by Bullock (Bullock, 1984).

Loose particle testing of AGR-1 particles at $1,800^{\circ} \mathrm{C}, 650 \mathrm{~h}$ showed average ${ }^{154} \mathrm{Eu}$ release of $\sim 11 \pm 7 \%$ after exposure with some particles not indicating any release at all. During this experiment 8 of the 70 intact particles ( $\sim 11 \%$ of the particles) released greater than $20 \%$ of their inventory. This confirms particle-to-particle variability where some particles more readily release ${ }^{154} \mathrm{Eu}$ compared to others (Hunn et al. 2015b). The particle-to-particle specific release behavior in the FITT exposures suggest similar behaviors. Indication of release was observed across all temperatures explored in the FITT exposures with 5 of the 87 quality, intact particles suggesting release and 5 of the 87 showing release percentages outside of one standard deviation of the mean. The population of the particles which displayed "greater" release is lower than the $1,800^{\circ} \mathrm{C}, 650 \mathrm{~h}$ loose particle safety test, however, this is not surprising as the ultimate temperatures were much lower. Overall the observations from the FITT testing suggest ${ }^{154} \mathrm{Eu}$ release may be active out-of-pile below at $<1600^{\circ} \mathrm{C}$ and more pronounced in select particles.

Release of ${ }^{110 \mathrm{~m}} \mathrm{Ag}$ was indicated during FITT runs at $1,150-1,300^{\circ} \mathrm{C}$. The release behavior was nonuniform, meaning that there was a large particle-to-particle variation in release behavior. This observation of particle-to-particle variability is consistent with prior reported silver release behaviors. The particle-to-particle variation was observed in the loose particle testing of AGR-1 particles exposed to $1,800^{\circ} \mathrm{C}, 650 \mathrm{~h}$. In that test 1 of the 70 intact particles retained most of it inventory while 4 of the 70 released $15-51 \%$ of their inventory and the remaining particles released $>61 \%$ of their inventory (Below $\mathrm{L}_{\mathrm{Q}}$ ) (Hunn et al, 2015b). The primary variation is the temperatures at which this particle specific release occurs which is $500^{\circ} \mathrm{C}$ greater than in the FITT tests. The particle specific release observation was consistent with previously reported results by Bullock, which showed a subset of TRISO particles releasing a majority of their inventory (45-100\%), while some particles retained all of their inventory ( $0 \%$ release) (Bullock 1984). These observations were made over a variation in kernel and TRISO architectures but over a similar temperature range $1,200-1,500^{\circ} \mathrm{C}$ compared to the temperatures in this experiment $\left(1,150-1,300^{\circ} \mathrm{C}\right)$, thus supporting the observation of additional release over the temperatures explored here. Breakthrough times for silver were less than $\sim 500 \mathrm{~h}$ in the Bullock study at $1,350^{\circ} \mathrm{C}$. The particle-to-particle variation suggests that in pile conditions or structural variations lead to nonuniform release behavior since the particles are exposed to identical thermal condition during FITT. PIE of AGR TRISO fuel suggests that the variation in irradiation temperature across the compact influences a particle response during safety or margin testing (Gerczak et al. 2020a, Gerczak et al. 2020b). The observed nonuniform release behavior would suggest a possible connection to in pile-irradiation conditions impacting observed silver release at $1,150-1,300^{\circ} \mathrm{C}$.

The likely ${ }^{110 \mathrm{~m}} \mathrm{Ag}$ release appears to be more pronounced for the longer exposure at $1,150^{\circ} \mathrm{C}$, suggesting that a kinetic process was responsible for release. A similar statement regarding release cannot be made for $1,300^{\circ} \mathrm{C}$, as the release was similar in both the $100 \mathrm{~h}$ test and the $500 \mathrm{~h}$ test, although the latter was challenged by increased uncertainty in the silver activity analysis. Comparing the isochronal 1,150 and 
$1,300^{\circ} \mathrm{C} 100 \mathrm{~h}$ exposures, it appears that the likely silver release was more prevalent at $1,300^{\circ} \mathrm{C}$. At $1,150^{\circ} \mathrm{C}$ for $100 \mathrm{~h}, 2$ of 10 particles indicated possible release of silver and showed a mean percentage change in silver activity post-test of $+1 \%$ for all particles, whereas at $1,300^{\circ} \mathrm{C}$ for $100 \mathrm{~h}, 4$ of 9 relevant particles indicated likely release of silver and showed a mean percentage change in silver activity posttest of $-31 \%$ for all particles. This supports the observation that release is more pronounced at $1,300^{\circ} \mathrm{C}$ than at $1150^{\circ} \mathrm{C}$. This agrees with the observation from Bullock, which showed lower release at $1,200^{\circ} \mathrm{C}$ compared to $1,350^{\circ} \mathrm{C}$ although it would seem to contradict the observed release behaviors from stepwise and transient testing, which indicate greater release rates at temperatures closer to $1,150^{\circ} \mathrm{C}$ compared to $1,300^{\circ} \mathrm{C}$. These tests are integral in nature and require multiple active transport pathways for silver to reach the deposition cup and measured release rate. This analysis may be complicated by lower temperatures, which may cause some discrepancies in release rate comparisons across different temperatures (Hunn et al. 2015a). Regardless, the FITT testing shows that ${ }^{110 \mathrm{~m}} \mathrm{Ag}$ release is likely active from isolated burnback particles below the standard safety testing temperatures, thus providing potential support for a bimodal release behavior and multiple active diffusion mechanisms supporting silver diffusion through intact TRISO SiC.

Multiple lessons were learned during implementation of the FITT experiments which can be applied to refine and improve operation for future experiments. The analysis of ${ }^{110 \mathrm{~m}} \mathrm{Ag}$ release requires that FITT exposure experiments be performed early in the PIE effort, when the fuel has undergone fewer ${ }^{110 \mathrm{~m}} \mathrm{Ag}$ half-lives. The impact of decay on the assessment of ${ }^{110 \mathrm{~m}} \mathrm{Ag}$ activity was clearly observed, as the reduction in activity did not allow for assessment of ${ }^{110 \mathrm{~m}} \mathrm{Ag}$ activity beyond the first four FITT exposures. Analysis of ${ }^{110 \mathrm{~m}} \mathrm{Ag}$ release earlier in the PIE process will reduce the relative uncertainty in the measurements and will provide more confidence in confirming silver release and bimodal release behavior. The PIE of AGR-5/6/7 is planned to commence in 2021, and future FITT exposures should start with an isochronal comparison across the three temperatures explored here. Furthermore, the FITT has demonstrated the ability to support a mechanistic understanding of fission product release building upon the engineering level release observed in CCCTF and FACS safety testing. Specifically, compact level safety testing intends to obtain performance data to support qualification and licensing over a statistically relevant number of particles. The intention of FITT is to allow for expanded conditions to be explored based on safety testing analysis allowing for potential insight into release mechanisms through particle level analysis and diffusion kinetics based on break through times to support modeling which expanded test conditions may resolve.

Changes to the experimental approach showed improvements in lowering the relative failure rate in the final testing approach; excluding the long-term $1,600^{\circ} \mathrm{C}$ conditions. The final testing approach (handling and ramp and cooling profiles) should be implemented for future runs, with additional adaptations to limit thermocouple failures and subsequent oxidation risk at high-temperature runs (e.g., $1,600^{\circ} \mathrm{C}$ ). The changes that should be adapted based on the current state of knowledge are (1) to replace thermocouples prior to each run, and (2) to replace the primary ceramic furnace tube after any rapid cooldown, such as a power failure or thermocouple failure. Replacing the thermocouples should result in longer uninterrupted operation, and replacing the furnace tube will limit any risk due to tube failure.

\section{SUMMARY}

A new furnace design - the FITT - was installed and tested at ORNL for exploring the fission product release behavior beyond the standard safety testing schedule. In total, two FITT systems were implemented, and operational experience was leveraged to improve testing approaches. The system has demonstrated a testing capability of 1,150 and $1300^{\circ} \mathrm{C}$ for up to $1,500 \mathrm{~h}$, and $1,600^{\circ} \mathrm{C}$ for $500 \mathrm{~h}$. Lessons learned will be implemented in future tests to explore longer exposure times at $1,600^{\circ} \mathrm{C}$. 
No clear evidence of uniform through-layer release of the fission products ${ }^{106} \mathrm{Ru},{ }^{125} \mathrm{Sb},{ }^{134} \mathrm{Cs},{ }^{137} \mathrm{Cs},{ }^{144} \mathrm{Ce}$, and ${ }^{154} \mathrm{Eu}$ was observed while possible particle-to-particle variability associated with ${ }^{154} \mathrm{Eu}$ release was suggested in two outlier particles. This was not unexpected based on reported release behaviors for these fission products over the conditions explored. Nonuniform release was observed for ${ }^{110 \mathrm{~m}} \mathrm{Ag}$ at 1,150 and $1,300^{\circ} \mathrm{C}$, providing additional supporting evidence of two active release mechanisms at low and high temperatures. The particle-to-particle variation also indicates a likely relationship with different in-pile conditions experienced by different particles. Further exploration of an isochronal comparison is needed to explicitly observe the bimodal release behavior. 


\section{REFERENCES}

Baldwin, Charles A., John D. Hunn, Robert N. Morris, Fred C. Montgomery, Chinthaka M. Silva, and Paul A. Demkowicz. 2012. "First Elevated Temperature Performance Testing of Coated Particle Fuel Compacts from the AGR-1 Irradiation Experiment." Proc. 6th International Topical Meeting on High Temperature Reactor Technology (HTR-2012). Tokyo, October 28-November 1, 2012. Also published in Nucl. Eng. Des. 271: 131-141.

Bullock, R. E. 1984. "Fission-Product Release During Postirradiation Annealing of Several Types of Coated Fuel Particle.” J. Nucl. Mater. 125: 304-319.

Demkowicz, Paul A., Edward L. Reber, Dawn M. Scates, Les Scott, and Blaise P. Collin. 2015a. "First High Temperature Safety Tests of AGR-1 TRISO Fuel with the Fuel Accident Condition Simulator (FACS) Furnace." J. Nucl. Mater. 464: 320-330.

Demkowicz, Paul A., John D. Hunn, Robert N. Morris, Isabella J. van Rooyen, Tyler J. Gerczak, Jason M. Harp, and Scott A. Ploger. 2015b. AGR-1 Post Irradiation Examination Final Report. INL/EXT15-36407, Revision 0. Idaho Falls: Idaho National Laboratory.

Demkowicz, Paul A., John D. Hunn, David A. Petti, and Robert N. Morris. 2016. "Key results from irradiation and post-irradiation examination of AGR-1 UCO TRISO fuel." Proc. 8th International Topical Meeting on High Temperature Reactor Technology (HTR-2016). Las Vegas, November 610, 2016. Also published in Nucl. Eng. Des. 329: 102-109.

Gerczak, Tyler J., Hunn, John D., Lowden, Richard A., Allen, Todd R., 2016. "SiC Layer Microstructure in AGR-1 and AGR-2 TRISO Fuel Particles and the Influence of its Variation on the Effective Diffusion of Key Fission Products." J. Nucl. Mater. 480 (2016). doi:10.1016/j.jnucmat.2016.08.011.

Gerczak, Tyler J., John D. Hunn, Robert N. Morris, Fred C. Montgomery, Darren J. Skitt, Charles A. Baldwin, John A. Dyer, and Brian D. Eckhart. 2018. "Analysis of Fission Product Distribution and Composition in the TRISO Layers of AGR-2 Fuel." Proc. 9th International Topical Meeting on High Temperature Reactor Technology (HTR-2018). Warsaw, October 8-10, 2018.

Gerczak, Tyler J., Rachel L. Seibert, John D. Hunn, Charles A. Baldwin, Fred C. Montgomery, and Robert N. Morris. 2020a. "Redistribution of Radionuclides in Irradiated AGR-1 UCO TRISO Fuel after $1800^{\circ} \mathrm{C}$ Safety Testing." J. Nucl. Mater. 542: 152453.

Hawkes, Grant L. 2014. AGR-2 Daily As-Run Thermal Analyses. INL/ECAR-2476, Revision 1. Idaho Falls: Idaho National Laboratory.

Hunn, John D., Robert N. Morris, Charles A. Baldwin, Fred C. Montgomery, Chinthaka M. Silva, and Tyler J. Gerczak. 2013. AGR-1 Irradiated Compact 4-4-2 PIE Report: Evaluation of As-Irradiated Fuel Performance with Leach Burn Leach, IMGA, Materialography, and X-ray Tomography. ORNL/TM-2013/236, Revision 0. Oak Ridge: Oak Ridge National Laboratory.

Hunn, John D., Robert N. Morris, Charles A. Baldwin, Fred C. Montgomery, Tyler J. Gerczak, $2015 a$. PIE on Safety-Tested AGR-1 Compact 4-2-2. ORNL/TM-2015/033, Revision 0. Oak Ridge: Oak Ridge National Laboratory. 
Hunn, John D., Robert N. Morris, Charles A. Baldwin, Fred C. Montgomery, and Tyler J. Gerczak, 2015b. PIE on Safety-Tested Loose Particles from AGR-1 Compact 4-4-2. ORNL/TM-2015/161, Revision 0. Oak Ridge: Oak Ridge National Laboratory.

Hunn, John D., Charles A. Baldwin, Fred C. Montgomery, Tyler J. Gerczak, Robert N. Morris, Grant W. Helmreich, Paul A. Demkowicz, Jason M. Harp, and John D. Stempien. 2016. "Initial Examination of Fuel Compacts and TRISO Particles from the US AGR-2 Irradiation Test." Proc. 8th International Topical Meeting on High Temperature Reactor Technology (HTR-2016). Las Vegas, November 610, 2016. Also published in Nucl. Eng. Des. 329: 89-101.

Hunn, John D., Robert N. Morris, Fred C. Montgomery, Tyler J. Gerczak, Darren J. Skitt, Charles A. Baldwin, John A. Dyer, Grant W. Helmreich, Brian D. Eckhart, Zachary M. Burns, Paul A. Demkowicz, and John D. Stempien. 2018a. "Post-Irradiation Examination and Safety Testing of US AGR-2 Irradiation Test Compacts." Proc. 9th International Topical Meeting on High Temperature Reactor Technology (HTR-2018). Warsaw, October 8-10, 2018.

Hunn, John D., Tyler J. Gerczak, Fred C. Montgomery, Darren J. Skitt, Charles A. Baldwin, Grant W. Helmreich, Brian D. Eckhart, and John A. Dyer. 2018b. AGR-2 As-Irradiated UCO Compact 5-4-2 PIE Report. ORNL/TM-2018/863, Revision 0. Oak Ridge: Oak Ridge National Laboratory.

Hunn, John D., Robert N. Morris, and Zachary M. Burns. 2019. Transient Temperature Safety Test of AGR-2 UCO Compacts 5-1-1, 5-1-2, and 5-1-3. ORNL/TM-2019/1292, Revision 0. Oak Ridge: Oak Ridge National Laboratory.

Hunn, John D., Tyler J. Gerczak, Robert N. Morris, Fred C. Montgomery, Darren J. Skitt, Grant W. Helmreich, Brian D. Eckhart, and Charles A. Baldwin. 2020. Destructive PIE and Safety Testing of Six AGR-2 UO $\mathrm{U}_{2}$ Capsule 3 Compacts. ORNL/TM-2020/1612, Revision 0. Oak Ridge: Oak Ridge National Laboratory.

IAEA, 1997. Fuel Performance and Fission Product Behaviour in Gas Cooled Reactors. IAEATECDOC-978, International Atomic Energy Agency, Vienna.

Morris, Robert N., Paul A. Demkowicz, John D. Hunn, Charles A. Baldwin, and Edward L. Reber. 2014. "Performance of AGR-1 High Temperature Reactor Fuel During Post-Irradiation Heating Tests." Proc. 7th International Topical Meeting on High Temperature Reactor Technology (HTR-2014). Weihai, October 27-31, 2014. Also published in Nucl. Eng. Des. 306: 24-35.

Morris, Robert N., John D. Hunn, Charles A. Baldwin, Fred C. Montgomery, Tyler J. Gerczak, and Paul A. Demkowicz. 2016. "Initial Results from Safety Testing of US AGR-2 Irradiation Test Fuel." Proc. 8th International Topical Meeting on High Temperature Reactor Technology (HTR-2016). Las Vegas, November 6-10, 2016. Also published in Nucl. Eng. Design 329: 124-133.

Opila, Elizabeth. 1995. "Influence of Alumina Reaction Tube Impurities on the Oxidation of ChemicallyVapor Deposited Silicon Carbide.” J. Am. Ceram. Soc. 78: 1107-1110.

Petti, David, John Maki, John D. Hunn, Pete Pappano, Charles Barnes, John Saurwein, Scott Nagley, Jim Kendall, and Richard Hobbins. 2010. "The DOE Advanced Gas Reactor Fuel Development and Qualification Program.” JOM. 62: 62-66. 
Petti, David A., John T. Maki, Jacopo Buongiorno, Richard R. Hobbins, and Gregory K. Miller. 2002. Key Differences in the Fabrication, Irradiation and Safety Testing of U.S. and German TRISO-coated Particle Fuel and Their Implications on Fuel Performance. INEEL/EXT-02-00300, Revision 0. Idaho Falls: Idaho National Laboratory.

Nabielek, Heinz, P. E. Brown, and Peter B. Offerman. 1977. "Silver Release from Coated Particle Fuel." Nucl. Tech. 35: 483-493.

Stempien John D. Paul A. Demkowicz, Edward L. Reber, and Cad L. Christensen. 2016. "HighTemperature Safety Testing of Irradiated AGR-1 TRISO Fuel. ” Proc. 8th International Topical Meeting on High Temperature Reactor Technology (HTR-2016). Las Vegas, November 6-10, 2016.

Sterbentz, James W. 2014. JMOCUP As-Run Daily Depletion Calculation for the AGR-2 Experiment in the ATR B-12 Position. ECAR-2066, Revision 2. Idaho Falls: Idaho National Laboratory. 